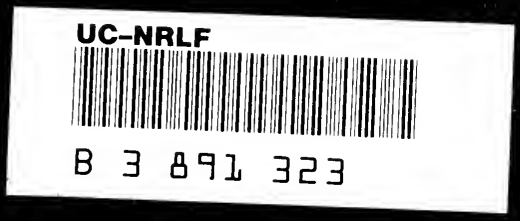




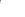


• 

This is an authorized facsimile and was produced oy microfilm-xerography in 1973 by University Microfilms, Xerox Company, Ann Arbor, Michigan, U.S.A. 
Spagnuoli, Baptista

\section{THE ECLOGUES OF}

\section{BAPTISTA MANTUANUS}

EDITED, WITH INTRODUCTION AND NOTES, BY

WILFRED P."MUSTARD, Ph.D. COLLEGIATE PROFRSSOR OF LATIN IN THE JOHNS HOPKINS UNIVERSITY

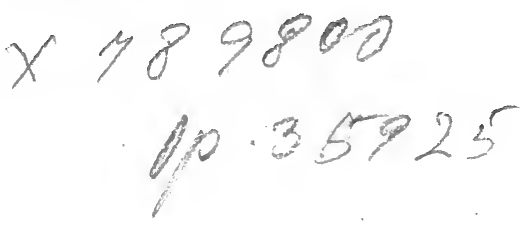

\section{BALTIMORE}

THE JOHNS HOPKINS PRESS 
773

132र2

1911

uplace nw.225284 fing to Has 


$$
1
$$




\section{I}

COPYRIGHT, IgII

BY

THE JOHNS HOPKINS PRESS 
$\underbrace{3}$

TO

KIRBY FLOWER SMITH

运

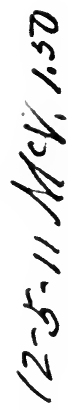





\section{PREFACE}

TH1s edition has been prepared in the hope that some scholars might be glad to study a set of forgotten poems which had a very considerable influence upon the English literature of the sixteenth century.

The Text is based upon that of the first printed edition, of Mantua, 1498. The more important later variants are mentioned in the notes. The spelling is modified to suit the convenience of the modern reader. The punctuation is my own.

The Introduction has grow: to a portentous length, pastly because it seemed desirable to set down my authority for almost every statement. And inasmuch as many of my authorities are not easily accessible-at least, to American scholars-it often seemed necessary to quote their actual words. Hence the "leaden sediment" of footnotes. I am rather ashamed of this unlovely feature, but I feel that any one who has tried to find any modern account of Mantuan which is at once definite and accurate will be inclined to excuse it. Perhaps I should add that a part of my material has already heen printed, in the Transactions of the American Philological Association, vol. XL.

I have devoted a good deal of space to the story of Mantuan's popularity in England, and tried to show some: thing of the precise range and character of his influence there. It would be interesting to know whether his Eclogues exercised any such influence in Italy, or France, or Germany; but that subject must be left to others.

My Notes are mainly concerned with the question of Mantuan's sources, and only occasionally serve to explain his meaning. I had thought of putting them below the text, but they are hardly of sufficient importance to break 


\section{PA8463 \\ $B 7 E_{26}$}

up the page, and, besides, the reader may be glad to have the Eclogues printed, for once, so that he can see more than a few lines at a time. Ever since Ascensius published his long-lived commentary they have regularly been printed with alternate stretches of text and notes on the same page.

I hope that most of my obligations to earlier writers are duly acknowledged in the footnotes. My Introduction is much better than it might have been because of the generosity of Mr. HENRY Walters, of Baltimore, who allowed me the free use of his magnificent private library of Italian incunabula. And it is further enriched by material which I was able to collect last summer during a vacation tour of the great public libraries of Italy. It gives me pleasure to recall the uniform courtesy and kindness which I received from various library officials in Turin, Milan, Mantua, Ferrara, Bologna, and a dozen other cities. And I am glad to say here that my book owes a great deal to Cav. Alessandro Luzio, Director of the R. Archivio di Stato at Mantua. From one of his published papers I had learned most of what I have written about our poet's family, and by his special knowledge and ready helpfulness he made my own work at Mantua both profitable and pleasant.

BALTIMORE,

W. P. M.

May, 1911. 


\section{CONTENTS}

\section{INTRODUCTION}

"Good old Mantuan" ............................. Ix

His Life ...................................... n

His Family and Friends $\ldots \ldots \ldots \ldots \ldots \ldots \ldots \ldots \ldots \ldots, 18$

His Works $\ldots \ldots \ldots \ldots \ldots \ldots \ldots \ldots \ldots \ldots \ldots \ldots \ldots \ldots \ldots, 26$

His Popularity ........................... 30

Composition and Publication of the Eclogues .......... 35

Their Use as a School-book ...................... 36

Quotations and Allusions ....................... 40

Imitations $\ldots \ldots \ldots \ldots \ldots \ldots \ldots \ldots \ldots \ldots \ldots \ldots \ldots \ldots \ldots, 48$

Mantuan's Sources $\ldots \ldots \ldots \ldots \ldots \ldots \ldots \ldots \ldots \ldots \ldots \ldots \ldots, 57$

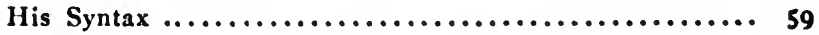

His Metre .............................. 59

His Vocabulary .......................... 59

Dedicatory Epistle $\ldots \ldots \ldots \ldots \ldots \ldots \ldots \ldots \ldots \ldots \ldots \ldots \ldots \ldots, \mathbf{6}_{2}$

Text $\ldots \ldots \ldots \ldots \ldots \ldots \ldots \ldots \ldots \ldots \ldots \ldots \ldots \ldots \ldots \ldots \ldots, 6_{3}$

Notes $\ldots \ldots \ldots \ldots \ldots \ldots \ldots \ldots \ldots \ldots \ldots \ldots \ldots \ldots \ldots \ldots \ldots \ldots, 121$

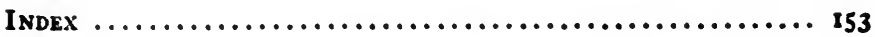




\title{
INTRODUCTION
}

\author{
" COOD OLd Mantuan"
}

IN Love's Labour's Lost, IV, 2, 95, the schoolmaster Holofernes quotes the Latin words "Fauste, precor, gelida quando pecus omne sub umbra Ruminet,-and so forth," and then exclaims: "Ah, good old Mantuan! I may speak of thee as the traveller doth of Venice;

Venetia, Venetia,

Chi non ti vede non ti pretia.

Old Mantuan, old Mantuan! who understandeth thee not, loves thee not." Herc the modern reader is apt to think of the Eclogues of Virgil; but the reference is to another and much later poet who was likewise a native of Mantua, and likewise the author of ten Latin eclogues. This was Baptista Spagnolo, or, as he was commonly called, Baptista Mantuanus. ${ }^{2}$

\section{HIS LIFE}

This later Mantuan was born April 17, 1448.2 He way a pupil of Gregorio 'Tifernate and of Georgius Merula;"

2 In one of the letters of Isubella d' Este (Aug. 23, 1504) he is called "R.do frate Bap." Spagnolo"; S. von Arx, Romanische Forschungen, xxv1, 813. In a proclamation of the Marquis of Mantua (June 25, 1514) he is "R.da mag." Bap." Spagnolo"; LuzioRenier, Giornale storico della letteratura italiana, Xxxıv, 57. In the closing novel of Sabadino's Porrettane he is "maestro Baptista Spagnolo Mantoano."

2 Tiraboschi gives this date, "from documents of the Carmelite monastery at Mantua." In a little poem Vitae suae Epitome our author states that he was born in the reign of Pope Nicholas V"istius accepi lucis primordia, quintus | in solio Petri cum Nicolaus erat"-which means not earlier than March 6, 1447. In the dedicatory epistle prefixed to his Eclogues, Sept. 1, 1498, he calls himself "quinquagenarius".

3e seems to have studied under both of these teachers at Mantua: F. Gabotto, Ancora un letterato del Quattrocento, 1890, pp. 22-23. 
and he afterwards studied philosophy at Padua. About 1466 he entered the Carmelite monastery at Mantua. In 1472 he was appointed "lector" in the monastery of San Martino at Bologna."

During his term of service there his monastery was visited by the plague ${ }^{7}$ but he was sheltered and nursed by a wealthy friend in the city, Lodovico Foscarari:

Nuper in cenobium nostrum dirae pestilentiae immisso veneno toti urbi coeperamus esse timori; pellebamur non a colloquio tantum verum etiam a conspectu hominum ... interclusi eramus nec ulla videbatur evadendi via : omnia mortem intentabant ... tu cum Refrigerio nôstro ... spem vitae confirmasti, xenia misisti, in amplas ac magnificas aedes tuas hospitio me suscepisti, lautissime et elegantissime pavisti. ${ }^{8}$

And he afterwards found a refuge at the villa of Gio. Baptista Refrigerio, "on the upper waters of the torrent Claterna, on the way to Rome":

Gregorio seems to have been in Mantua from April, 1460, till December, 1461; Merula, from 1460 till 1463. Gregorio was the "Umber" of the Eclogues (IV, 8I, $95 \mathrm{ff}$., $246 \mathrm{ff}$.; V, IOI; VII, IO; IX, 200), as Mantuan himself explained to Thomas Wolf, Jr., in the year 1500. See note on Ecl. IV, 81. Cf. also the Apologia written by the poet's brother Tolomeo: "Gregorium Tiphernatem quem poeta noster habuit praeceptorem" (Lyons ed., 1516, fol. Ee, v), and a letter written by Mantuan to Pico della Mirandola, the Younger, Jan. 3, 1495: "mors Georgii Merulae primum condiscipuli postea praeceptoris mei (nam sub Gregorio Tiphernate commilitavinus) tristitia me affecit" (Ioannis Pici Mirandulae Concordiae Comitis opera, Bologna ed., 1496, fol. I6Ib).

- See the dedication of his Eclogues: "ante religionem, dum in gymnasio Paduano philosophari inciperem."

5 "Religio placuit iuveni," etc., Vitae suae Epitome. The date usually given, 1464, seems to be too early. The first eight Eclogues were written "ante religionem"; the fourth laments the death of Gregorio Tifernate; and Gregorio seems to have lived at least till 1464 .

- Florido Ambrogio, De rebus gestis ac scriptis operibus Baptistae Mantuani, Turin, $1784, \mathrm{p}$. 28. In the title of the De vita beata (printed in 1474) he is called "professor".

7 Probably c. 1478; see Muratori, Annali d' Italia, Anno 1478. L. Frati gives the exact date as 1479, Giorn. stor. d. lett. ital., XII, 327.

Dedication of the first Parthenice, published Feb. II, I48I. 


\begin{abstract}
ipse quoque in silvis et vallibus Appennini exilem ducens tecto sub paupere vitam delitui qua templa petit Romana viator et qua Flaminios fugiens Claterna per agros ducit ab angustis undosum vallibus amnem arce sub Ociami, nostris ubi dicta Camenis tecta Refrigerius sublimi in colle tenebat.
\end{abstract}

In 1479-80 he held the office of Prior at Mantua.10 In 1483 he was elected Vicar-general of the Carmelite Congregation of Mantua. ${ }^{11}$ And to this office he was re-elected five times-each time for a period of two years, with an interval of four years-in 1489, 1495, 1501, 1507, 1513.12

The first term of his office and the first interval were spent mainly at Rome, on the business of his Congregation. ${ }^{18}$ The city was disturbed by the Orsini and Colonna

- De suorum temporum ca!amilatibus, Lib. I. The Claterna receives a grateful mention again in the poem Alfonsus, Bologna ed., 1502, fol. 260.

10 Florido Ambrogio, op. cit., 43, who adds that he was appointed tutor of the Marquis Federico's children. On Jan. 23, 1479, he wrote to his friend Refrigerio from Reggio, explaining that he had fled from Mantua because of the plague; on Jan. 29, 1480, and Feb. 16, 1480, he wrote to him from Mantua. In 1476 (Apr. 28 and July 21) and in 1478 (Aug. 12) he had written to the same correspondent from Bologna. In 1481 and 1482 he seems to have been again in Bologna. The first Parthenice was published at Bologna, Feb. II, 1481 , and in the same year Refrigerio could call himself Mantuan's pupil : "ipse, qui eius disciplinas quotidie haurio" (L. Frati, Giorn. stor. d. lett. ital., XIr, 327-8). On Oct. 8, 1482, and Nov. 2, 1482, he wrote to Caesar Napeus, of Brisighella, from Bologna. [There are manuscript copies of the letters mentioned in this note in the Library of the University of Bologna.]

11 "Congregationis Mantuanae Observantium Carmelitarum Vicarius," as he calls himself in his prose account of the Santa Casa at Loreto (Sept. 22, 1489). In 1413, three Carmelite convents, Le Selve (near Florence), Gerona, and Mantua, agreed to correct certain abuses which had crept into the order; and this combination developed into the Congregation of Mantua, or Mantuan Reform. In 1442, it achieved quasi-autonomy under a vicar-general. By Mantuan's time, it had brought under its authority several other houses in northern Italy, Novellara, Modena, Ferrara, etc.

12 Florido Ambrogio, op. cit., 63, 69, 77, 78, 81, 84.

18 The Epigrammata ad Falconem were written during this period, and so were some of the Silvae. In the Epistola contra Calumniatores he says, "dum Romae sub Sixto quarto agerem" (Lyons ed., 1516, fol. Aa, vi); and Florido Ambrogio records (op. cit., 


\title{
factions, and he found great difficulty in getting a hearing for his case:
}

\author{
Turbida nunc Ursos clamat, nunc Roma Colunnam; \\ esse quid attonita pacis in urbe potest? \\ et nisi Falconis scirem me numine tutum \\ iam mea populifer cerneret ora Padus. \\ propterea divi repetes cum limina Petri, \\ ne fluat in longos fac mea causa dies.14
}

Still he received much assistance from a young friend, Filippo Baveria:

tu mihi tractanti Romana negotia semper assiduas operas auxiliumque dabas.

65) that it was through his efforts that in 1483 Sixtus IV confirmed the privileges granted to the Congregation of Mantua by Eugenius IV. The poem Pro pacata Italia post bellum Ferrarierse (Silvae, viI, 6) seems to celebrate the peace of August, 1484: and it is addressed to the Cardinal of Naples. The poem In Romam bellis tumultuantem (Silvae, II, 7), with its allusion to the strife of the Orsini and Colonna factions, probably belongs to the same year. But the Consolatio addressed to his friend Sabadino is dated at the end "Bononiae die secunda Februarii, 1485." And the Panegyricum on Roberto da San Severino (1485) was not written at Rome: " $i$. decus Italiae, tantoque accinge labori" (Bologna ed., 1502, fol. liii). Silvae, 1,3 and v, 4 (both addressed to Innocent VIII) refer to the Spanish embassy which arranged peace between the Pope and the King of Naples in August, 1486-and in one of them our poet writes as an eye-witness. The Somnium Romanum (1487) was written at Rome: " nam tunc ego templa tenebam / trans Tiberim," Tolentinum, Bk. III (Lyons ed., 1516, fol. E, ii). The Contra poetas impudice loquentes was finished at Rome, Oct. 20, 1487 , as is stated at the end of the poem in the Bologna editions of 1489 and 1502. The second Parthenice was written at Rome (as its dedication states), apparently in the summer of 1488 . On Aug. 25, 1488, he wrote to his friend Refrigerio from Rome (Autograph letter in the Library of the University of Bologna). And a letter to Pico della Mirandola, Oct. I, 1490, seems to refer to the same year: " nam dum ego Romae gravibus admodum rei publicae meae negotiis insudarem, eo tempore quo tu quoque, ut meministi, tantis illis aemulationum fluctibus laborabas," etc. (prefixed to the Bologna edition of the collected poems, 1502). There is still another reference to his life in Rome in the De Patientia, II. 22: "verum est id quod ad Falconem, cum Romae essem, scripsi hoc disticho," etc.

14 This quotation and the next three which follow come from the Epigrammata ad Falconem. 
Through the good offices of the papal treasurer, Falcone de' Sinibaldi, ${ }^{16}$ he gained admission to the court:

te duce Pontificis summi mihi limen apertum, et sancti patuit regia magna Patris.

And he must have received, or hoped for, some help from another "great star of the Roman Senate," Oliviero Carafa, Cardinal of Naples: ${ }^{16}$

\section{hi sunt Romulei duo sidera magna senatus unde bonis lumen praesidiumque datur.}

In the poem prefixed to the Epigrammata ad Falconem he is still begging that the Carmelites of Mantua may have a house of their own at Rome:

\section{cur igitur, quoties Romana revisere tecta cogimur, in propria non licet esse domo?}

But in 1489 his long efforts were rewarded by the gift to his Congregation of the church and monastery of S. Crisogono. ${ }^{17}$

In 1489 he went from Mantua to Loreto, at the head of a company of Carmelite friars, who were to be put in charge of the Santa Casa. ${ }^{18}$ In 1490-at least from March to October-his correspondence shows that he was in Bologna..

18 "Cuius beneficio ex omnibus periculis est liberatus." This is the "Falco" of the ninth Eclogue, a poem which doubtless reflects some of Mantuan's own experiences at court.

${ }^{10}$ To whom the De suorum temporum Calamitatibus was dedicated.

17 Florido Ambrogio, op. cit., 68. As an evidence of Mantuan's personal success at Rome, Ambrogio mentions (p. 35) an oration which he delivered in the presence of Innocent VIII, in 1488 . In one of his Silvae $(\mathrm{I}, 4)$ he celebrates the birthday feast of the Pope's nephew, Lorenzo Cibo, Archbishop of Beneventum. And in the $V$ ita Lodovici Morbioli he could thank Pope Innocent for varions personal favors, including a gift of money-" aureaque aegroto munera missa mihi."

18 Florido Ambrogio, op. cit., 69-70; U. Chevalier, Notre-Dame de Lorette, Paris, 1906, p. 322.

10 A letter addressed to him, March 20, 1490, by Pico della Mirandola includes a greeting to Filippo Beroaldo, "saluta Beroaldum." Another letter from the same correspondent, Sept. 19, 1490, asks for a 
But he probably spent most of his remaining life at Mantua. ${ }^{20}$. On May 22, 1513, he was elected General of the entire. Carmelite Order; and he seems to have held this office till his death. ${ }^{21}$ During his brief term of office he consolidated the congregation of Albi, a French imitation

catalogue of the monastery library at Bologna: "indicem bibliothecae vestrae Bononiensis, si id tuo commodo fieri potest" (Ioannis Pici Mirandulae Concordiae comitis opera, Bologna, 1496, foll. 145, 150). And Mantuan's reply to this second letter is dated at Bologna, Oct. I, 1490 (quoted in the Bologna edition of his collected poems, 1502).

20 In 1493 (Oct. 22) he delivered a funeral oration at Mantua, on Leonora d' Aragona, the mother of Isabella d' Este (printed copy in the Biblioteca Comunale at Bologna). In 1494 (Oct. 29 and Nov, 27) and in 1495 (Jan. 3) he writes to the younger Pico della Mirandola from Mantua (I. P. Mirandulae opera, Bologna, 1496, foll. 164, 161, 16Ib). [J. H. Lupton, Life of Dean Colet, 1887, p. 67, says that Colet may have met with Mantuan "in Paris, where (according to Trittenheim) he was staying in 1494."] In November, 1496 he seems to have been at least temporarily absent from Mantua, for his oration In funere Ferrandi Regis was delivered by his friend Pietro da Novellara (Luzio-Renier, op. cit., 69). In 1497 he was in Florence, as the dedication of his Eclogues states: "anno praeterito, cum Florentia rediens Bononiam pervenissem," etc. In 1500 he was at Mantua: "Ego dum Bononiae ingenuis disciplinis vacarem in ipso iubileo anno profectus sum Mantuam, ut Baptistam quem ex libris noveram coram quoque viderem," etc. (Letter of Thomas Wolf, Jr., to Jakob Wimpfeling, Feb. 24, 1503). In August, 1504, a letter of Isabella d' Este promises to send to Giovanni Sabadino "sei sacchi di frumento"; and the gift is to go to Bologna in charge of the "R. do frate Bap." Spagnolo" (S. von Arx, Roman. Forsch., xxvi, 813). On July 1, 1506, he wrote to his brother Tolomeo: "In questo tempo di questo nostro exilio ho fatto trascrivere tutte le nostre cose nove" (F. Gabotto, Un poeta beatificato, 1892, p. 17).

21 Ventimiglia, Hist. Chron. General. Carm., Naples, 1773, p. 17I. Many ancient and modern accounts say that Mantuan soon resigned his high office-because his reforms were opposed, or in order to devote himself entirely to literature. Possibly the tradition is based upon a remark by Seb. Murrho, in the preface to his commentary on the first Parthenice: "audivimus ex Conrado Leontorio, quo a secretis familiariter utimur, magistratu se quem in eo ordine summum gessit abdicavisse, ut liberius humanis divinisque litteris vacare posset." This preface is not dated, but it was printed in 1513 (at the beginning of Ascensius' Paris edition), and it may have been taken to refer to that year. But Murrho died in 1495 ; and his report must refer to Mantuan's aoffice of Vicar-general, not to his office of General at all. 
of the Mantuan Reform. ${ }^{22}$ In 1515 he was appointed Apostolic Legate to arrange peace between Francis $I$ and the Duke of Milan ; ${ }^{28}$ but he was prevented by age and infirmity from undertaking this mission. He died at Mantua, March $20,1516 .{ }^{24}$ He was beatified December 17, 1885. ${ }^{23}$

In form and feature Baptista was not very handsome or imposing. One of his admirers who visited him in the year 1500 can only say, with Odysseus, that " the gods do not give!. every gracious gift to all, neither shapeliness nor wisdom nor skilled speech"26_" scias id rectissime posse de Baptista dici quod Homerus et ceteri vates de Ulysse rettulerunt, qui corpore parvus et forma indecorus sed ingenio maximus et animo speciosissimus fuisse perhibetur." 27 So Luca Gaurico calls him "parvus et modicae staturae," in his Tractatus Astrologicus. ${ }^{28}$ And Bandello says that he was very ugly: " era brutto come il culo, e pareva nato dai Baronzi." 29

22 Catholic Encyclopedia, II (1907), 276.

23 Florido Ambrogio, op. cit., 93; A. Luzio, Archivio storico italiano, XL (1907), pt. 3, p. 1 .

${ }^{24}$ His epitaph, in the Carmelite church at Mantua, is quoted by Saverio Bettinelli, Delle Lettere e delle Arti Mantovane, Mantua, 1774, p. 99: “R. P. Magister Jo. Bapt. Mantuanus Carmelita Theologus Philosofus Poeta Orator clarissimus latinae graecae \& hebraicae linguae peritissimus." His tomb is now in the Cathedral at Mantua.

25 The Decretum is quoted by Fanucchi, Della Vita del Beato Battista Spagnoli, Lucca, 1887, pp. $217-18$.

${ }^{26}$ Homer, Od., vili, 167. Cf. Ov. A. A., 11, 123, "non formosus erat, sed erat facundus Ulixes."

27 Letter from Thomas Wolf, Jr., to Jakob Wimpfeling, written at Strassburg, February 24, 1503.

28 Quoted by F. Gabotto, Un poeta beatificato, 1892, p. 8.

${ }^{29}$ Novelle, III, 52, fin. (quoted by Luzio-Renier, op. cit., 66). The Baronzi were a Florentine family, proverbial for their homely features. Bandello's lively description is hardly borne out by the surviving portraits of the poet. There are at least three busts of him at Mantua; and these suggest only a rather benevolent countenance with a very prominent nose. One is a contemporary portrait in terra-cotta, now in the Museo Patrio; another is a large bust, in hronzed wood, now in the Palazzo degli Studi (it was transferred thither "ex aede Carmelit." in 1783); while a third may be seen above the poet's tomb in the Cathedral. There is another very interesting bust, in bronze, in the Royal Museum at Berlin; this is beautifully reproduced for an article by W. Bode; Jahrbuch der 


\section{HIS FAMILY AND FRIENDS}

As a member of a monastic order-Frater Baptista Mantuanus-our author never calls himself by his family name. He was the son of Pietro Spagnolo, a Spanish nobleman from Granada, who had himself lost his family name of Moduer (or Modover) and received the name Spagnolo, from the name of his own country. ${ }^{30}$ His father, and his grandfather, "Antonius Cordubensis," ${ }^{31}$ took part in the naval battle off Gaeta in 1435-when Alfonso V of Aragon was defeated by the Genoese. Being taken prisoner along with their king, they spent some time at Milan; and they remained in Italy after Alfonso was released:

Hesperios inter proceres quos invida laudi in praedam fortuna dedit tum prima ferebat Alfonso sub rege merens Antonius arma cui genus et patrium dederat sua Corduba nomen. . . ipse pium casus dominum comitatus in omnes venit ad Insubres ubi, postquam vincula passo affuit Alfonso melior fortuna, relictus, seu fuerit casus seu caeli inmobile fatum, egregium decus et nomen sibi fecit in armis. ${ }^{33}$

Königlich Preussischen Kunstsammlungen, 1889, Heft iv. These busts are doubtless more reliable than the rude woodcut which adorns the Lyons edition of Mantuan's later works, 1516, the frontispiece of the Cologne edition of the E.clogues, 1688, or the highly idealized portrait which appears in the biography by Florido Ambrogio, Turin, 1784 .

30 "Petrus Spagnolus," as he is called in the title of the De vita beata. In his epitaph (in the Carmelite church at Mantua) he was called "Petrus Sp. Modover" (quoted in d'Arco's MS. history, in the R. Archivio di Stato at Mantua).

s1 Cf. Baptista's oration In funcre firrandi regis (printed at Brescia in 1496): "sub hoc Alfonso avus meus Antonius Cordubensis in Italiam venisse et meruisse se narrabat, cum ego ndhue puer senem admirarer more veteranorum militum sui temporis bella recitantem." In the Trophaeum pro Gallis cxpulsis, Bk. v (Bologna ed., 1502, fol. 374b), he says of his brother Tolomeo:

\section{proavos fecunda virorum}

magnanimorum altrix et mater Corduba vatum huic dederat, proavos armis et sanguine claros.

So Paulus Jovius says "exं Hispaniola gente honesta" (Elogia virorum literis illustrium. Basel ed., 1577, p. 117).

82 Alfonsus, Bk. v (Bologna ed., 1502, fol. 303). There is a similar 
Pietro went to Mantua, and there rose to high favor with the reigning house:
Petrus enim senis Antoni generosa propago
Mintiadas adiit populos, ubi Gonzagarum regia, et insignem claro sub principe nactus eximia virtute locum primordia genti condit; et annoso cedet iam frigidus aevo.

In 1457 he appears as steward (sescalco) of the Marquis Lodovico, who in 1460 conferred upon him and his sons the citizenship of Mantua. ${ }^{33}$ He enjoyed the favor of the next two marquises also, Federico and Francesco, and lived to round out fifty years of faithful service to their house. He died early in 1494.

In his Vitae suae Epitome Mantuan states that his father encouraged his youthful studies:

a teneris colui Musas, mihi semper ad artes ingenuas calcar cura paterna fuit.

There is a passage in the seventh Eclogue, $59 \mathrm{ff}$., which has been regarded as a reference to the author's own life:
durus et immitis pater atque superba noverca
Pollucem graviore iugo pressere iuventae
tempore, cum dulces animos nova suggerit aetas.
et cum iam invalidae longo sub pondere vires
deficerent nullaque odium mansuesceret arte, constituit temptare fugam, etc.

"Videtur autem haec vera vitae ipsius poetae descriptio,"

account in the Epithalamium addressed to the poet's brother Tolomeo (Antwerp ed., vol. 111, fol. 302). This gives a different explanation of Antonio's remaining in Italy: "ad Ducis ascitus magno aere Antonius arma."

s3 S. Davari, Della famiglia Spagnola, quale risulta dai documents dell' Archivio Storico Gonzaga, Mantua, 1873 , p. 4. Cf., also, the Dialogus contra Detractores, Lyons ed., 1516, fol. e, i: "Petrum videlicet patrum tuum, virum ornatissimum ac splendidissimum, sub huius nostri principis patre atque avo domi forisque in praeclaris negotiis summa cum laude semper versatum." In a letter to the Marquis Francesco, Nov, 10, 1494, Baptista could say, of his father's services to the Marquis' house: "el quale cinquanta anni continui servi," etc. (Autograph letter preserved in the R. Archivio di Stato at Mantua). 
as Ascensius immediately explained it. And Niceron saw in the "superba noverca" a hint of the poet's illegitimate birth. * But this interpretation hardly agrees with the fact that his early treatise $D e$ vita beata is addressed to his father in terms of affection: "ego enim qui te mihi carior sit inter mortales habeo neminem."

Baptista had many brothers and sisters. ${ }^{85}$ The eldest, Tolomeo, ${ }^{80}$ became the confidential secretary of the Marquis Francesco, and rose to such favor that he was even allowed to take the name of Gonzaga. ${ }^{87}$ But he grossly abused this confidence-by forgery and fraud and trafficking in justice-and after the death of the Marquis (1519) he was forced to flee from the city. ${ }^{38}$. Another brother was

34 Mémoires (Paris ed., 1734), xxvir, 107, "il se plaint, sous le nom de Pollux, des rigueurs et de la fierté de sa belle-mère, qui ne peut-être autre que cette Constance."

35 "ampla | nostra domus pollens numero fratrum atque sororum," Epithalamium (Antwerp ed., 1576, 111, fol. 302).

30 Tolomeo seems to have been of illegitimate birth; and Baptista himself may have been "ex damnato coitu natus," as Paulus Jovius puts it: S. Davari, op. cit., 4-9. In the Epithalamium already quoted, Baptista calls Tolomeo-and apparently himself-the son of Costanza de' Madi (or de' Maggi), of Brescia :

haec est Maia domus pollens propagine tanta,

tot claris ornata viris; Constantia mater

hinc, germane, tibi nuribus praelata pudicis.

37 By a decree of the Marquis, Jan. 6, 1507: S. Davari, op. cit., 10. In the dedication of the Dialogus contra Detractores, and in a letter of Mario Equicola (Nov. 10, 1508), he is called "Ptolemeus Gonzaga." At the close of the Dialogus, Baptista says of him: "ob singularem fidem atque industriam in Gonzngarum familiam privilegio ascitus" (Lyons ed., 1516, fol. e, i) ; and Equicola has, "huic cum Ptolemeus a secretis solus prinus sit voluntatum et consiliorum adiutor et particeps." In the Trophaeum pro Gallis expulsis, Bk. v (a passage referring to the year 1496), he is introduced as comforting the Marchioness Isabella:

tristibus his curis aderat facundus et acri

ingenio praestans iuvenis Ptolemeus

(Bologna ed., 1502, fol. 374).

38 Baptista addressed to him his sixth Parthenice (on St. Apollonia), a poem on the death of their brother Federico Antonio (1506), a Dialogus contra Detractores, and an Epistola contra Calumniatores. Tolomeo published a learned Apologia contra detrahentes operibus $B$. $M$. (c. 1509), and after our poet's death we find him arranging for a worthy monument for him (Luzio-Renier, op. cit., 63). 
the Canon Alessapdro, who is mentioned in a document of December 1497 as judge in a law-suit between the youthful Raffaello Sanzio and his stepmother. There he is called "decretorum doctor " and "vicarịo del vescovo urbinate." 3 " About 1507 he is made one of the speakers in the Dialogus contra Detractores, and called "praeclarus iurisconsultus et nostrae cathedralis erclesiae canonicus." "o But Alessandro becaine implicated in his brother's frauds, and after their exposure he joined the erring Tolomeo in Rome. ${ }^{41}$ There is a pleasant glimpse of a third brother, Roberto Lucano, in a letter written by Baptista to Tolomeo, Sept. 8, 1503. Here it is reported that Roberto has returned to Mantua after spending some time in the Levant, in the service of the Venetian State. He has brought back a Venetian accent, and a knowledge of spoken Greek, and all the air of a man of the world. And now he wishes to return to Venice, and hopes to go with the Venetian ambassador to the King of Spain. ${ }^{2}$ Still another of this talented family-" claris de tot mihi fratribus unum," as Baptista might well call him - was Federico Antonio, who died of the plague in 1506. This was the accomplished orator who had stood before kings and princes, who knew all law and all histories, who was loved of all the Muses, who spent his days and nights in study, sitting among his books like a consul among the senators and asking each in turn what advice or information it could give :

lucra nihil curans, nihil emolumenta, sedebat inter mille libros velut in coetu atque corona mille senatorum consul, quid sentiat unus quisque super rerum causis et origine tota luce rogans et nocte domi, quam plurima chartis lucubrata diu mandans studioque reponens multa gravi, quae forte sequens mirabitur aetas. ${ }^{48}$

80 Luzio-Renier, op. cit., 62.

10 In a decree of April 28, 1515, he is called "canonico mantovano e consigliere del Marchese :" S. Davari, op. cit., 14.

-1 Baldessar Castiglione had previously gone to Rome, to ask permission to proceed against him: Luzio-Renier, op. cit., 62.

12 Luzio-Renier, op. cit., 62. In a decree of Oct. 17, 1511, he is called "segretario marchionale": S. Davari, op. cit., 14

18 De morte Federici Spagnoli fratris sui (Ascensius' ed., Paris, 1513, vol. II, fol. 161). 
Other members of the family were Berardo, whom Baptista could recommend to the Marquis (Nov. 10, 1494) as "del corpo prosperoso et assai litterato et di bono ingegno ;" 14 Cesare, who is mentioned in a dncument of Aug. 14, 1512, as "spectabilis et eximius artium et medicine doctor ;" and a Dominican friar (perhaps named Paolo) whom Baldessar Castiglione found in Rome in 1519.45 There were two sisters, Anna and Margherita. And still another brother was Egidio, ${ }^{40}$ who died in battle in 1509-when the Marquis Francesco was surprised and captured in a night attack, near Legnago:

nos quoque tempestas ista, o Ptolemaee, redegit in luctum, in lacrimas, longa in suspiria, quando Aegidius frater nobis cum Principe raptus ante diem, missus Princeps in vincula, frater in tumulum, datus in praedam furialibus armis. ${ }^{47}$

From Mantuan's own writings we can collect a long list of his friends and patrons in various cities. It must have meant much to him in his later years that he enjoyed the favor and the patronage of the Gonzagas-especially of the Marquis Francesco, the Marchiuness Isabella (who is best known as Isabella d'Este), and the Cardinal Sigismondo. ${ }^{48}$

14 Autograph letter in the R. Archivio di Stato at Mantua.

45 " un fratello del Tolomeo Spagnolo che è frate in S. Domenico e si lamenta delle calunie che si spargono sul conte di Tolomeo e di Alessandro" (S. Davari, op. cit., 15).

40 "Cancelliere della Segreteria di Corte" from 1504 to 1506: S. Davari, op. cit., I5.

47 De fortuna Fr. Gonzagae (Antwerp ed., 1576, III, fol. 188). The same events are mentioned in the De bello Veneto anni 1509 (Lyons ed., 1516, fol. F, iii).

48 For the Marquis he wrote the five books Trophaeum pro Gallis expulsis (c. 1498) and a Carmen de fortuna F. G. (1509). To the Marchioness he dedicated the third, fourth, fifth, and seventh Parthenicae (on St. Margarita, St. Agatha, St. Lucia, and St. Caecilia), an elegy on the death of Pietro da Novellara (1504), a " silvula" $D=$ Cupidine marmoreo dormicnte, and a poem on the death of Niccolii da Correggio (1508). To Sigismondo (then "protonotarius") he dedicated the Silvae; to the same patron (when Bishop of Mantua) a Tractatus de loco conceptionis Christi, and (when Cardinal) an Apologia contra eos qui detrahunt ordini Carmelitarum. The Marquis is further complimented by being included in an address to the various Christian potentates which urges them to take up arms against 
And he had other good friends at Mantua, in Paride Ceresara, ${ }^{\circ 9}$ Baptista Fiera, ${ }^{80}$ Andrea Mantegna ${ }^{61}$ and Mario. Equicola." ${ }^{52}$ But he had already made many friends in Bologna, and Florence, and Rome. At Bologna, he owed much to Gio. Baptista Refrigerio and Lodovico Foscarari (who have been mentioned above, p. 12), ${ }^{53}$ and he was on intimate terms with the novelist Sabadino, ${ }^{5 t}$ with Count Andrea Bentivoglio, ${ }^{55}$ Antonio Fantuzzi ${ }^{\text {58. }}$ and Filippo Beroaldo. ${ }^{37}$ Of friends made at Rome, we have already mentioned Filippo Baveria, Falcone de' Sinibaldi and

the Turk. And a letter from Gioviano Pontano, June 1, 1499, suggests that Mantuan had tried to enlist his aid in celebrating the exploits of his patron: "de principe vero tuo illustrando, bonam tibi promittere voluntatem possum; verum quid promittat, cui nihil omnino est quod det in penu? non deero tamen virtutibus fortissimi ac magnanimi ducis" (printed in the Bologna edition of Mantuan's collected poems, 1502). The new Catholic Encyclopedia (II, 276) states that it was "through the exertions of his former disciples," the Marquis and the Cardinal, that Mantuan was elected General of his order.

49 To whom the revised Eclogues were dedicated, Sept. I, 1498. For some account of him, see p. 121.

50 Who is praised as a physician and as a poet. Trophaeum pro Gallis expulsis, Bk. v (Bologna ed., 1502, fol. 375). See, also, Luzio-Renier, op. cit., 54-57. A sumptuous edition of his poems was printed at Venice in 1537 .

51 The well known painter. His skill is celebrated in Silvae, 11, 6.

52 Secretary to Isabella d' Este. In a letter of Nov. 10, 1508, he expresses his readiness to reply to Baptista's detractors.

53 The two friends to whom he dedicated the first Parthenice. For Refrigerio, see L. Frati, Giorn. stor. d. lett. ital., XII, 327-8, and S. von Arx, Roman. Forsch., Xxvi, 770. In 1481 he calls himself Mantuan's pupil.

64 To whom he wrote a Consolatio on the death of a son (1485), Silvae, 1,7 . Mantuan is introduced in very complimentary fashion in the closing novel of the Porrettane. See, further, S. von Arx, op. cit., $77 \mathrm{I}$.

53 To whom he dedicated the Somnium Romanum (c. 1487). See, further, S. von Arx, op. cit., 771 .

56 For whom he composed the De Patientia.

$57 \mathrm{Cf}$. Beroaldo's letter to the editor of the collected poems, Bologna, 1502: "Gaudeo ipse mecum et gestio, quod talem virum non solum familiariter noverim sed etiam habuerim confessorem." See, also, Mantuan's poem De reditu Philippi Beroaldi iuvenis literatissimi ex Gallia (Silvae, viI, 4). 
Oliviero Carafa, Cardinal of Naples ; and to these we should add Pomponius Laetus, ${ }^{58}$ Gio. Gioviano Pontano, ${ }^{30}$ and perhaps also Alessandro Cortese ${ }^{\circ 0}$ and Petrus Marsus. ${ }^{\circ 1}$ At Florence, he had very distinguished friends in Pico della Mirandola (both the uncle and the nephew) and Angelo Poliziano; and his correspondence shows that his friendship with these men (as with Beroaldo) was not merely a formal matter, but something very real and intimate.

In a letter to Mantuan, Jan. 13, 1490, Pico answers a request for the loan of a copy of Philostratus: "en tibi Apollonium, quem si tuae virtuti, tuis in me officis non deberem, deberem certe vel his litteris quibus eum efflagitas. tantus in illis amor, tanta humanitas." ${ }^{82}$ In a second letter, Mar. 20, 1490, he has to speak of a passage of Philostratus, and of a passage in the Book of Genesis:

de Apollonio Thyaneo nihil sentio magis quam quod tu sentis, super qua re scribam ad te plura, cum erit otium, et quae tibi erunt fortasse non ingrata. de diversitate translationis nostrae a littera Hebraica in tertio capite libri Geneseos, ubi de Eva agitur et serpente, sic equidem censeo, etc.

58 To whom the Epigrammata ad Falconem profess to have been submitted for criticism. In the Epistola contra Calumniatores he is called "mihi familiarissimus" (Lyons ed., 1516, fol. Aa, vi).

59 Pontano is mentioned in complimentary fashion in the second book of the Trophaeum, where Fame carries the news of Fornovo to King Ferdinand, "Pontanique ora poetae 1 accipit." His letter to Mantuan already cited begins: "Et initae Romae memor sum amicitiae, et ingenii tui excellens vis momentis paene singulis id efficit ut doctrinae vel summa etiam cum aumiratione meminerim tuae. an eius ego obliviscar? quem Latinae Musae non memorabilem modo verum maxime etiam admirabilem et nostris faciunt et facturae sunt saeculis." He adds that he is sending some samples of his historical work, and will send some of his other compositions later. And Mantuan acknowledges the receipt of some of these poems in Silvac, vr, 1. Pontano is mentioned also in Tolomeo's Apologia: "erat enim ille vir poetae nostro sic addictus, sicut constat ex eius epistolis, ut eum loco numinis habere videretur" (Lyons ed., 1516, fol. E, e).

60 Whose death he bewails in a poem addressed to Hermolaus Barbarus, Silvae, viII, 2. Chevalier's Répertoire (Paris, 1905) puts Cortese's death in 1499. But Hermolaus Barbarus died in 1493 .

11 Mantuan wrote a six-line epigram on his oration In die Sancti Stephani primi martyris, describing it as "breve sed magnae religionis opus." And it was through his recommendation that the speech was printed at Rome, c. 1490 .

62 Quoted by Florido Ambrogio, op. cit., 178. 
And the messages at the close seem to make the little circle complete: "saluta Beroaldum. Politianus tuus est totus." In a third letter, Sept. 19, 1490, he has enthusiastic praise for Mantuan's religious poetry, and asks for the return of his precious Greek author :

Olim ad te, optime pater, non scripsi, sed interim legi quae tu scripsisti, divina scilicet atque sanctissima illa tua poemata, in quibus ea rerum maiestas, is splendor est eloquentiae, ut certatim in illis palmam sibi vendicare verba atque sententiae videantur... hoc unum dixero, delectari me adeo lectione tuorum carminum, at fere quotidie, cum me vel taedium vel fatigatio ceperit, in illa quasi in hortum deliciarum solitus sim secedere. unde animo tanta semper oboritur voluptas ut nihil cupiat magis quam iterum fatigari, ut iterum recreetur. Philostratum de Apollonii vita, si satis illo es usus, desidero, etc. ${ }^{63}$

And the closing words are: "vale, et Beroaldum nostrum saluta." Mantuan's reply to this third letter, Oct. 1, 1490, is printed in the Bologna edition of his collected works, 1502: "Hodie mihi in sacrario nostro cum Beroaldo, ut saepe soleo, fabulanti redditae sunt litterae tuae." As for the Philostratus, he says: "Philostratum tuum prius lectione eius apprime delectatus tradidi Beroaldo perlegendum." And his letter ends: "vale, et Politianum nostrum salutato." In a letter to the younger Pico della Mirandola, Oct. 29, 1494, he says at the close: "cupio enim tecum esse. ut possemus studiorum tu meorum et ego tuorum particeps esse." And another of his letters to the same correspondent, Jan. 3, 1495, ends with the message: "bene valeat Domina tua, cui me commendo." 84 One short letter from Poliziano may be quoted entire:

Nec dubito quin amer abs te, nec exigo quod sit incommodum; sed nec officio litterarum metior amicos, quippe quod et ab inimicis praestari solet. gratulatione tun quod philosophiae sim deditus ipse mihi medius fidius ita gratulor, daturus ut operam sim quo possis in dies magis merito mihi gratulari. sed adulescens hic tuus consilio nostro si fuisset usus, magis fortasse suis rationibus consuluisset. nunc quoniam consilio noluit (ni frustra augurium) credo nec opera iam

63 1. P. Mirandulae Concordiae Comitis opera, Bologna, 1496, foll. 145,150 .

64 Ib., foll. 164, 161. In 1505 Pico submitted one of his poems to Mantuan for criticism (Florido Ambrogio, op. cit., 104). 
volet uti. verumtamen ei cupio scribas, ut a me expectet omnia, tui quidem causa. nihil enim molestius quam fuisse hunc mihi abs te frustra commendatum. vale.05

And still others who may be mentioned here are Carforo Machiavelli, of Ferrara, ${ }^{, 6}$ Bernardo Bembo, of Venice, ${ }^{, 7}$ Georgius Merula, Hermolaus Barbarus, ${ }^{\text {es }}$ Giov. Pietro Arrivabene, Bishop of Urbino, ${ }^{69}$ Pamphilo Sasso, of Modena, ${ }^{70}$ and the German scholar Thomas Wolf, Jr. ${ }^{71}$

\section{HIS WORKS}

Mantuan achieved distinction in various fields-" sacrae theologiae doctor, philosophus insignis, poeta et orator celeberrimus," as Trithemius, Abbot of Spanheim, could say in $1494 .{ }^{72}$ Trithemius mentions also his proficiency in Greek - "Latinae linguae decus et Graecae clarus interpres"and Paulus. Jovius makes especial mention of his interest in Hebrew. Indeed, Jovius says that his interest in Hebrew"insatiabilis Hebraicorum studiorum cupiditas" - interfered with the fullest exercise of his poetic gift: "ut

os Omnia opera Angcli Politiani, Venice, 1498, fol. 1, 5.

- $T$ To whom he could appeal for financial help, in the poem $D_{e}$ suscepto theologico magisterio.

6r To whom the second Parthcnice was dedicated. And it was probably out of compliment to this Bembo that the umpire of the tenth Eclogue was named "Bembus".

68 "mors Georgii Merulae... tristitia me affecit ... Hermolai et Politiani duorum illustrium virorum lamentabilis occasus attulit et mihi et omnibus litteratis grave cordolium" (Letter to Pico della Mirandola the Younger, Jan. 3, 1495).

69 To whom a poem (Silvae, 1,6 ) is sent with a gift of wine.

70 To whom Silvae, v, 5, is addressed. In the fourth book of Pamphilo's Epigrams (Brescia ed., 1499) there is a poem of eighteen lines addressed to Mantuan; it closes with the words: "o felix copia laudum, | quas aliis laudes vis dare tu tibi das." The first six epigrams of the second book are addressed to Paride Ceresara; and then conse three on the death of Polizinno, of Pico della Mirandola, and of Georgius Merula.

71 Who visited our poet at Mantua in the year 1500. An epigram printed at the end of the Silvae (Bologna ed., 1502) is entitled:In Thomam Wolfium Decretorum doctorem ac aedis $S$. Petri et Michaelis Argentinensis Decanum qui habebat Basiliscum mortuum iocus.

${ }^{2}$ Catalogus Scriptorum Ecclesiasticorum, per Johannem à Tritenheim, Cologne, 1531. 


\section{- . in excolendis Musis curam ac diligentiam remittere cogeretur." 78}

His writings were exceedingly numerous, and included both prose and verse. ${ }^{\text {T4 }}$ Sabadino, writing before 1483, mentions his work in philosophy ${ }^{75}$ and gives a list of his earlier Latin poems. ${ }^{78}$ Trithemius, writing in 1494 , has a longer list, and adds: "vivit adhuc in Italia celeberrima opinione ubique nominatus et varia conscribit."

Apart from the Eclogues, his poems include eight books of Silvae, or "subitaria carmina," 77 three books De suorum temporum Calamitatibus, ${ }^{78}$ and seven poems each entitled

${ }^{73}$ Elogia virorum literis illustrium, Basel ed., 1577, p. 117.

7t Dr. H. H. Furness, the editor of the Variorum Shakespeare, gives it as his opinion that Mantuan "wrote nothing but eclogues" $(L L L, I V, 2,95)$. But Filippo Beroaldo could say of him in 1502: "fecundus prorsus artifex, utpote qui versuum millia plurima condiderit, adeo ut Musae, ut Apollo, ut Dionysus, ut di omnes poetici nullum hoc saeculo indulgentius fovisse videantur" (Letter to the editor of the collected poems, Bologna, 1502). Lilio Giraldi says "extant illius versus paene innumerabiles" (De poetis nostrorum (cmporum). And the amount of his literary output came to be almost proverbial; cf. Les Après-Dinées du Seigneur de Cholières (1587): "Direz vous que Baptiste Mantouan n'ait esté habile homme, qu'il n'ait fait aucune chose? Ses cuvres le nous tesmoignent treslaborieux, et neantmoins il estoit carme" (Paris ed., 1879, p. 57). Indeed, his brother Tolomeo could say of him: "qui tanta conscripsit (de poetis loquor) quanta nemo alius Latinorum" (De licentiis antiquorum poetarum, Lyons ed., 1516, fol. Kk, ii).

75 " El quale, seguendo in li studii della sacra philosophia la doctrina del subtilissimo Scoto, ha scripto in quella opre eximie et prestante" (Novella LXI).

70 "El Suburbano, la Presidentia de l' oratore et del poeta, Lociamo, la Morte contemnenda, el Cola, la Porreta, opre tutte scripte et dedicate al suo carissimo Refrigerio, similmente la Calamità di nostri tempi, la Vita della regina di cieli et altre sue excellentissime opre, quale sarebbeno troppo lungo a numerare."

77 The Silvac are arranged in eight books in the Bologna edition of 1502. The Antwerp edition of 1576 nakes four bonls. Earlier editions of his collected poems had been printed c. 1499 (place and date not stated), and in 1500 (at Cologne). Another edition (incomplete, but with copious commentaries) was published by Badius Ascensius, Paris, 1513. The most complete edition of his works was issued at Antwerp in 1576.

78 Printed at Bologna in 1489 . On Jan. 29, 1480, our poet writes from Mantua to his friend Refrigerio: "Librum nostrum de calamitatibus hyemare apud nos oportuit, ut et si minus aliorum meis 
Parthenice, of which the first contains three books on the life of the Blessed Virgin, ${ }^{70}$ the second devotes three books to the story of St. Catharine of Alexandria, ${ }^{80}$ while the others deal with St. Margarita, St. Agatha, St. Lucia, St. Apollonia and St. Caecilia. ${ }^{81}$ And there are similar poems on the lives of Lodovico Morbioli, of Bologna, ${ }^{82}$ Dionysius the Areopagite (three books), ${ }^{83}$ St. George, ${ }^{84}$ St. Blaise (two books) and St. Nicholas of Tolentino (three books). ${ }^{85}$ There is a book of Epigrammata ad Falconem, ${ }^{86}$ six books entitled Alfonsus, ${ }^{87}$ five books of a Trophaeum pro Gallis

tamen notis responderet. me et illum simul videbis." Meanwhile, he quotes a sample passage, thirty-nine lines from the close of the second book: "Sylva vetus Dodona timet, gemliere Molossi | rura soli," etc. There is a MS. copy of this letter in the Library of the University of Bologna. [The poem is mentioned in the closing novel of Sabadino's Porrettane, a collection which is commonly assigned to the year 1478.]

79 Published at Bologna in $148 \mathrm{I}$-" Bononiae aeditum iii. id. Feb. M.CCCC.LXXXI," as is stated at the end of the poem in the Bologna edition of 1488-but doubtless circulated before it was "published", like Shakespeare's "sugred Sonnets among his priuate friends." The Apologeticon which is prefixed states that the author has consented to publish it, "longis precibus expugnatus." [This poem also is mentioned in Sabadino's closing novel.]

80 Written at Rome (apparently in the summer of 1488), and printed at Bologna in 1489 .

81 The Caecilia was written too late to be included in the great Bologna edition of 1502 . It was printed at Milan in 1507.

82 Dedicated to Innocent VIII (1484-92).

83 Here, as often, identified with the holy martyr of Gaul, Dionysius, the first Bishop of Paris. The poem is dedicated "ad Iafredum Carolum Mediolani Vicecancellarium et Delphinatus Praesidem." It was printed at Milan as early as 1506 .

84 Dedicated to Gian Giacomo Trivulzio, Grand Marshal of France; printed at Milan as early as 1507 .

85 First printed at Milan in 1509; the dedication is dated, Mantua, July 20, 1509.

80 Printed at Bologna (along with the two poems on Roberto da San Severino) in 1489 .

87 A theological poem, which describes the journey of a young Alfonsus through Purgatory and the Terrestrial Paradise. There is a brief and rather vague account of the conquest of Granada (1492) at the beginning of the sixth book. In the fifth book (Bologna ed., 1502 , fol. $303, \mathrm{~b})$ there is a reference to the death of the poet's father (early in 1494). 
expulsis, ${ }^{88}$ an Obiurgatio cum exhcitatione ad capienda arma contra infideles ad Potentatus Christianos, ${ }^{\circ 0}$ an Exhortatio ad Insubres et Ligures, six books entitled Agellaria, 90 a short poem Ad Iulium Secundum Pont. Max., ${ }^{21}$ a poem De bello Veneto anni 1509, and twelve books De sacris diebus which set forth and explain the various Saints' Days of the Roman year. ${ }^{22}$

Of his prose works, the most popular seem to have been the $D e$ vita beata $^{93}$ and the three books $D e$ patientia. ${ }^{94}$

88 Which deals with events of the years 1495 and 1496 . In the second book (Bologna ed., 1502, fol. 336) there is a reference to the death of Charles VIII (April 7, 1498).

89 Printed at Milan in 1507.

90 Dedicated to Don Gonzalo Hernand y Aguilar ("il Gran Capitano"); quoted in Tolomeo's Apologia, c. 1508 (Lyons ed., 1516, fol. $F f$, ii).

91 Which refers to events of the year 1506.

92 Dedicated to Leo X (crowned Mar. 11, 1513), and first printed at Lyons in 1516. Among the later poems printed at Lyons in 1516 there are two choruses from an unfinished tragedy. These were printed at Milan in 1511 , along with the Vitae suae Epitome; there is a copy in the Library of the University of Bologna. In a letter printed in this edition Mantuan writes to Antonius Sabinus, of Imola: "Dum pridem Juderem uitae meae Epitomen Ant: Sab: vir. litteratiss. tu Mediolano ueniens me reuisisti. Tibi ergo tanquam hospiti: pro xeniolo hospitali carmen id dono: daturus libentius si esset longius atque limatius. Addo etiam duos choros ex tragoedia olim a me inchoata sed non consumata (cui nomen est Atila) tunc inter schedia mea casu repertos." Another letter is added, in which "F. Matthaeus Bandellus, C. ordinis prae." writes from Milan ("ex aedib. Gratiarum calendis decembris") urging Sabinus to have the Epitome printed.

93 Printed at Alost in 1474 .

04 First printed at Brescia in 1497 ("per Bernardinum Misintam Papiensem, iii. Cal. Iunias"). The careful article in Niceron's Mémoires (Paris, 1734), Xxvir, 123, gives the date of composition as 1498, because of the statement, III, 29, "agitur enim nunc a Christo annus millesimus quadringentesimus nonagesimus octavus." And so the text runs in Ascensius' edition, Paris, 1513. But this sentence must have been "brought up to date" by some one who printed the treatise in 1498; for both the Brescia edition of 1497 and the Venice edition of 1499 have "nonagesimus septimus." And what Mantuan actually wrote in this passage must have been something different still; for each of these early editions includes a letter from Helias Capreolus to Ioannes Taberius ("Brixiae, iiii. Nonas Decembres, 1496 ") which states that the treatise has been brought to Brescia by 
Trithemius (writing in 1494) mentions also an Introductorium subtilis Scoti, a book of "orationes elegantissimae," an Apologia pro f. Petro (in three books), ${ }^{95}$ and "epistolae multae ad diversos." Some of his later works (printed at Lyons in 1516) were, Tractatus de loco conceptionis Christi, ${ }^{98}$ De causa diversitatis inter interpretes sacrae scripturae, Epiztola contra calumniatores, Dialogus contra detractores, ${ }^{97}$ Contra cos qui detrahunt ordini Carmelitarum apologia. ${ }^{98}$

\section{HIS POPUI,ARITY}

He wrote with the greatest fluency and rapidity, ${ }^{90}$ and is even said to have published more than 55,000 verses. He tells us himself that his poem on the Blessed Virgin-a poem of about 2900 lines-was the work of two years, "duorum annorum lucubratio;" and that his 2100 lines on St. Catharine of Alexandria were written in forty daysmerely by way of improving the time in an enforced summer vacation. ${ }^{100}$ But in spite of this rapid production his writings were very popular, and he was hailed by many of

Pietro da Novellara, and asks that it be printed. The fact is, that the composition of the De Patientia extended over a considerable period of years.

95 Pietro da Novellara, who had been charged with heresy (Florido Ambrogio, op. cit., 79). The discovery, at Mantua, of another unpublished work, Tractatus de sanguine Christi (1492), is reported in the Analecta Bollandiana, xIII (1894), 71-72.

${ }^{\circ 6}$ Written in 1503: Donesmondi, Dell' Istoria Ecclesiastica di Mantova, vol. ii (Mantua, 1616), p. 93.

97 Dedicated “ad Ptolemeum Gonzagam," i. e., after Jan. 6, 1507 (S. Davari, op. cit., Io).

08 Dedicated to the Cardinal Sigismondo, "eiusdem ordinis protectorem," i. e., not earlier than 1508 (Donesmondi, op. cit., II, 110).

99 " Poema omne carptim composui, cursim absolvi, non fere aliter quam canes aiunt bibere in Aegypto" (Epistola contra Calumniatores, I.yons ed., 1516, fol. $\mathrm{Bb}$, vi).

100 "Quadruginta enim et non amplius diebus opus absolutum est, dum propter aestivum iustitium negotiis intermissis curamus otia canicularia salubriter cum aliqua studiorum fruge transigere." So, too, his three books on Dionysius the Areopagite were written in a year: "lucubrationi huic annum impendi." 
his contemporaries as a second Virgil." In 1496 Erasmus could speak of him as a "Christianus Maro," and add:

t nisi me fallit augurium, erit, erit aliquando Baptista suo concive gloria celebritateque non ita multo inferior, simnl invidiam anni detraxerint. ${ }^{2}$ habet, habet fortunatissimus Carmelitarum Ordo quo sibi placeat, quo cunctos provocet.

Even before his death, a portrait bust of him was set up at Mantua, beside one of Virgil and one of the Marquis Francesco. ${ }^{3}$ His works were carried abroad, of ten by mem-

1 Thus Sabadino could say of him (before 1483) : "che è iudicato essere emulo e, se cossì è licito dire, equiperare el divin Marone suo conterraneo" (Novella LXI). Sebastian Mlurrho could write, in the preface to his commentary on the first Parthenice (c. 1493): "eius me delectatum ingenio (quo concivem suum Andinum Vergilium facile consequitur et aequat)," etc. Trithemius considered him the equal of Cicero in prose, of Virgil in verse: "qui metro Virgilium, Ciceronem prosa aequat, ne dicam superat" (quoted in the Antwerp ed., 1576, IV, 291). Thomas Wolf, Jr., had a high opinion of the Eclogues in particular: "quae eruditorum sententia totae sunt aureae. in quibus videre licet id quod in Theocriti et Maronis carmine maxime admiramur" (Letter to Jakob Wimpfeling, Feb. 24, 1503). Filippo Beroaldo ranked him next to Virgil: "proximus longo quidem intervallo, sed tamen proximus" (Letter to the editor of the collected poems, Bologna, 1502). And Teofilo Folengo ("Merlinus Cocaius") could write-just how seriously, it is hard to say-

mons quoque Carmelus Baptistae versibus altis iam boat, atque novum Manto fecisse Maronem gaudet, nec primo praefert tamen illa Maroni, namque vetusta nocet laus nobis saepe modernis,

Macaronea, xxv, fin.

2 Letter to Henry of Bergen, Opera omnia (Leyden, 1703), III, 1783 ; P. S. Allen, Erasmi Epistolae (Oxford, 1906), 1, 163. This amazing judgment suggests that Erasmus was more concerned with Mantuan's religious tone than with his workmanship. So, in another letter (III, 808), he contrasts the Carmelite poet with the "pagan" Marullus; and in a third he writes: "malim hemistichium Mantuani quam tres Marullicas myriadas." This last letter is addressed to Jakob Wimpfeling ("Basileae postridie Purificationis. Anno XVI" "). It is apparently not included in the I.eyden edition of the Opera omuia, hut it is prefixed to Mantuan's De Sacris Dichus in the Strassburg edition of 1520 .

8 By Baptista Fiera, in 1514. They are now in the Mfuseo Patrio at Mantua. They were set on an arch which joined Fiera's house to the Convent of S. Francesco (Luzio-Renier, op. cit., 56-57). They are mentioned in Scipio Maffei's account of the Marquis Francesco, 
hers of his own order,' and promptly reprinted in many European cities. The canons of an Augustinian monastery in Westphalia could say, shortly before 1500 :

ut vere de vobis David prophetasse putetur ubi inquit, in omnem terram exivit sonus eorum et in fines orbis terrae verba corum, re vera in fines orbis terrae egressa sunt verba (super mel et favum dulciora) vatis praestantissimi sacri ordinis Carmelitarum Baptistae Mantnani. ${ }^{8}$

Annali di Mantova, XI, 6 (quoted by Florido Ambrogio, op. cit., 103): "e presso S. Francesco fu scolpita la sua immagine tra quella di Virgilio e di Battista Carmelitano con questo verso:

\section{ARGVMENTVM VTRIQVE INGENS, SI SECLA COIRENT."}

And an English traveller could report in 1608: "Over the gate of the Franciscans Church is to be seen the true statue of that famous Poet and Orator Baptista Mantuanus a Carmelite Frier borne in this Citie, who flourished Anno 1496" (Coryat's Crudities, Glasgow ed., 1905, 1, 267). Paulus Jovius has what looks like an inaccurgte story of the same monument: "Federicus autem Princeps marmoream effigiem cum laurea posuit, quae in arcu lapideo iuxta Virgilii Maronis simulacrum, pia hercle si non ridenda comparatione, conspicitur" (Elogia virorum literis illustrium, Basel ed., 1577, p. 118). And this statement received due comment from Petrus Lucius, Carmelitana Bibliotheca, Florence, 1593, fol. 15: "Ceterun quod ad eius statuam marmoream attinet, ea Mantuae (velit nolit Iovius) pie conspicitur in arcu triumphali è regione Franciscanorum monasterii, dextrum Virgilio, sinistrum Mantuano, clarissimi Mantuanorum Marchionis latus claudente, cum tali elogio: argumentum utrique ingens si saecla coirent." [The three busts are not of marble, but of terra-cotta.] Cf., further, Lilio Giraldi's remark: "quas ei statuas Mantuani erexerunt" (De poctis nostrorum temporum, ed. K. Wotke, Berlin, 1894, p. 25).

4 A letter from Badius Ascensius to the Carmelite Laurentius Burellus (Lyons, July 26, 1492) states that the latter has brought to Lyons many excellent Italian books-among them, various works of Baptista Mantuanus (Philippi Beroaldi Orationes et Poemata, Lyons, 1492, fol. 2). See, also, L. Thuasne, Roberti Gaguini Epistole et Orationes, Paris, 1903, II, 40.

- Letter to the Carmelite Prior at Bologna, printed in the edition of 1502. The date is mutilated by the printer: "anno Domini millesimo quadringentesimo pridie Nonas Februarias"; but the writers mention a Deventer reprint of the De Patientia (first printed at Brescia, 1497). C.f. Mantuan's Epistola contra Calumniatores: "leguntur ubique, libelli mei, et videntur esse totius orbis iudicio approbati; non omnes tamen, sed qui iam pridem sunt editi ac Bononiae per Benedictum Hectoris imprểssi; fere enim in totum Christianismum pervenerunt, quacumque Li.tina lingua est diffusa . . . veniunt 
And the high esteem in which he was held is pleasantly indicated in one of the Epistolae Obscurorum Virorum, II, 12 (Guilhelmus Lamp to Ortuinus Gratius, c. 1517) -an account of a journey from Cologne to Rome. The traveller stops at Mantua:

et dixit socius meus, hic natus fuit Virgilius. respondi, quid curo illum paganum? nos volumus ire ad Carmelitas et videre Baptistam Mantuanum qui in duplo est melior quam Virgilius ... et quando venimus ad Claustrum Carmelitarum, dicebatur nobis gnod Baptista Mantuanus est mortuus; tunc dixi, requiescat in pace."

But there were other critics who were less partial, or less sympathetic. The inferiority of the later Mantuan is stoutly asserted in the third Idyl of Helius Eobanus Hessus (first printed in 1509, but here quoted from the third revised edition, Frankfort, 1564) :

Cyg. ergo age, in hoc gelido postquam consedimus antro, unde pecus patet atque oculis vicinia nostris, estne aliquis gelida Faustus tibi lectus in umbra?

Phil. vidimus audaci fluidum pede currere Faustum, cui nihil invideat noster nolitque secundum Tityrus, et patria natum patiatur eadem.

$C y g$. atqui pastores quosdam contentio nuper illa diu tenuit, paribusne in carmina surgant viribus alteriusne an deferat alter honori.

Phil. ut lentas corylos damnosa securibus ilex, quantum humiles superat cornus ramosa genistas, tam meus in versu praecedit Tityrus illum qui Faustum gelida cecinit resupintis in umbra. ah, male quorundam trivialis iudicat error.

Ludovicus Vives called him "magis copiosus et facilis quam tersus et sublimitati argumentorum respondens." " In 1515

ad me crebro epistolae ex Galliis, ex Britanniis, a Germania, ex Dacia, ab oceano usque Cimbrico, quibus intelligo opuscula mea illic esse in pretio, ab omnibus legi, ab omnibus laudari" (Lyons ed., 1516, fol. Aa, viii).

- Mantuan was promptly accepted as an authority on poetical usage by "Joannes Despauterius, Ravisius Textor, Hermannus Torrentinus," and others (Florido Ambrogio, op. cit., 124). He is often quoted in a Gradus ad Parnassum printed at London, 1773. And the Christian Remembrancer for 1847 (xIv, 323) says: "and even now, in such dictionaries as Ainsworth and Young, Mantuan stands as an authority."

inc tradindis disciplinis, III (quoted by Florido Ambrogio, op. cit., 127). 
Nicole Bérault-Nicolas Beraldus-urged upon his students the importance of the ancient authors, as opposed to certain "neoterici":

Video Vergilium quoque ... jam vexari paeneque excuti e manibus, proque eo cucullatum quendam summitti bonum quidem illum rarumque et admirandum; nihil tamen.... ad Homerum Mantuanum. ${ }^{8}$

\section{Lilio Giraldi was moved to say :}

Laudo institutum piumque propositum, verum extemporalis magis quam poeta maturus. extant illius versus paene innumerabiles ex quibus apud vulgus et barbaros quosdam laudem tantam est adeptus, ut unus prope poeta et alter paene Maro haberetur. at bone Deus, quam dispar ingenium! nam ut ubique Maro perfectus, ita hic immodica et paene temeraria ubique usus est licentia, quam et magis atque magis in dies auxit. ... iuvenis ille quidem laudabilior poeta fuit; cum vero ei desedit calor ille et fervor iuvenilis, tamquam amnis sine obice extra ripas sordide diffluens coerceri non potuit. vix enim ea legere possumus, quae longius ille aetate provectus carmina scripsit. ${ }^{9}$

The great champion of Virgil, Julius Caesar Scaliger, was stirred to very vigorous language:

mollis, languidus, fluxus, incompositus, sine numeris, plebeius; non sine ingenio, sed sine arte. dum modo scribat quod in mentem venerit, edat quod scripserit, susque deque habet.

And as for the Eclogues in particular, he could express himself only by a parody of what Horace had said of Virgil:

putri atque caduco
Carmelum imbuerunt sordentes rure cicadae. 10

After this outburst we hear much less about the "pagan" and the "Christian" Virgil. One man did revive the comparison, but he was a Carmelite historian. ${ }^{11}$

- L. Delaruelle, Le Musie Belge, xull (1909), 290.

- De poetis nostrorum temporum, ed. K. Wotke, Rerlin, 1894, p. 24. . 10 Poetice, vi, 4.

11 "Veteri Maroni in paucis minor, in multis par, in plurimis aliquot parasangis superior," Petruš I.ucius, Carmclitana Bibliotheca, Florence, 159.3, fol. 13. 


\section{COMPOSITION AND PUBLICATION OF THE ECLOGUES}

The Eclogues are ten in number, making a total of 2063 lines. The author tells us, in his dedicatory epistle, that the first eight were written while he was a student at Padua, ${ }^{12}$ and that the last two were added after he had joined the Carmelite Order. He tells us, also, that he revised these youthful compositions when he was about fifty years old; and we may be sure that this revision added much to the value of the poems. But even after their revision he seems to have regarded them as a rather frivolous and unimportant piece of work; and he probably never dreamed that his ten Eclogues were to contribute more to his fame and to his influence than all the rest of his 55,000 verses.

They were first printed, at least in their revised form, in $1498 .{ }^{13}$ They were very popular from the beginning, and soon came to be widely read-not only in Italy, but in France and Germany and England. ${ }^{14}$ They were imme-

12 "Quendam libellum meum quem olim ante religionem, dum in gymnasio Paduano philosophari inciperem, ludens excuderam et ab illa aetate Adulescentiam vicaveram."

13 "Mantuae Impraessum per Vincentiū Berthocū Regiensem Anno dñi. McccclxxxxiII. sexto decimo Kalendas Octobres," etc. So the colophon of a copy in the Bibliotecs Casanatense at Rome. [The colophon of my own copy gives the same place, printer, and year, but omits the day of the month.] The dedicatory epistle is addressed to a friend at Mantua, and dated Sept. 1. Both Brunet's Manuel and Graesse's Trisor mention an edition printed at Poitiers in 1498; and both Graesse and Hain cite even an edition with a few notes by Joh. Murmellius printed at Strassburg in the same year. Graesse calls the Mantua edition a reprint of the Poitiers edition; but there was hardly time between Sept. I and Sept. 16 for an interịnediary edition to be printed abroad. Perhaps the date of the Poitiers edition was only inferred from the date of the dedicatory epistle; a copy described in Pellechet's Catalogue giniral, 1, 437, is "s. d. (1498?)." [The "ndnotamenta" of Murmellius were included in a letter addressed to Paulus Ruremundensis (printed in full in a Deventer edition of the Eilogu's, 1510). This letter is mainly a criticism of the commentary of Ascensius; and was certainly written later than 1498.]

14 They were printed at Erfurt in 150I, at Bologna, at Brescia, and at Paris in 1502, at Venice and at Strassburg in 1503. at Deventer in 1504, in 1505. and in 1510, at Tübingen in 1511, at london in 1519 , etc., etc. In 1504 they were printed at Florence, in a handsome Giuntine volume: "F.clogne Vergilii. Calphurnii. Nemesiani. Francisci Pe. Ioannis Boc. Inan. hap. Mă. Pomponii Gaurici." 
diately provided with a commentary, by Iodocus Badius Ascensius, ${ }^{15}$ and for nearly two hundred years they were commonly used, both on the Continent and in England, as a text-book in schools.

\section{THEIR USE AS A SCHOOL-BOOK}

Their use as a school-book is attested by countless editions of Ascensius' commentary, ${ }^{16}$ but it is also definitely stated at times, or clearly implied. There is a letter of Thomas Wolf, Jr., to Jakob Wimpfeling, written at Strassburg, Feb. 24, 1503, which speaks of a school edition of a thousand copies: ${ }^{17}$

G. Brunet states that from 1500 to 1536 they were printed 22 times (Dictionnaire de Bibliologie Catholique, Paris, 1860, col. 1011). "On compte de plus 4 éditions des Opera Omnia de cet auteur c. 88 éditions de divers de ses ouvrages."

15 Both Graesse and Hain say that this commentary was printed at Strassburg in 1500 . It was printed at Paris in 1502 (with a dedicatory epistle dated March 27), at Strassburg in 1503, at Deventer in 1504, at Tübingen in $15 \mathrm{Ir}$, etc., etc. It was printed in London at least as late as 1676, and at Cologne at least as late as 1688. Murmellius criticized it, and with good reason, as giving the schoolboy much unnecessary help while leaving some real difficulties unexplained; "deinde autem cum tardiusculis ingeniis totum se accomodat: \& quasi tenellis infantulorum rostris premansum cibum inserit magis obesse studiis quam prodesse iudicatur" (Letter to Paulus Ruremundensis, cited above).

16 Another copious commentary (now very rare) was published by Andreas Vaurentinus (of Lavaur, near Toulouse) in 1519. There is a copy of a revised edition, Lyons, 1529, in the Library of the University of Ferrara: "Habes hic candide lector uberrima commentaria Andree vaurētini in buccolica fratris Baptiste Mantuani carmelite Theologi et poete celeberrimi correcta ac emendata. Addita sunt preterea glossemata in prima Buccolica que culpa impressorum lemovicorum ( $\mathrm{sic}$ ), et que summopere utilia erant. Necnon et Ioannis coronei Carnutensis Annotamenta perquam utilia novissime (jut ab eiusdem Coronei scholaribus asseritur) superaddita : cum annotationibus Remundi langano de alta Ripa in margine positis : et nuni antea impressis," etc., etc. In the Biblioteca Nazionale at Naples there is a later edition of the same commentary, published at Lyons (by a different printer) in 1536: "Bucolica Baptistae Mantuani, diversis diversorum coñentariis utilissime declarata," etc.

17 Wolf's letter and Wimpfeling's reply are quoted in the Tübingen edition of the Eclogues, 1515. Wimpfeling preferred the Eclogues of Mantuan to those of Virgil, "propter Latinitatis copiam, propter 
Aeglogas Baptistae Mantuani (sicut audio) tradidisti Ioanni Preusz chalcographo communi nostro amico, ut in mille exemplaria transcriptae latissime diuulgentur. debet profecto tibi plurimum Germana iuuentus, quae diligentia tua multis doctorum nirorum monumentis facta est opulentior. semper enim ex officina tua literatoria aliquid depromis quod iuuet, quod delectet, quod linguas iunenum reddat politiores.

And Wimpfeling's reply, dated March 1, 1503, emphasizes the fitness of Mantuan for school use:

Baptistam Mantuanum extollo, tum in poematibus suis tersis et puris, quae absque ueneno a maturo praeceptore iuuentuti tradi possunt, tum quod amor poeticae in eo non extinguit studium sacrae paginae et philosophiae, nam ex eius libello de patientia magnum eum et philosophum et theologum esse liquido constat.

About 1508 a schoolboy at Schlettstadt wrote to his father: "Wisse, dass unser Magister des Morgens früh den Alexander mit uns treibt; um 9 Uhr lesen wir einige Gedichte aus Horaz, Ovid, u. s. w.; nach 10 Uhr lesen wir im Mantuanus." 18 In 1533 the Eclogues were used as a school-book at Wittenberg; in 1535 Mantuan was prescribed by school orders at Braunschweig; and about the same time he was read in the schools at Nordlingen, Memmingen, and Emmerich. ${ }^{10}$

In St. Paul's School, London, he was prescribed by statute, in 1518.20 For Colet would have his "scolers" taught in "goode auctors suych as haue the veray Romayne eliquence joyned withe wisdome, specially Cristyn auctours that wrote theyre wysdome with clene and chast laten other in verse or in prose." And among such authors he names "lactancius prudentius and proba and sedulius and Juuencus and Baptista Mantuarus." This passage may suggest some of Mantuan's religious poems rather than the

stili planam dulcedinem, propter utiliora argumenta, propter pudicitiam et honestatem," Dialr. de proba puerorum instit., vi (quoted by G. Knod, Aus der Bibliothek des Beatus Rhenanus, Schlettstadt, 1889, p. 10).

18 G. Knod, op. cit., 17.

19 Monumenta Germaniae Paedagogica, 1, 48, 544 ; vil, 426.

20 J. H. Lupton, Life of Dean Colet, London, 1887, p. 279. 
Eclogues, ${ }^{21}$ though some of the latter may very well have been included. And there may be a like uncertainty in the statute which prescribed "B. Mantuanus, Palingenius, Buchanani Scripta, Sedulius, Prudentius" for the Free Grammar School of St. Bees in Cumberland, in 1583.22 But the Eclogues are specifically fixed by school orders at

21 About 1493 Seb. Murrho wrote a commentary on the first Parthenice: "cum maxime trivialium Judorum magistris consulere statuerim iuvenilique aetati." Before 1498 Alexander Hegius wrote a commentary on some of the poems for his school at Deventer ( $L$. Geiger, Renaissance und Humanismus, Berlin, 1882, p. 392). About 1502 Filippo Beroaldo says of Mantuan: "nec solum habetur in manibus et ediscitur, verum etiam in scholis enarratur, et inde saluberrima tirunculis dictata grammatistae praescribunt" (Letter prefixed to the Bologna edition of the collected poems, 1502). In one of the Epistolae (XLI) of Ravisius Textor, one of Mantuan's epic poems is mentioned as a school-book: "testatus Lucanum, Silium, et Statium, ut duriusculos; Mantuani Carmen, ut paulo flaccidius, a plerisque non usquequaque probari" (London ed., 1683, p. 33). Cf. also the Elegiae Morales of Johannes Murmellius (printed in 1507), I, i, 53-60:

nobilis aethereo plenus Baptista furore heroicam inflavit me moderante tubam; virgineis libros infersit laudibus almos, lucida belligeros vexit in astra duces. ille graves huius deflevit temporis aestus, ille Cupidineos vitat ubique iocos. ergo frequentatis divina poemata ludis dictantur summi non sine laude viri,

and III, $i, 47-52$ :

gloria Carmeli veteres Baptista poetas gymnasiis pellens pulpita celsa tenet. dum pia virginibus soiveniu, vota sacratis, dum populi flentes tristia fata gement, crescet honor vatis maiorque videbitur annis, rectius arbitrium posteritatis erit

(Münster ed., by A. Bömer, 1893, pp. 9, 75). In a letter of May I, 1518, Jakob Wimpfeling suggests a school edition of the De Sacris Diebus. And about a hundred years later Mantuan is mentioned as being a favorite school author in Spain: "onde l'opere sue poetiche leggonsi in Ispagna a' gioueni publicamente nelle scuole d' humanità (per quanto hò udito dire) come in Italia si fanno quelle di Virgilio," Donesmondi, Dell' Istoria Ecclesiastica di Mantova, II (1616), I2I (cited by Luzio-Renier, op. cit., 68).

22 T. Spencer Baynes, Shakespearle Studies, London, 1894, p. 174 
the King's School, Durham, in $.1593 ;^{23}$ they were in use in the Free School of St. Helens, c. $1635 ;{ }^{24}$ and they were recommended for the third form in Charles Hoole's New Discovery of the Old Art of Teaching School, 1660:

For Afternoon lessons on Mondayes and Wednesdayes let them make use of Mantuanus, which is a Poet, both for style and matter, very familiar and gratefull to children, and therefore read in most Schooles. They may read over some of the Eclogues that are less offensive than the rest, takeing six lines at a lesson, which they should first conmit to memory, as they are able, etc. ${ }^{25}$

And as Hoole records, they were used in the Rotherham Grammar School (in the fourth form) before he became head master:

For afternoon lessons they read Terence two dayes, and Mantuan two dayes, which they translated into English, and repeated on Fridayes, as before. ${ }^{26}$

Julius Caesar Scaliger complained that some teachers actually preferred them to the Eclogues of Virgil: " hoc propterea dico, quia in nostro tyrocinio literarum triviales quidam paedagogi etiam Virgilianis pastoribus huius hircos praetulere." ${ }^{27}$ There is a similar complaint in the preface of Thomas Farnaby's edition of Martial, London, 1615: "quando ipsis paedagogulis Fauste precor gelida sonet altius quam Arma virumque cano." And Dr. Samuel Johnson states that "Mantuan was read, at least in some of the inferior schools of this kingdom, to the beginning of the present century." 28

23 Foster Watson. The Beginnings of the Teaching of Modern Subjects in England, London, 1909, p. 187.

24 Id., The English Grammar Schoc's to s660, Cambridge, 1908, p. 486.

25 This was an exercise in "metaphrase," T. Spencer Baynes, op. cit., 186. Professor Baynes says (p. 16I) that Hoole's New Discovery "was not published till 1659 , but, as the title-page states, it was written twenty-three years earlier." Professor Watson says, "published in 1660, written twenty years earlier."

26 T. Spencer Baynes, op. cit., 172.

27 Poetice, vi, 4.

28 Lives of the Poets, Ambrose Philips. 
In 1579, Thomas Lodge could say, in his Defence of Poetry: "Miserable were our state yf we wanted those worthy volumes of Poetry: could the learned beare the losse of Homer? or our younglings the wrytings of Mantuan?" And so Drayton tells us that, when he expressed a boyish wish to become a poet, his tutor

\section{began \\ And first read to me honest Mantusn, Then Virgil's Eclogues."}

It will be observed that Shakespeare's quotation from Mantuan is put into the mouth of a schoolmaster; and it may be suggestive for our estimate of Holofernes' learning that he quotes the first line of the first Eclogue-as it were, the opening phrase of his First Latin Reader. At any rate, the same phrase is used to indicate a very little learning in one of Gabriel Harvey's gibes at poor Greene: "he searched euery corner of his Grammer-schoole witte (for his margine is as deepelie learned as Fauste precor gelida)." so And it is used in the same way in one of the pleasant tales of Bonaventure des Periers: "Il y avoit un prebstre de village qui estoit tout fier d'avoir veu un petit plus que son Caton. Car il avoit leu De Syntaxi et son Fausti pricor gelida." "s1

\section{QUOTATIONS FROM THE ECLOGUES}

And this common use as a school-book may help to explain some other references in English, French, and German authors.

Ecl. I, 118 is quoted in Stephen Gosson's Schoole of Abuse (1579): "Now if any man aske me why my selfe haue penned Comedyes in time paste, and inueigh so egerly against them here, let him knowe that Simel insanivimus omnes. $^{32}$

Ecl. I, 52, "nec deus, ut perhibent, Amor est," is quoted

29 To my dearly loved Friend, Henry Reynolds, Esq., of Poets and Poesy.

so Foure Letters (1592), ed. Grosart, I, 195.

31 Nouvelles Recréations et joyeux Devis, Nouvelle XL.

32 Arber's reprint, London, 1868, p. 41. 
in on: of Gabriel Harvey's letters to Spenser (1579). .3 $^{33}$ And the whole line appears as a motto on the title-page of Alcilia : Parthenophil's Loving Folly (1595):

Nec Deus (ut perhibent) amor est, sed amaror et error.84

In Robert Greene's Tritameron of Love (ed. Grosart, III, $100)$ there is a mention of "Mantuans principle ... that weal is neuer without woe, no blisse without bale, ech sweete hath his sower, euery commodity hath his discommodity annexed." This alludes to Ecl. II, 25-26,

commoditas omnis sua fert incommoda secum, et sorti appendix est illaetabilis omni.

In the Historie of Orlando Furioso, II, 1 (671), Greene quotes $E c l$. Iv, 110,

femineum servile genus, crudele, superbum;

and in the 'Epistle to the Gentlemen Schollers of both Universities,' prefixed to his Mourning Garment (Ix, 124), he quotes the "semel insanivimus omnes" of $E c l$. I, 118. In the first part of Mamillia (II, 107) he has an allusion to the famous diatribe against women, in the fourth Eclogue: "I would correct Mantuans Egloge, intituled Alphus: or els if the Authour were aliue, I woulde not doubt to perswade him in recompence of his errour, to frame a new one." And in the second part (II, 226) he returns to the same subject: "yea the railing of Mantuan in his Eglogs, the exclaiming of Euripides in his 'Tragedies, the tants of Martiall, and prime quippes of Propcrtius, are more of course then cause, and rather inforced by rage than inferred by reason."

The "semel insanivimus omnes" of Ecl. I, 118, is twice quoted by Thomas Nashe-in the Prologue to Summer's Last Will and Testament (1600), and in Have with you to Saffron-Walden (1596): "and he replied with that wetherbeaten peice out of the Grammer, Semel insanivimus omnes, once in our dayes there is none of vs but haue plaid the

33 Grosart's edition, I, 25.

34 Arber's English Garner, iv (1882), 253. 
ideots." And in the Anatomie of Absurditie (1589), Nashe has his allusion to the fourth Eclogue:

To this might be added Mantuans inuectiue against them, but that pittie makes me refraine from renewing his worne out complaints, the wounds wherof the former forepast feminine sexe hath felt. I, but here the Homer of Women hath forestalled an obiection, saying that Mantuans house holding of our Ladie, he was enforced by melancholie into such vehemencie of speech, and that there be amongst them as amongst men, some good, some badde, etc. ${ }^{35}$

The story of Amyntas, Ecl. II-III, is introduced, as thoroughly familiar matter, in the first eclogue of Francis Sabie's Pan's Pipe (1595), 11. 76-93. ${ }^{36}$ And it seems to be alluded to in Thomas Randolph's Eclogue occiasioned by Two Doctors disputing upon Predestination:

Love-sick Amyntas, get a philtre here,

To make thee lovely to thy truly dear.

The motta of one of Bishop Hall's Satires (1598), vi, 1, "Semel insanivimus," comes from Ecl. I, 118; and in the same satire we have the lines,

As did whilere the homely Carmelite,

Following Virgil, and he Theocrite.

35 Ed. R. B. Mckerrow, London, 1904, I, 12. This seems to be an inaccurate reference to a passage in Robert Greene's Mamillia (ed. Grosart, 11, 107): "I would correct Mantuans Egloge, intituled Alphus ... for surely though Euripides in his tragedies doth greatly exclaim against that sexe, yet it was in his choller, and he infered a generall by a particular, which is absurd. He had an euyll wife, what then?" Mr. McKerrow explains Nashe's phrase “Mantuans house holding of our Ladie" to mean "his wife having the upper hand of him, and ruling his household," and quotes Ascham's Scholemaster (ed. Wright, p. 2105), "if the house hold of our Lady." And he very justly insists that Greene is here referring to the wife of Euripides, "and not to Mantuan's wife at all." There is a bit of gossip in one of the novels of Bandello (1II, 52) which offers a little different explanation of Mantuan's bitterness: "Intendo anche che il mio conspatriotta, il poeta carmelita, ha fatta un' ecloga a ، vituperio delle donne, ove generalmente biasima tutte le donne. Ma sapete ciò che ne dice Mario Equicola segretario di madama di Mantova? Egli afferma che il nostro poeta era innamorato d' una bella giovane, e che ella non lo volle amare; onde adirato compose quella maledica ecloga" (quoted by Luzio-Renier, op. cit., 66).

${ }^{30}$ Reprinted, by J. W. Bright, in Modern Philology, vil (1910), 446. 
The motto at the end of Three Pastoral Elegies, by William Basse (1602), is taken from $E c l$. 1, 9-10:

quando vacat, quando est iucunda relatu, historiam prima repetens ab origine pandam.

Ecl. v, 63-64:

sidera iungamus, facito mihi Iuppiter adsit; et tibi Mercurius noster dabit omnia faxo,

is the motto on the title-page of Thomas Middleton's Familie of Love (1607). And Ecl. III, 87, " regia res amor est," is set in like manner on the title-page of Richard Brome's The Queenes Exchange.

The phrase "semel insanivimus omnes," Ecl. 1, 118, served as the motto of Samuel Nicholson's Acolastus his After-witte (1600); ${ }^{37}$ and it is quoted in The Return from Parnassus (printed in 1606), Iv, 2.

The quotation in Wily Beguiled (printed in 1602), ,38 "optatis non est spes ulla potiri," comes from Ecl. I, 53.

In Drayton's Owl (1604), the playful mention of the lark,

And for his reverence, though he wear a cowl,

alludes to $E c l$. vir, 4,

bardocucullatus caput, ut campestris alauda ;

and the passage in the same poem,

O moral Mantuan, live thy verses long,

Honour attend thee, and thy reverend song!

Who seeks for truth (say'st thou) must tread the path

Of the sweet private life, ....

For adulation, but if search be made,

His daily mansion, his most usual trade,

Is in the monarch's court, in princes' halls,

Where goodly zeal he by contempt enthralls, etc.,

87 J. P. Collier, Biographical Account of Early English Literature, III, 58.

8 Dodsley's Old English Plays, ed. Hazlitt, Ix, 232. 
seems to refer to Ecl. v, $166 \mathrm{ff}$. In his Epistle of Mrs. Shore to Edward IV. there is an allusion to the fourth Eclogue:

Nor are we so turn'd Neapolitan,

That might incite some foul mouth'd Mantuan

To all the world to lay out our defects,

And have just cause to rail upon our sex, etc.

In Thomas Heywood's Challenge for Bcautic, 1, 1, there is yet another allusion to the fourth Eclogue. Here the "proud Queen" Isabel says, of the compliments due to women :

Such as would sive us our full charncter

Must search for Eppithites und studie phruse;

and the honest I.ord Bonuvida replies:

Examine but plaine Mantuan, and hee'l tell you, what woman is.

The phrase "melior vigilantia somno," $E c l .1,5$, is quoted in William Martyn's Youth's Instruction (1612). ${ }^{\text {so }}$

Ecl. III, 81, is quoted, freely, in Beaumont and Fletcher's Wit at Several Weapons, 1, 2: Ut nocte mecum pernoctat egestas, luce quotidie paupertas habitat. This is quoted by "Priscian, a poor Scholar"-much as Shakespeare's quotation from Mantuan is put into the mouth of "Holofernes, a schoolmaster." 40

In Witt's Recreations, the phrase "sorte tua contentus," $E c l$. v, 46, is used as the title of two separate epigrams. And the "semel insanivimus," or "semel insanivimus omnes," of $E c l$. I, 118, serves as the title of two others.

In Burton's Anatomy of Melancholy there are a whole score of quotations. The phrase "semel insanivimus omnes," Ecl. 1, 118, appears three times. The chapter on Symptoms of Love-Melancholy has eight quotations:

39 Report of U.S. Commissioner of Education for 1904, 1, 664.

10 :Larivey has some claim to the title of European master of eccentric pedantry on the comic stage"; Sidney Lee, The French Renaissance in England, Oxford, 1910, p. 423. Was the name of Larivey's pedant M. Josse a delicate compliment to Iodocus Badius Ascensius-Josse Bade? 
Ecl. I, 38 ; 1, 100; 11, 104-6; 1, 14-18; II, 107-8; 1, 114-15 ; 1, $47 ; 1,108$. The chapter on Artificial Allurements of Love quotes three passages: $E c l .1,104 ; 1,73 ; \mathrm{IV}, 218$. And the first of thes: is introduced as very familiar matter; "and Galla's sweet smile quite overcame Faustus the Shepherd :

me aspicien motis blande subrisit ocellis."

The section on Beauty as a Cause of Love-Melancholy quotes, and translates, Ecl. 1, 48-51, "ludit amor sensus," etc. :

Love mocks our senses, curbs our liberties,

And doth bewitch us with his art and rings,

I think ome devil gets into our entrnils,

And kindles conlx, and henver our souls from the hinges.

Other scattered quotatione in the earlier part of Burton's work are, Ecl. 1, 71; 1, $174 ; 1,61$; v, 46.

Indeed, some of Mantuan's phrases are repeated so often that they have earned a place in our dictionaries of Latin quotations. So, in particular, the "semel insanivimus omnes," of $E_{c l} l$. I, 118, which has acquired a special interest from a passage in Boswell's Life of Johnson:

When I once talked to him of some of the sayings which every body repeats, but nobody knows where to find, ... he told me that he was once offered ten guineas to point out from whence Semel insanivimus omnes was taken. He could not do it; but many years afterwards met with it by chance in 'Johannes Baptista Mantuanus.'

A few other references may be added here, to illustrate the popularity of Mantuan's Eclogues in England.2 $\mathrm{He}$ is mentioned in the prologue to the Egloges of Alexander $z$ Barclay (c. 1514) - named after Theocritus and Virgil-

As the moste famous Baptist Mantuan, The best of that sort since Poetes first began.

11 London ed., $1890, \mathrm{III}, 266$.

12 The first nine were translated into English fourteeners by George Turbervile, in 1567. And this translation was reprinted in 1572, 1594, and 1597. "The whole ten Eclogues did not find a translator till 1656 when Thomas Ilarvey published a version in decasyllabic couplets" (Walter W. Greg, Pastoral Poetry and Pastoral Drama, London, 1906, p. 78). 
His name appears again in 'E. K.'s' famous epistle to Gabriel Harvey (1579). He is mentioned in William Webbe's Discourse of English Poetrie (1586): "Onely I will add two of later times, yet not farre inferiour to the most of them aforesayde, Pallengenius and Bap. Mantuanus." And again (of pastoral poetry) Webbe says: "After Virgill in like sort writ Titus Calphurnius and Baptista Mantuan." In George Puttenham's Arte of English Poesie (1589), I, 18, we read: "These Eglogues came after to containe and enforme morall discipline, as be those of Mantuan and other modern Poets." In Francis Meres' Sketch of English Literature (1598) Mantuan is named among the "Neoterics" (Jovianus Pontanus, Politianus, Marullus Tarchionota, etc.) who "have obtained renown and good place among the ancient Latin poets." And in the same sketch it is stated that "Theocritus in Greek, Virgil and Mantuan in Latin, Sannazar in Italian, . . . are the best for Pastoral."

In Germany, the Eclogues are quoted as early as 1508, in Heinrich Bebel's Allagia Germanica, No. 246: "Catti invalidi longius vivunt; dicitur in eos qui minus grati diu vivunt, dum optati saepe cito moriantur, nam:

si qua placent abeunt: inimica tenacius haerent." 43

This is Ecl. I, 174. And in the Lamentationes novae Obscurorum Reuchlinistarum (1518), No. 118, there is an echo of the dedicatory epistle: "Quid, obsecro, tanti facis philosophi in physicis acnigmata, quac Ocdipodes ipse non solveret?"

In the Pappa Puerorum of Johannes Murmellius (1513) the sentence, "Vadam ad levandum ventrem post dumeta," is probably due to $E c l$. IV, 87. And two of his "protrita proverbia " are, "semel insanivimus omnes" (Ecl. I, 118), and "amor est amaror" (cf. Ecl. I, 52).44

13 Ed. Suringar, Leiden, 1879, p. 69. Other quotations may be found in Wander's Deutsches Sprichwörter-Lexicon, Leipzig, 1867, e. g., under 'Erfahrung,' Ecl. Ix, 195, "facit experientia cautos"; under 'Liebe,' Ecl. I, 48-49, "ludit Amor sensus," etc.; under 'Bauch,' Ecl. 1, 61, " qui satur est pleno laudat ieiunia ventre."

44 Ed. A. Bömer, Münster, 1894, pp. 16, 34. In his Scoparius (1517), Murmellius discusses the "patinam Aesopi" and the "clipeum Minervae" of $\mathrm{Ecl}$. v, 98 (ed. Bömer, p. 50). 
In the second Eclogue of Euricius Cordus there is a complimentary reference to Mantuan, and his first Eclogue:

omnes non unum facitis quotcumque poetam qualem ego in Ausoniis audivi finibus olim.

One of the singers professes to have seen him at Mantua during the year of jubilee:

hic nivei dominus pecoris prope flumina pastor ad viridem recubans in opaco frigore clivum sustulit argutos altum super aethera cantus, quos non fagineae superent dulcedine glandes,

- non mixtus butyro favus, et non molle colostrum.

Aeg. iam scio qui fuerit; quo, dic, indutus amictu?

Mop. quo pecus, hoc etiam fuit illi palla colore.

$\mathrm{Aeg}$. Candidus est, gelida qui Faustum lusit in umbra,

ut retulit veteres Gallam quibus arserat ignes.

$M o p$. nunc age, dic, isto tibi quid de vate videtur?

Aeg. omnia consequitur magnas per ovilia laudes. ${ }^{45}$

There are eleven quotations in the Iocoseria of Otho Melander: Ecl.vi, 203-207; vi, 181-182; vi, 198-202; v, 136; II, 91-93; I, 48-51; I, 81-84; I, 114-116; II, 66-67; X, 193; II, 66-67 (again). ${ }^{48}$

Ecl. Iv, $110 \mathrm{ff} .$, is quoted, and refuted, in one of the epigrams which go under the name of Crepundia Poctica (ed. 1648, p. 54) :

Cur mala femineo de sexu, Rustice, profers, et bona quae confert non reticenda taces?

fimineum est seriile genus, crudele, superbum? nobilis et clemens Virgo humilisque data est. lege, modo, ratione caret, rectum abicit, inquis? at placet huic rectum, lex, ratio atque modus. cxtremis ea gaudet, ais, mediocria vitat? haec extrema fugit, sed mediocre tenet. decepit Indaea virum prolemque Rebecca? concipit alma virum Virgo paritque Deum. E'a genus nostrum felicibus expulit arvis? in meliora facit nos ut eamus AvE. cur bona femineo de sexu, Rustice, celas, et mala si qua facit non referenda refers?

4. Leipsic ed., 1518.

16 Frankfort ed., 1626, pp. 2, 14, 36, 133, 137, 161, 177, 423. 
In France, ${ }^{47}$ Ecl. IX, 24-31, is quoted and discussed by Ravisius Textor, Epistolae, 42, 43. ${ }^{48}$ And the Eclogues and other poems of Mantuan are occasionally quoted in the same writer's Officina and Epitome.99

There are four quotations in the learned commentary which Benedictus Curtius composed on the Arrêts d'amour of Martial d'Auvergne: ${ }^{50} \mathrm{Ecl}$. I, 114-116; vI, 198-202; III, 83-87 ; I, 118 ("Et Baptista Mantuanus nos insanivisse omnes semel dicit: et ipsum cucullatum insanivisse eius opera ostendunt").

Fontenelle was offended by the coarseness of $E c l$. Iv, 87 : “on ne s'imaginerait jamais quelle précaution prend un autre berger avant que de s'embarquer dans un assez long discours." And he had little sympathy with those who had compared Mantuan with Virgil: "quoique assurément il n'ait rien de commun avec lui que d'être de Mantoue." 51

In Italy, we have a summary of the first three Eclogues in Mario Equicola's Libro di Natura d'Amore (Venice ed., 1554, pp. 68-69).

\section{IMITATIONS OF THE ECLOGUES}

The Eclogues were very promptly imitated in England, in the five Egloges of Alexander Barclay (c. 1514)..$^{62}$ Barclay's fourth is a paraphrase of Mantuan's fifth; his fifth is a paraphrase of Mantuan's sixth, with the insertion of a. long passage taken from Mantuan's seventh (9-56). And even in his other eclogues a part of the pastoral setting is borrowed from his Carmelite model. ${ }^{53}$ The beginning of

${ }^{47}$ The ten Eclogues were translated into French by Michel d'Amboise, Paris, 1530, and by Laurent de la Gravière, Lyons, 1558 .

48 London ed., 1683, pp. 35, 36. etc.

40 Venice ed., 1566-1567, I, 23, 88; II, I26; III, I3, 15, 20, 22, 23,

60 Paris ed., 1566, pp. 137, 574, 725, 728.

12 Discours sur la nature de l'Églogue.

B2 Printed in Publications of the Spenser Society, No. 39 (1885).

s3 For details, see O. Reissert, Neuphilologische Beiträge, Hannover, 1886, pp. 14-31; W. P. Mustard, Modern Language Notes (1909), xxIv, 8-9. One item which is taken bodily from Mantuan (vII, 42-54) is a "detailed notice of a mural painting in Ely Cathedral, which has long since disappeared"-a painting which struck 
the first is due to the beginning of Mantuan's third (1-37). and the punning allusion to Bishop Alcock (p. 5) is adapted from Mantuan's allusion to Falcone de' Sinibaldi (Ix, $213 \mathrm{ff}$.). The beginning of the second repeats a passage from Mantuan's second (1-16) ; the beginning of the fourth reminds one of Mantuan's ninth (117-119) and tenth $(137-141,182-186)$; and toward the close of the fifth (p. 45) there is a passage which comes from Mantuan's second (66-78).

In Barclay's ' Prologe,' too, there is an interesting parallel to a passage in Mantuan's dedicatory epistle. This epistle, dated 1498, begins with a playful riddle:

Audi, o Pari, aenigma perplexum, quod Oedipodes ipse non solueret. ego quinquagenarius et iam canescens adolescentiam meam reperi, et habeo adolescentiam simul et senectam.

The explanation is, that in the previous year he had found a certain youthful composition of his own, consisting of eight eclogues and, "ab illa aetate," entitled Adolescentia. And now he sends it forth again, in revised and augmented form. But history repeats itself, and it was not long before Barclay could report a similar experience:

But here a wonder, I fortie yere saue twayne

Proceeded in age, founde my first youth agayne.

To finde youth in age is a probleme diffuse,

But nowe heare the truth, and then no longer cause.

As I late turned olde bookes to and fro,

One little treatise I founde among the mo:

Because that in youth I did compile the same,

Egloges of youth I did call it by name.

And now he too has "made the same perfite"-

Adding and bating where I perceyued neede. ${ }^{\mathrm{s}}$

one of Barclay's editors as "very curious," Publications of the Percy Sociefy, xxit, 43. It is cited also in the Dictionary of National Biography (s.v. Alexander Barclay) as a proof that Barclay's Egloges were written at Ely.

Bt It is interesting to notice that Professor ten Brink found in these lines the explanation of a peculiar quality of Barclay's Egloges; namely, their combination of the freshness of youth with the maturity of manhood: "So erklärt es sich, wenn diese Dichtungen in höherem 
In 1563 we have eight English eclogues by Barnabe Googe. Here again the model is Mantuan, though there is very little verbal imitation or borrowing in detail. The lines at the close of Ecl. Virl,

and Phoebus now descends,

And in the Clowdes his beams doth hyde, which tempest sure portends,

come from the close of Mantuan's third,

et sol se in nube recondens, dum cadit, agricolis vicinos nuntiat imbres.

And perhaps the ram whose battered condition symbolizes his owner's fortunes ( $E c l$. III) should be compared with Mantuan's ram, Ecl. IX, 46-47:

hic aries, qui fronte lupos cornuque petebat, nunc ove debilior pavidoque fugacior agno est.

Spenser's Shipheards Calender (1579) owes a large debt to Mantuan, especially in the eclogues for July, September, and October. This was pointed out by F. Kluge, Anglia. III, 266-274, and O. Reissert, $i b$. Ix, 222-224; and it is now set forth in C. H. Herford's edition of the poem. Perhaps one further parallel should be suggested; compare 'October,' 100-101,

The vaunted verse a vacant head demaundes $5 \mathrm{~s}$

$\mathrm{Ne}$ wont with crabbed care the Muses dwell,

with Ecl. v, 18-19,

Grade als andere Werke Barclay's jugendliche Frische mit männlicher Reife in sich vereinigen" (Geschichte der englischen Litteratur, Strassburg, 1893, 1I, 455). And Barclay's borrowed experience is still accepted as fact in the new Cambridge History of English Literature, III (1909), 62.

55'E. K.' says that line 100 "imitateth Mantuanes saying, " $v a-$ cuum curis divina cerebrum Poscit." But the 'saying' is hard to find; it is not in the Bologna edition of the collected poems, 1502. or in Ascensius' edition, Paris, 1513, or in the later poems published at Lyons in 1516 . 
landabile carmen

omnem operam totumque caput, Silvane, requirit,

and Ecl. v, 90-91,

pannosos, macie affectos, farragine pastos

Aoniae fuginnt Musae, contemnit Apollo.

Ecl. vil, 27 is quoted in Abraham Fraunce's Latin comedy Victoria (c. 1580), 156,

nam Paris Iliaca tria numina vidit in Ida;

and the same play $(450,1913)$ repeats the "vult, non vult" of $E c l$. Iv, 123, and the "ludit Amor sensus" of Ecl. 1, 48. Another Cambridge play, Pedantius, 37, borrows the phrase " humeros vibrare natesque," from $E \mathrm{cl}$. Iv, 230 ; and a third, entitled Fucus, 11, 2, 32, repeats the "semel insanivimus omnes " of Ecl. 1, 118..$^{\mathrm{s}}$

In Robert Greene's Orpharion (ed. Grosart, xiI, 22) we have an unusual version of the story of Orpheus and Eurydice :

False harted wife to him that loned thee well,

To leaue thy loue and choose the Prince of hell,

and, again,

She slipt aside, backe to her latest loue.

His authority for this bit of mythology was probably Mantuan, Ecl. Iv, 178-179:

potuit, si non male sana fuisset,

Eurydice revehi per quas descenderat umbras.

In 1595 we have three "pastorall eglogues" by Francis Sabie, entitled Pan's Pipe. The first of these is practically

so See the recent editions of these three plays by G. C. Moore Smith: Pedantius and Victoria in Bang's Materialien sur $K$ unde des alteren Englischen Dramas, viII (1905) and XIV (1906), Fucws, at the Cambridge University Press. See, also, my note on Ecl. 1, 62. 
a cento made up from the first four eclogues of Mantuan." And in the third, Damon's "dittie" of the "stately progeny of heardsmen" is a paraphrase of Ecl. vII, 9-39.8.

In Milton's Lycidas, 128-129,

Besides what the grim wolf with privy paw Daily devours apace, and nothing said,

there seems to be an echo of Ecl. Ix, 141-147,

mille lupi, totidem vulpes in vallibus istis

lustra tenent,

. . factum vicinia ridet

nec scelus exhorret nec talibus obviat ausis;

and the abrupt close of the poem,

To-morrow to fresh woods and pastures new,

reminds one of Mantuan's closing line, Ix, 232,

Candide, coge pecus melioraque pascua quaere.

On Paradise Lost, vi, 871, "Nine days they fell," the commentators might perhaps quote $E c l$. II, 112-114,

\section{immo Satanum}

pessimus ex :llis quos noctibus atque diebus

ter tribus in terras fama est ex aethere lapsos-

as well as the description of the fall of the Titans in Hesiod.

The influence of Mantuan's Eclogues in sixteenth-century Germany would be an interesting subject, but that must be left to some one who has access to the necessary books. Some traces of it may be found in the Latin eclogues of Eobanus Hessus and Euricius Cordus.

Eobanus could claim to be a pioneer in the German field : "primi Latias in Teutona pascua Musas | ducimus," Idyl

67 See Modern Philology, viI (1910), 433-464, where Sabie's three Eglogues are reprinted, with some notes on his sources, by $\mathrm{J}$. W. Bright and W. P. Mustard.

B $\mathrm{K}$. Windscheid, Die englische Hirtendichtung von 1579-1625. Halle, I895, p. 4r. 
vili, 2-3.60 In his third Idyl (quoted above, p. 33) his shepherds discuss the respective merits of Virgil and Mantuan; and in his Adnotationes on the Bucolics and Georgics of Virgil he pays some attention to the later bucolic writers -among them "Petrarca, Pontanus, Baptista (Mantuanus)." "o The beginning of his fifth $I d y l$,

Montibus his mecum quondam, Philereme, solebas pascere, et alternis nostras concentibus aures mulcere, etc.,

reminds one of the beginning of Mantuan's fifth; and the close of his tenth,

tempestas oritur, pastu discedere tempus,

is like the close of Mantuan's second or third. Idyl 1,72 , "iam lectas omnis grex ruminat herbas," and Id. v1, 19,

et pecus ilicea dum ruminat omne sub umbra,

may be compared with Mant. 1, 1-2; Id. vIt, 135,

quisquis amat iacet, et presso fert vincula collo,

with Mant. I, 114-116; Id. XI, 68, " non tibi cum puero certandum impubere," etc., with Mant. $\mathrm{x}, 124$; Id. XI, 73-74,

est aliquid magno barbam attrectare prophetae; dicere sed volui (lapsa est mihi lingua) 'poetae,'

with Mant. x, 126-127. The "ventrosus bufo" of $I d, \mathrm{v}$, 55 , the " multiforem buxum" of $I d$. XI, 18, the " impatienter amantis " of $I d$. vII, 146, and the "somnollenti" of $I d$. XII, 6 , may be compared with Mant. X, 140; I, 163; vil, 65; III, 59.

80 Frankfort ed., 1564, p. 44.

-0 C. Krause, Helius Eobanus Hessus, Gotha, 1879, 11, 26. In an unfortunate footnote, Krause explains that the Fontanus referred to is "Petrus Pontanus (aus Brügge)," and thn! "Baptista Mantuanus" means "Joh. Baptista Fiera." 
In Euricius Cordus ${ }^{\circ 1}$ the imitation is still closer. The complimentary reference to Mantuan in his second Eclogue has been quoted above, p. 47. The historic dignity of the shepherd's calling, Ecl. III, is set forth as in Mantuan's seventh, $23 \mathrm{ff}$; and the contrast between the shepherd's lot and that of the farmer, in the middle of Ecl. IV, reminds one of the beginning of Mantuan's sixth. Compare, further, Ecl. 1, 36, for the intransitive "secundat," with Mant. v, 29; Ecl. II, 82, "luxati ... cultri," with Mant. v, 140 ; Ecl. II, 91, " nuda rigent genua," etc., with Mant. v, 23 ; Ecl. 11, 118,

pollicitos plures vidi, qui multa dedissent nullos,

with Mant. v, 105-106; Ecl. III, 34,

dum satur in gelidis grex pabula ruminat umbris,

with Mant. 1, 1-2; Ecl. III, 115,

sum puer, at memini quo magnum tempore munus

esse putabatur, si textam flore corollam

quis daret, etc.,

with Mant. III, 85-86; Ecl. III, 148,

inter tot juvenes quot festa luce sub ulmum conveniunt, ducuntque leves do more choreas,

with Mant. II, 63-65; Ecl. IV, 33,

mon sapies, risi torva pedum tibi cornua frangat,

with Mant. Iv, 91 ; Ecl. Iv, 48,

in grandique mihi legisse volumine dixit,

with Mant. vII, 155 ; Ecl. Iv, 64 (and v, 26), " quando vacat," with Mant. I, 9 ; $E c l$. Iv, 69, "desidiosa sumus pastores

-1 He, too, has been called a pioneer: "fu lodato, d vero, par le ecloghe, ma codesti componimenti, ch' egli introduce per la prima volta in Germania, - imita da G. B. Mantovano, gid per lui cadono in vuota pastorelleria," G. Manacorda, Della poesia latina in Germania durante il Renascimento, Rome, 1906, p. 280. 
turba," with Mant. VI, 19-20; Ecl. vI, 68, "qui nostra piacula solvunt," with Mant. vill, $162 ; E c l$. v1, 142,.

interea in pluvia pastor sitit, esurit aura,

with Mant. v, $12 ; E c l$. vil, 32,

versaque dormit humus, missum requiescit aratrum,

with Mant. vi, 2-3; Ecl. vil, 71, "grata laborantum requies," with Mant. vill, $150 ;$ Ecl. vill, 64-65,

succede sub ulmum,

dum redeo; mihi quid post saepta parumper agendum eat.

with Mant. Iv, 87-88; Ecl. vill, 102, "inscius et nihil hoc ratus," with Mant. Iv, 54-55 ; Ecl. vill, 109 (and IX, 65), "cariceam casulam," with Mant. IX, 18; Ecl. IX, 98,

me mea, te tua spes et opinio stulta fefellit,

with Mant. 1x, $192 ; E c l . x, 6$,

sed melior lento praestat vigilantia somno.

with Mant. I, 5 ; Ecl. x, 22 ,

utile servitium fuit illius atque fidele, donec, etc.,

with Mant. Iv, 22 ; Ecl. X, 28,

et nentes inter medius sub nocte puellas,

with Mant. v, $85 ; E c l . x, 123$,

- quoties patriae moesti reminiscimur orae,

with Mant. IX, 90.02

The famous diatribe against women, $E c l$. IV, 110 ff., has a rather close parallel in one of the Dialogues of Ravisius

22 These passages of Euricius Cordus are quoted from the "wcunda aeditio," Leipsic, 1518. 
Textor, Troia, Salomon, Samson.08 And it is very clearly echoed in Luigi Pasqualigo's comedy, Il Fedele, III, 7. Compare with lines $124 \mathrm{ff}$.,

mobilis, inconstans, vaga, garrula, vana, bilinguis, imperiosa, minax, indignabunda, cruenta, etc.,

Fortunio's speech:

Non dubbio, perche esse sono per nntura superbe, unne, inconstanti, leggieri, maligne, crudeli, rapaci, empio, inuidlose, incredalo, bugiarde, ambitiose, piene di fraude, disleall, ingrate, impetuose, audaci, \& senza freno, facilissime d dar ricetto d l' odio \& all' ira, 1 placnrsi durissime, portnno ouunque uanno ribellione o lite, elle sono unghe di dir male, d' necender odio trì gli nmici, di seminar infamia sopra $i$ buoni, sono pronte d riprender gli errori altrul, \& negligenti à conoscer i proprij vitij, sempre simulano, sempre fingono, tramano inganni, \& cercano di condur gli huomini alla morte, all' insidie che tendono, hanno cosi pronti $i$ gesti $e$ il uiso, nel quale $a$ suo piacere possono dimostrar allegrezza, dolore, tema, \& speranza, \& molti altri affetti, che alcuno non può fuggire da loro, \& quinci \& non altronde auengono tutti i nostri mali. ${ }^{84}$

But there must be many such echoes in the literature of Germany and France and Italy. One poem which will at least serve to illustrate the fourth Ecloguc is Tasso's Aminta. The chorus at the close of the first act,

\author{
Ma sol perchd quel vano \\ Nome senza soggetto, \\ Quell' idolo d' errori, idol d' inganno; \\ Quel che dal volgo insano \\ Onor poscia fu detto \\ (Che di nostra natura 'l feo tiranno), \\ Non mischiava il suo affanno
}

18 "Apud Iacobum Stoer," 1609, pp. 192-202. A part of the dialogue is quoted by $\mathrm{J}$. Vodoz, Le Théatre Latin de Ravisius Textor, Winterthur, 1898, pp. 149-151.

ot Venice ed., 1579. Pasqualigo's comedy is paraphrased in Larivey's Le Fidelle; for this particular passage, see Ancien Theatre francois, vI, 397. It is adapted also in Abraham Fraunce's Latin comedy Vicloria; but Fraunce's play omits all this diatribe. So does the English adaptation by Anthony Munday (recently printed by F. Flügge, Archiv für das Studium der neueren Sprachen und Literaturen, cxxili, 48-80). 
Fra le liete dulcezze

Doll' amoroso gregge, otc., 10

may be compared with Ecl. II, 161-166,

qui non communicat usum

coniugis invidus est; livorem excusat honestas introducta usu longi livoris iniquo.

nam dum quisque sibi retinet sua gaudia, nec valt

publica, communis mos ac longaevus honestas

factus, et hunc morem fecit dementia legem;

and the passage in $I 1,2$,

Or, non sni tu com' d fatta la donna?

Fugge, - fuggendo vuol ch' altri la giunga;

Niega, e negando vuol ch' altri si toglia;

Pugna, e pugnando vuol ch' altri la vinca,

with Ecl. IV, 216-218,

currit, ut in latebras ludens perducat amantem, vult dare, sed cupiens simplex et honesta videri denegat et pugnat, sed vult super omnia vinci.

And with Ecl. II, 25,

commoditas omnis sua fert incommoda secum,

we may compare Guazzo's Civil Conversatione, Bk. i, "anzi si ha da ricordare di quella sentenza: 'Ogni agio porta seco il suo disagio." " The sentiment was doubtless a commonplace, but Mantuan may have helped to make it so.

\section{MANTUAN'S SOURCES}

Mantuan's chief model in pastoral was Virgil, and the influence of Virgil may be traced on almost every page. But. there are many echoes of other Roman poets or -especially

O5 This chorus is literally translated in Samuel Daniel's 'pastorall' on the Golden Age.

oe Venice ed., 1590, p. 12.

or Some of these are pointed out in the Notes. For Ovid, see notes on Ecl. 11, 85; III, 171; IV, 132, 201; viI, 147; for Tibullus, 
Ovid and Juvenal-and there are half a dozen passages in which he imitates the Latin eclogues of Petrarch ai and Boccaccio. And he owes something to the Ecclesiastical Writers-especially Prudentius ${ }^{\circ 0}$-and to the language of the Latin Bible. ${ }^{70}$

His style was formed on classical models, and he doubtless meant his Eclogues to be classical throughout. But they contain a fair number of irregularities-in syntax, in vocabulary, and in metre. Some of these are due to his familiarity with Ecclesiastical Latin, while others can be tound only in the Latin of the Middle Ages. Some of them are merely mistakes of a youthful author which remained uncorrected even when the poems were revised.

notes on $E c l$. III, 103-8; vill, 98-101; 1x, 107; for Juvenal, notes on Ecl. v, especially lines 90-91, 104; for Calpurnius, notes on Ecl. II, 1; vi, 157; $1 \mathrm{x}, 107 ; \mathrm{Ix}, 133$.

${ }^{68}$ See notes on $E c l .1,12-13$; 11, 17-27, 32-33; v, 46, 136.

${ }^{69}$ See notes on Ecl. IV, 212 ; vil, 162 ; Ix, 126-7. In an apology for poetry prefixed to his first Parthenice, Mantuan cites several of the Ecclesiastical Writers: Prudentius, Paulinus of Nola, Ambrosius, Beda, and Juvencus. And of these his favorite would seem to be Paulinus: "quid de Paulino Nolanae urbis episcopo Hieronymo contemporaneo et familiari? nonne pulcherrima quae adhuc extant, et semper extabunt, excudit poemata? cum adhuc adolescentulus essem et a studiis ecclesiasticis more illius aetatis abhorrerem, forte in ea poemata incidi, et carminis suavitate delectatus animum ad res divinas paulatim appuli, et ex illo tempore sacrarum litterarum studiosior fui."

${ }^{70}$ See notes on $E c l .11,138$; III, 188; v, 129; viII, 85-86; viII, 222. Another possible "source" is mentioned by Ascensius, on $E \mathrm{cl}$. v, ror, where he guesses that "Umber" means Niccolò Perotti, Bishop of Siponto: "quem nescio an Sipontinum dicam, a quo plurima sumpsisse videtur." This refers to Perotti's great commentary on some of the epigrams of Martial, entitled Cornucopiae: seu Commentarii Linguae Latinae. It was printed as early as 1489 . It was freely nsed by Ascensius in his commentary on the Eclogues, and it was doubtless well known to Mantuan himself. Indeed, his brother Tolomeo reports of him: "damnabatque episcopum Sipontinum quod, cum esset primi ordinis in ecclesia, tantopere laboravit in enarratione Martialis poetae gentilis epigrammatarii" (Apologia, Lyons ed., 1516, fol. $\mathrm{Gg}$, iii). 


\section{SYNTAX}

One interesting bit of syntax is the use of the simple subjunctive after a verb of thinking: credo... concitet et ...tollat, $1,50-51$; puto sidera tangant, vili, 44 . Another is the use of putare, credere, or aestimare, with a simple infinitive, apparently on the analogy of verbs of "hoping" or "expecting": grande aes conflare putabam, III, 75; qui flectere divos | creditis, III, 141-2; et vertere in aurum | acstimat, vı, 133-4. Facerc is used with the infinitive, in the sense of "to cause to": $\mathrm{v}, 58 ; 1 \mathrm{x}, 221$. Intinderi" (= animum intendere) is used with the dative, 1,$106 ; 11,49$; subintrare, with the accusative, 1,176 ; $1 \mathrm{~V}, 90$; sicundare, with the dative, $v, 29$; obviare, with the dative, $1 x, 147$. The use of mood and tense with dum is largely a matter of inetrical convenience : cp. 1, 25, dum mens erat ; vil, 147-8, dum ... obstaret...dum tepet ac timide insanit; vill, 19, dum... castraret; vIII, 120, dum ... perlegerem; Ix, 55, licuit dum; x, 96-7, dum viximus una, |dum ... fuit.

\section{METRE}

Some of the metrical irregularities have been revised out by editors. In the Mantua edition of 1498 we have quottídie, I, 120; ómissa, II, 5 (ömisit, X, 69) ; sciderat, II, 46; somnōlentum, III, 59 ; Sătänum, II, 112 ; muliēribus, Iv, 70 (muliēre, Iv, 206 and vi, 57, muliērum, Iv, 245); găneae, Iv, 129 (gănea, v, 151) ; sübicit, Iv, 156; pülicum, viII, 10 ; cìmicum, vill, 10; anginoso, vill, 145; săbüco, 1X, 96; căcăbos, Ix, 177 ; postěă, vili, 47 , and perhaps vil, $25^{71}$ There are three spondaic verses, v, 120, v, 129, vill, 213. There are five such cadences as térĕbinthĩ: 1, 31 ; viI, 133; vIII, 10 ; IX, 69 ; IX, 168.

\section{VOCABULARY}

In the vocabulary, there a number of departures from classical usage. Modo is used half a dozen times in the sense of nunc, I, 4; II, 151, etc.; parum means "a little

71 For anginoso and săbūco, he could cite the authority of Serenus Sammonicus; căcăbos may be found in the Macaronea of his younger contemporary, Teofilo Folengo; for ganeae, he had the authority of Prudentius; for sciderat, that of Servius. 
while," Ix, 20 and 39. Inquis is used for memoras, or dicis, v, 67 ; vIII, 67 ; X, 53; ullus for aliquis, vI, 251. At 1, 103 we have de sub, "from under," and at Ix, 122, a longe, "from afar." Semel means aliquando, 1, 118; ipsis is used for eis, II, 147, VIII, 112, 173 ; ista refers to what follows, III, 122 ; vIII, 95. Accubitu means "bed," vI, 52 ; tegetis means tecti, or tugurii, Ix, 51 ; tabellam is the "lid" or "cover" of a jug, Ix, 39. Polenta is used as a neuter singular, vi, 5; vIII, 23. There are some unusual words: claviculo, II, 100; influxibus, IX, 149; rulla, I, 142; runca, IV, 49 ; variantia, X, 91 ; callosa, vIII, 25 ; cariceae, IX, 18; fluvios, VIII, 65 ; hernica, IV, 118 ; impetuosa, IV, 134 ; saltidico, I, 171 ; situosus, vilI, 65 ; squarrosa, v, 72 ; suaviloquo, IV, 9 ; ventrosus, X, 140 ; appropiare, IX, 119 ; fetant, II, 30 ; incalluit, III, 25 ; infortunarit, III, 167 ; obtenebrescere, vI, 239 ; obviat, Ix, 147 ; opulescunt, IX, 168 ; praesentas, IV, 90. Catus, I, 59, is the animal; philomena is the bird, I, 27 ; Ir, 46, etc.; vulpes, vi, 26, means pelles vulpinas. There are Greek words, like artocopi, vI, 100 ; artocreas, vIII, 23 ; brucho, viIr, 132 ; cercopithecos, vI, 144 ; eremum, X, 175 ; genethliacos, v, 39 ; gynaecei, vIII, 192 ; lampyrides, I, 155; melotas. vI, 27; ogdoas, vII, 181; onocrotalus, vIII, 59 ; orexis, I, 17 ; rhomphaea, IV, 211 ; zelotypo, vi, 71. Pietas = "alms," vi, 157; luxuria= "lust," IV, 161; substantia = "wealth," III, 8; deitas = divinitas, vII, 33 ; extimare $=$ aestimare, 111,16 ; intendere $=$ animum intendere, I, 106 ; 11, 49. 


\section{BAPTISTAE MANTUANI ADULESCENTIA}




\section{F. BAPTISTA MANTUANUS CARMELITA PARIDI CERESARIO D.S.}

Audi, o Pari, aenigma perplexum quod Oedipodes ipse non solveret. ego quinquagenarius et iam canescens adulescentiam meam repperi, et habeo adulescentiam simul et senectam. sed ne longa ambage te teneam, nodum hunc dissolvo. anno praeterito, cum Florentia rediens Bononiam pervenissem, intellexi apud quendam litterarium virum esse quendam libellum meum quem olim ante religionem, dum in gymnasio Paduano philosophari inciperem, ludens excuderam et ab illa aetate Adulescentiam vocaveram. carmen est bucolicum in octo eclogas divisum, quod iam diu tamquam abortivum putabam abolitum. ubi id rescivi, Saturnina fame repente sum percitus, et cogitavi quonam pacto possem proli meae inferre perniciem. iuvantibus ergo amicis libellum meum vindicavi, ut perderem quem suspicabar erratis non posse non scatere. at ubi intellexi et alia quaedam exemplaria superesse, visum est praestare hoc quod vindicaram emendare emendatumque edere, ut eius editione cetera quae continent multa nimis iuvenilia deleantur. hoc igitur sic castigatum duabus aliis eclogis quas in religione lusi in calce subiunctis tibi, o Pari, iuvenis antiquae nobilitatis et studiorum ac omnium bonarum artium amantissime nostraeque urbis decus egregium, libentissime dono, ut, quando tetricis illis philosophiae ac theologiae lucubrationibus quibus assidue vacas fatigatus fueris, habeas iucundulam hanc lectiunculam qua tamquam ludo quodam blandulo sed liberali lassum legendo reparetur ingeniun. omnes autem penes quos immatura illa sunt exemplaria quae dixi rogatos volo ut, si quid umquam fuit eis dulce meum, confestim exurant nec ullo pacto superesse permittant. accipe ergo, Pari suavissime, libellum et auctorem, et ambobus tamquam rebus tuis tuo deinceps utaris arbitrio. vale. Kalendis Septembris, mcccclxxxxvir.

62 


\section{ECLOGA I, FAUSTUS,}

\section{DE HONESTO AMORE ET FELICI RIUS EXITU.}

\section{FORTUNATUS. FAUSTUS.}

For. Fauste, precor, gelida quando pecus omne sub umbra ruminat, antiquos paulum recitemus amores, ne, si forte sopor nos occupet, ulla ferarum quae modo per segetes tacite insidiantur adultas saeviat in pecudes; melior vigilantia somno.

Fau. Hic locus, haec eadem sub qua requîescimus arbor scit quibus ingemui curis, quibus ignibus arsi ante duos vel (ni memini male) quattuor annos; . sed tibi, quando vacat, quando est iucunda relatu, historiam prima-repetens -al, origine pandam.

Hic ego, dum sequerer primis armenta sub annis, veste solo strata sedi iacuique supinus cum gemitu et lacrimis mea tristia fata revolvens. nulla quies mihi dulcis erat, nullus labor; aegro pectore sensus iners, et mens torpore sepulta ut stomachus languentis erat quem nulla ciborum blandimenta movent, quem nulla invitat orexis. carminis occiderat studium, iam nulla sonahat fistula disparibus calamis; odiosus et arcus, funda odiosa, canes odiosi, odiosa volucrum praeda, nucum calyces cultro enucleare molestum; texere fiscellam iunco vel vimine, piscem fallere, scrutari nidos, certare palaestra, sortiri digitis res iniucunda, voluptas magna prius, tanti dum mens erat inscia morbi. colligere agrestes uvas et fraga perosus maerebam ut pastu rediens philomena cibumque ore ferens natis, vacuo sua pignora nido cum sublata videt : rostro cadit esca remisso, cor stupet et contra nidos super arboris altae fronde sedet plorans infelices hymenaeos; seu veluti amisso partu formosa iuvenca 
quae, postquam latos altis mugitibus agros complevit, residens pallenti sola sub umbra gramina non carpit nec fluminis attrahit undam.

Sed quid circuitu pario tibi taedia longo, dum sequor ambages et verba et tempora perdo? summa haec: vitales auras invitus agebam. quod si forte volens cognoscere singula dicas, 'Fauste, quis in syrtes Auster te impegerat istas?' me mea (verum etenim tibi, Fortunate, fatebor) me mea Galla suo sic circumvenerat ore ut captam pedicis circumdat aranea muscam. namque erat ore rubens et pleno turgida vultu et, quamvis oculo paene esset inutilis uno, cum tamen illius faciem mirabar et annos, dicebam Triviae formam nihil esse Dianae.

For. Ludit Amor sensus, oculos praestringit et aufert libertatem animi et mira nos fascinat arte; credo aliquis daemon subiens praecordia flammam concitet et raptam tollat de cardine mentem. nec deus (ut perhibent) Amor est, sed amaror et error.

Fau. Adde quod optatis nec spes erat ulla potiri, quamvis illa meo miserata faveret amori monstraretque suos oculis ac nutibus ignes. nam, quocumque isset, semper comes aspera: semper nupta sequebatur soror et durissima mater.

sirque repugnabant votis contraria vota non secus ac muri catus: ille invadere pernam nititur, hic rimas oculis observat acutis.

For. Qui satur est pleno laudat ieiunia ventre, et quem nulla premit sitis est sitientibus asper.

Fau. Tempus erat curva segetes incidere falce et late albebant flaventibus hordea culmis. affuit (ut mos est) natis comitata duabus collectura parens quae praeterit hordea messor, ignorabat enim vel dissimulabat amorem; dissimulasse puto, quoniam data munera natae noverat, exiguum leporem geminasque palumbes.

For. Pauperies inimica bonis est-moribus; omne labitur in vitium, culpae scelerumque ministra est.

Fau. Farra legens ibat mea per vestigia virgo nuda pedem, discincta sinum, spoliata lacertos, 
ut decet aestatem quae solibus ardet iniquis, tecta caput fronde intorta, quia sole perusta fusca fit et voto facies non servit amantum. iam tergo vicina meo laterique propinqua sponte mea delapsa manu frumenta legebat. nec celare suas nec vincere femina curas nec differre potest; tantum levitatis in illa est.

For. Quisquis amat levis est, nec femina sola sed ipsi quos sapere et praestare aliis mortalibus aiunt, quos operit latus fulgenti murice clavus, quos vidi elatos regali incedere passu.

tu quoque sic affectus eras dementior illa forsitan et levior. virgo data farra legebat, at tu farra dabas; dic, quae dementia maior $\bar{?}$ perge; opus est verbis aliquando arcere soporem.

Fau. Continuo aspiciens aegre tulit aspera mater et clamans 'quo', dixit, ' abis? cur deseris agmen? Galla, veni, namque hic alnos prope mitior umbra, hic tremulas inter frondes immurmurat aura.' o invisa meis vox auribus! 'ite', precabar, 'ite, malam venti celeres dispergite vocem.' si quis pastor oves ad pinguia pascua ducat et vetet adductas praesens decerpere gramen, vel si iam pastas potum compellat ad amnem et sitibundo ori salientem deneget undam, nonne importunus, naturae inimicus et excors? illa mihi vox visa Iovis violentior ira cum tonat et pluvius terris irascitur aer. non potui (et volui) frontem non flectere; virgo demissi in cilium de sub velaminis ora me aspiciens motis blande subrisit ocellis. id cernens iterum natam vocat improba mater; Galla operi magis intendens audire recusat. ut pede, sic animo sequitur. tum providus ipse (namque dolos inspirat Amor fraudesque ministrat) nunc cantu, nunc sollicitans clamore metentes velamenta dabam sceleri, quo credere possent et soror et mater non audivisse puellam. falce repellebam sentes, ne crura sequentis levia, ne teneras ausint offendere plantas.

For. Quisquis amat servit: sequitur captivus amantem, 
fert domitā cervice iugum, fert verbera tergo dulcia, fert stimulos, trahit et bovis instar aratrum.

Fau. Tu quoque, ut hinc video, pon es ignarus amorum.

For. Id commune malum, semel insanivimus omnes.

Fau. Hoc animi tam triste bonum, tam dulce venenum, cottidie crudele magis crescebat in horas, 120 ut calor, in nonam dum lux attollitur horam. pallebam attonito similis, lymphaticus, amens, immemor, insomnis. nec erat res ardua morbi nosse genus; frons est animi mutabilis index. ut pater advertit, mitem se praebuit ultra consuetum, quod et ipse suos expertus amorum sciret onus, blandoque loquens humaniter ore 'dic', inquit, 'dic, Fauste, quid hoc quod pectore volvis? infelix puer, haec facies testatur amorem. dic mihi ; ne pudeat curas aperire parenti.'

For. Sit licet in natos facies austera parentum, aequa tamen semper mens est, et amica voluntas.

Fau. Ut facilem pater affectum prae se tulit, ultro rem confessus opem petii. promisit; et ante quam brumale gelu Borealihus arva pruinis spargeret, agnati unanimes cum patre puellam despondere mihi. nec adhuc sine testibus alli congredichar; eram medio sitibundus in amne Tantalus, o quotiens misso cum bobus aratro, ut vacuis aliquando esset sola aedibus, ilam! omnia causabar, stivam, dentale iugumque, lora iugi, rullam; deerant quaecumque, petelsam e soceri lare. sola tamen deerat mihi virgo. non deeram mihi; piscator, venator et auceps factus eram, et sollers studia intermissa resumpsi. quidquid erat praedae, quidquid fortuna tulisset, ad soceros ibat; gener officiosus habebar. nocte semel media subeuntem limina furtim (sic etenim pactus fueram cum virgine) furem esse rati invasēre canes; ego protinus altam transiliens saepem vix ora latrantia fugi.

$\mathrm{H}$ is tandem studiis hiemem transegimus illam. ver rediit. iam silva viret, iam vinea frondet, iam spicata Ceres, iam cogitat hordea messor. splendidulis iarn nocte volant lampyrides alis ; 
ecce dies genialis adest, mihi ducitur uxor. sed quid opus multis? nox exspectata duobus venit, et in portum vento ratis acta secundo est. tum bove mactato gemina convivia luce sub patula instructis celebravimus arbore mensis. affuit Oenophilus multoque solutus Iaccho tempestiva dedit toti spectacula vico. et cum multifori Tonius cui tibia buxo tandem post epulas et pocula multicolorem ventriculum sumpsit, buccasque inflare rubentes incipiens oculos aperit ciliisque levatis multotiensque altis flatu a pulmonibus hausto utrem implet, cubito vocem dat tibia presso. nunc huc, nunc illuc digito saliente vocavit pinguibus a mensis iuvenes ad compita cantu saltidico dulcique diem certamine clausit. et iam tres hiemes abiere et proximat aestas quarta : dies rapidis, si qua est bona, praeterit horis. si qua placent, abeunt; inimica tenacius haerent. For. Fauste, viden? vicina pecus vineta subintrat; iam (ne forte gravi multa taxemur) eundum est. 


\title{
ECLOGA II, FORTUNATUS,
}

\author{
DE AMORIS INSANIA.
}

FAUSTUS. FORTUNATUS.

Fau. Cur tam serus ades? quid te (iam septima lux est) detinuit? gregibusne nocent haec pascua vestris?

For. Fauste, Padus nostros qui praeterlabitur agros creverat et tumidis ripas aequaverat undis; nos, cura gregis omissa, privata coegit publicaque utilitas ripam munire diurnis nocturnisque operis fluviumque arcere furentem.

Fau. Fert Padus exundans mala saepius omina: noster 'Tityrus est auctor, qui pascua dixit et arva.

For. Forsitan id verum, quando extra tempora et ultra 10 mensuram atque modum subito concreverit aestu. nunc autem id poscit tempus, nam liquitur altis nix hiberna iugis, implent cava flumina montes.

Fau. Se exonerant fluviosque onerant. sic flumina rursum se exonerant pelagusque onerant ; hominum quoque mos est quae nos cumque premunt alieno imponere tergo.

For. Sed iam contractum revocat suus alveus amnem.

Fau. Decrescente Pado (dictu mirabile) noster,

Fortunate, lacus maioribus aestuat undis. urbs natat, obscurae fiunt cellaria fossae.

lintre cados adeunt; labens ad vina minister ridet, et ex imis fertur gravis obba lacunis. multa, licet nati fucrint melioribus horis, multa et magna ferunt aliquando incommoda cives.

For. Commoditas omnis sua fert incommoda secum, et sorti appendix est illaetabilis omni.

Fau. Hactenus Eridanus; nostros repetamus amores, quandoquidem nunc alma Venus movet omnia, caelum luce tepet nitida, tellus viret, arva volucres cantibus exhilarant vernis, nunc omnia fetant.

For. 'l'u tua lusisti, sed nos aliena sequamur. namque tihi noti referam pastoris nmores, ut docenm Veneris nihil osso potentius igne, 
Pauper et infesto sub sidere natus Amyntas sex vitulos totidemque pares aetate iuvencas armentique patrem ducens in pascua taurum venerat ad Coitum, nitidis ubi Mincius undis alluit herbosos fugiens perniciter agros.

arx nova propter aquas pinnatis ardua muris est Coitus, campo moles fundata palustri. hic igitur recubans vitrei prope fluminis undam, vitis ubi amplectens longis dumeta lacertis in vada curvata ripae supereminet umbra, piscibus insidias tendebat harundine et hamo. messis erat: solis rapidi violentia campos sciderat arentes, finem philomena canendi fecerat, et neque lux, passim morientibus herbis, pascere oves poterat neque nox umore cicadas. dumque incumbit aquis studioque intendit inani, taurus (ut auditum e.st) primum vexatus ab oestro, mox canibus, demum furaci a milite silvis abditus ex toto confestim evanuit agro.

Quod puer ut novit, tumulum conscendit et alta voce bovem clamans longo rura omnia visu prospicit. ut frustra niti se comperit, arcum corripit et pharetram sequiturque per invia taurum. illum per caulas et per stabula omnia quaerens per colles, Benace, tuos, per consita olivis iugera, per virides ficis et vitibus agros, venerat ad sublime iugum quod sulphuris arcem sustinet et longis aperit prospectibus illinc Benacum, hinc campos longe lateque patentes. lux ea sacra fuit Petro: frondente sub ulmo mixta erat ex omni pules post prandia vico ducebatque leves buxo resolnante choreas.

Fau. Rustica gens, nulla genus arte domabile, semper irrequietum animal, gaudet sudore. peracto mane sacro festa (quando omnibus otia) luce ipsa oti ac famis impatiens epulatur et implet ingluviem. audito properat tibicine ad ulmum; hic furit, hic saltu fertur bovis instar ad auras. quam rastris versare nefas et vomere terram calcihus oblyris et inerti mole fitignt aIC ferit, et tota Baccho facit orgin luce 
vociferans, ridens, saliens et pocula siccans.

For. Stulte, quid haec faris? solatia rustica damnas rusticus ipse? tuis malus es, tibi pessimus ipsi.

Fau. Dicta ioco fuerint; nostrum repetamus Amyntam.

For. Continuit gressum baculoque innixus acerno intermisit iter, donec mitesceret aestus.

ah puer infelix, aestus te maior in umbra corripiet. nudam videas ne in fonte Dianam, claude oculos, blandis neu des Sirenibus aurem. sors tua Narcisso similis: Narcissus in undis dum sedare sitim properat, sitit amplius; at tu exteriorem aestum fugiens intrinsecus ardes. quam melius fuerat (nisi te sic fata tulissent) ad reliquum rediisse pecus, servasse iuvencas, amissi bovis aequo animo dispendia ferre quam, dum conaris nil perdere, perdere te ipsum.

Fau. Sed post iacturam quis non sapit? utile non est consilium post facta, dari quod oportuit ante. consilium post facta, imber post tempora frugum.

For. Una puellares inter pulcherrima turmas virgo erat, alba comas, aliis procerior, annos nata quater quinos vel circiter, ore nitenti urbanis certare potens et vincere nymphis. aureolis radians guttis ad tempora limbus ibat, et ad pectus clausum velamen aëno claviculo; mediam fulgenti fibula ferro 100 stringit in angustum; nova candicat instita lapsu linea rugoso pediliusque allabitur imis. hanc puer ut vidit, periit flammasque tuendo hausit et in pectus caecos absorbuit ignes, ignes qui nec aquis perimi potuere nec umbris diminui neque graminibus magicisve susurris. oblitusque greges et damna domestica totus uritur et noctes in luctum expendit amaras.

Saepe gravescentem verbis compescere flammam nixus et insanum iuvenis cohibere furorem dicebam: 'miserande puer, quis te deus istas misit in ambages? sed non deus, immo Satanum pessimus ex illis quos noctibus atque diebus ter tribus in terras fama est ex aethere lapsos. dic, age, si nosti quemquam, reminiscere si quem 
videris hoc pacto ditescere, surgere in altum, dilatare domum, maioribus horrea acervis complere his studiis, extendere latius agros, multiplicare greges, acquirere pascua bobus. inter tot populos quot habet latissima tellus sunt qui nostra ferant mensis epulanda cruentis corpora et humanos absumant dentibus artus ; surit, inquam, quos tanta malis tot vexet Erinys; sed nullum est tam immane genus, tam barbara nusquam gens, quae femineos non exsecretur amores. hinc veniunt rixae, veniunt et iurgia et arma, saepe etiam dirae multo cum sanguine mortes; hinc quoque deletis eversae moenibus urbes. ipsae etiam leges rubrisque volumina loris clausa vetant scelus hoc et detestantur amores.'

Ut leges audivit, ad haec respondit Amyntas (civis enim fuerat puer et versatus in urbe) ' his monitis prudens et circumspectus haberi niteris et sensu tetricos anteire Catones. error hic, haec passim sapiens dementia regnat. ipse sibi blanditur homo sollersque putari vult animal; tamen incautus silbi multa tetendit retia et in foveam cecidit quam fecerat. ante liber erat; servile iugum sibi condidit ipse ; pondus id est legum (vidi ipse volumina) quas nec antiqui potuere patres, nec possumus ipsi, nec servare aetas poterit ventura nepotum. aspice quam stulta est hominum prudentia: caelum sperat et esse sibi sedem inter sidera credit; forsitan in volucrem moriens transibit et altum spiritus assumptis tranabit ad aethera pennis.'

'Tunc ego: 'quid latras? legum Deus auctor, et ipsis non parere sapit magnam nimis impietatem.'

Fau. Grandia de magnis haec sunt certamina rebus.

For. Quid fuerim reris? quamvis pannosus et asper 150 sim modo, tunc animo, tunc vi, tunc ore val bam, nec mihi sese alius poterat componere pastor.

Fau. Nunc quoque, si rectus vultu gradiare supino, alter eris Marius; raso ore videbere Carbo.

For. Talia respondit sic obiurgatus Amyntas:

' facto homini Deus invidit (concessa voluptas 
visa bonum nimis excellens) et vota repressit legibus inventis, ut equi ligat ora capistro, ne quocumque libet flectat vestigia, sessor. quae mea sit me cogit amor sententia fari, 160 liberaque ora facit: qui non communicat usum coniugis invidus est ; livorem excusat honestas introducta usu longi livoris iniquo. nam dum quisque sibi retinet sua gaudia, nec vult publica, communis mos ac longaevus honestas factus, et hunc morem fecit dementia legem. invida res amor est, res invidiosa voluptas.'

'Tunc ego non audens hominem contendere contra amplius insano rediens ab amante recessi.

Fau. Cernis ut hic malus affectus sic lumina mentis 170 claudat, in errores ut sponte feramur apertos?

For. Cernis ut a summo liventia nubila Baldo se agglomerent? oritur grando; ne forte vagantes tempestas deprendat oves, discedere tempus. 
ECLOGA III, AMYNTAS,

\section{DE INSANI AMORIS EXITU INFELICI.}

FAUSTUS. FORTUNATUS.

Fau. Illa hesterna ruens Baldi de vertice grando, Fortunate, fuit nobis innoxia (divis gratia nostrarum quibus est custodia frugum) sed, veluti ex illis veniens ait Harculus oris, Veronensem agrum, pecudes et ovilia sic est demolita, casas et pastoralia tecta sic evertit, ut agricolis spes nulla supersit. agricolis etenim pecus est substantia, et arva his subiecta malis; grandi thesaurus in arca civibus est quem nulla queat contundere grando, nulla pruina, gelu nullum, nullae aëris irae.

For. Nescio quis ventos tempestatesque gubernat; id scio (sed neque si scio sat scio, sed tamen ausim dicere-quid? vitane ideo multabor in ipsa?) numina si, ut perhibent, orbem moderantur ab alto, extimo nil duros hominum curare labores. aspice quo tenuem victum sudore paramus, quot mala pro grege, pro natis, pro coniuge pastor fert miser. infestis aestate caloribus ardet, frigoribus riget hibernis; dormimus ad imbrem cotibus in duris vel humi; contagia mille, mille premunt morbi pecudes, discrimina mille sollicitant, latro insidias intentat ovili atque lupus milesque lupo furacior omni. ut manus assiduo detrita incalluit usu, squaluit os, barba obriguit, cutis aruit zestu, una repentino rapit omnia turbine grando. hoc Superi faciunt quibus inclinamur ad aras et quibus offerimus faculas et cerea vota. nescio quae pietas et quae clementia tantis cladibus involvat pastores omnium egenos.

Fau. Fortunate, scelus nobis haec omnia nostrum ingerit; aetherei sententia Iudicis aequa est. 
For. Quod scelus? an fuimus Christi vitae insidiati?

Fau. Iurgia, furta, irae, Venus et mendacia, rixae.

For. Quid meruere boni? nec enim scelus obruit omnes, et tamen una omnes pariter pessumdat Erinys.

Fau. Heu nescis male de Superis sentire nefandum? his igitur quae scire nefas, nescire necesse est, posthabitis curas iterum repetamus Amyntae quas sumus experti, quas ignorare negatum est ; res vulgaris amor, studium commune iuventae.

For. Maeror et affectus alii de cardine mentem saepe levant; animo sermo venit aeger ab aegro.

Fau. Intellecta licet pro re, pro tempore fari (sic habitus Cosnas sapiens) incognita numquam.

For. Fauste, sapis; notos igitur repetamus amores. restat Amyntaeos postrema in fata furores ducere et in misero lacrimas impendere casu.

Praeteriens illac parvo post tempore rursum 50 insanire hominem video et miseratus amantem ' 0 ,' iterum dixi, ' mens inconsulta veneno ebria fatali. populo iam fabula factus non resipiscis adhuc, et adhuc in amore sepultus te ruis atque tuos, pecus atque mapalia, tecum ut quondam moriens rapuit secum omnia Samson. cum senio curvatus eris (si forte senectam fata tibi dederint) quis sustentabit inertem, somnolentum, inopem, cum iam defecerit omne robur et ingenium, sensusque recesserit omnis? haec tibi cuncta feret (nisi mors praevenerit) aetas. esto domi, vigila, observa, super omnia semper prospice quo tendas, et quo venisse dolendum est ire cave. discerne vias hominemque memento non ad delicias, non ad muliebria natum blandimenta levi tam perniciosa iuventae. ipse ego cui pecudes, cui lac, cui caseus, aegre vitam ago ; tanta agros omnes invasit egestas, tot duri rerum eventus, incommoda passim tanta, tot adversis totus convolvitur orbis. accipe rem non auditam, non tempore factam praeterito, sed quam lux haec mihi protulit ipsi. ut mos, autumno pecudes crescente totondi. mane foro exposui lanae venalia pondo 
sexaginta hodie, grande aes conflare putabam; vix vitam gregis eduxi, vix pabula possum mercari hibernis nivibus; quo cetera pacto sit victura domus nondum mihi constat, Amynta. quisquis amat dominae munuscula mittat oportet; tu vero cui vix tectum fortuna reliquit sub quo luce habitat, sub quo pernoctat egestas, quid poteris cupidae gratum donare puellae? mittere mala decem satis esse solebat amanti, purpurei flores et raptus ab arbore nidus, gramen odoriferum, memini quo tempore magnae credebantur opes; ventum est a gramine ad aurum. regia res amor est hac tempestate; recessit mos vetus et quaedam mala lex inolevit amandi.'

Talia suadenti torvo mihi rettulit ore: ' si cupis optatam mihi, Fortunate, salutem, da quod amo; nostro haec una est medicina dolori. cetera quae memoras mihi sunt tormenta. revelli ex animo furor iste nequit; mea pectora imago virginis obsedit, mecum est, mecum itque reditque, excubat et dormit mecum ; caput, ossa, medullas, cor complexa potest cum sola excedere vita. ac veluti quotiens aliena ex arbore secto surculus inseritur trunco, natura duorum iungitur et mixto coalescit corpore virga, sic dominae dilecta mihi se immersit imago et fecit duo corda unum, duo traxit in unum pectora ; sensus inest nobis et spiritus idem. o me felicem, si, cum mea fata vocabunt, in gremio dulcique sinu niveisque lacertis saltem anima caput hoc languens abeunte iaceret; illa sua nobis morientia lumina dextra clauderet et tristi fleret mea funera voce. sive ad felices vadam post funera campos, seu ferar ardentem rapidi Phlegethontis ad undam, nec sine te felix ero, nec tecum miser umquam.

- Dryades florumque deae Nymphaeque decentes,

o nemurum Silvane pater, servate (precamur) collibus in vestris gelidisque in vallibus omne silvarum rurisque decus; circumdate saltus saepibus et prohibete pecus, ne floribus obsit; 
ista (precor) dominae servate in funera nostrae. tunc omnis spargatur humus; redolentia serta texite, quae circa tumulum supraque iacentem componantur heram. tristes ad busta puellae Pierides aderunt et lamentabile carmen

ore canent madido signataque verba relinquent ista sepulturae relegenda nepotibus olim: HIC TEGITUR VIRGO CUI NIL QUIN DIVA VOCARI DEBUERIT DEERAT, NISI DURA FUISSET AMANTI. o virgo, si te tantus consumeret ardor, per centum Scyllas ad te, per mille Charybdes, tranarem laturus opem; tu saevior Hydra me fugis. at culpae nihil est in virgine, nam me nescit adhuc; si sciret enim, succurreret ultro, nec puto sub miti tam ferrea pectora vultu. signa tamen vultus fallacia; sub cute molli mens fera, sub blanda sunt corda immania fronte. alloquar et faciam nostros intellegat ignes. si tamen illa meos vultus averterit, ibunt in lacrimas oculi, triste in suspiria pectus. oderit illa licet semper fugiatque sequentem, ista tamen, quocumque ferar, me cura sequetur. ite procul medicae, non sum sanabilis, artes, ite procul magico qui (quod nec credere dignum est) earmine pallentes animas revocatis ab Orco, ite procul vanis precibus qui flectere divos creditis; adversum est et inexorabile caelum. me rapit impatiens furor et iuvat ire per altos solivagum montes, per lustra ignota ferarum.'

Talia iactantem verbis conabar amicis flectere, sed vulnus nihil insanabile curat. illum per campos nox intempesta silentes, illum exorta dies inter dumcta videbat insomnem semper, raro silvestria poma carpentem et potu contentum simplicis undae. post longos gemitus exhaustaque lumina fletu assiduo, post lamenta et convulsa frequenti pectora singultu, moriens finivit amores. exanimum corpus tumuli sine honore relictum nocturnae absumpsere ferae volucresque diurnae.

Fau. Heu funesta lues, fatalis machina passim 
corda venenatis penetrans humana sagittis, aequiperans hominem pecudi. quae pocula Circe, quae peiora umquam potuit dare philtra Calypso? quae Styx, quis Phlegethon gravior? quae maior Erinys? 160 o stulti, quicumque deum dixistis Amorem. num natura nocens deus est? ubicumque locorum sit deus, est homini clemens, innoxius, aequus.

For. Heu miserande puer tenera sublate iuventa, quae tibi nascenti luxerunt sidera? quae tam noxia pars caeli est, ut te nil tale merentem laeserit et primis infortunarit $\mathrm{ab}$ annis? nec tamen omnino caelum tibi defuit; omne carmen et argutis quidquid modulamur avenis doctus eras. nisi te mors immatura tulisset, dignus eras hederis, dignus Parnaside lauro; nec melius cecinit pugnas ac tristia bella, hordea et agrorum cultus et pascua noster Tityrus a magno tantum dilectus Alexi. namque tui praecox animi sollertia nobis cognita iam pridem magnam producere frugem coeperat, et specimen tuleras virtutis et artis non vulgare tuae; poteras iam gloria dici ruris et aetatis deci $\triangle$ indelebile nostrae. te Padus et noster lugubri Mincius ore cum Nymphis flevere suis, ut Thracius Hebrus Orphea; te tristes ovium flevere magistri, ut Daphnim luxisse ferunt; te pascua et agri undique ; et audita est totis querimonia campis. spargite, pastores, tumulum redolentibus herbis atque sacerdotum cantus ac tura quotannis ducite, et aeternam requiem cantate poetae.

Fau. Tu tamen arva tenes patriae melioris et altum incolis Elysium; nos hic te flemus, Amynta.

For. Flendum hodie nobis fuerat; nam tristia nocte nescio quae maestis cernebam insomnia formis. sed iam Vesper adest et sol se in nube recondens, dum cadit, agricolis vicinos nuntiat imbres; cogere et ad caulas pecudes convertere tempus. 


\section{ECLOGA IV, ALPHUS,}

\section{DE NATURA MULIERUM.}

ALPHUS. IANNUS.

A. Ianne, caper (video) macer est tuus. esse solebat acer et elatis in caelum cornibus ire; nunc deiectus humi flaccis piger auribus herbam olfacit et summis attingit gramina labris.

I. Languet, et ex isto languore facetia surgit quae, quotiens memini, risum ciet. edita nondum est; edita cum fuerit, totus mirabitur orbis.

$A$. Ianne, soles narrare sales lepidissime et ore suaviloquo; dic ergo tuus cur langueat hircus.

I. Res non ficta (Deus testis) sed facta recenter. at dulce id facinus non est narrabile gratis; quid pretii sperare licet? quae dona reporto?

$A$. Ianne, ubi congessit nidos philomena docebo.

I. Qui leviter spondet promisso eludit inani.

$A$. Qui non credit, inops fidei. sed pignore tutum te faciam; duo tela mea deprome pharetra.

I. Incipiam. Nymphae Parnasides, ora movete et memorate mei dira infortunia capri, ac philomenaeos Alpho concedite nidos.

Conductus mercede puer praefectus ovili assidue pascebat oves, caprum atque capellas. servitium nobis pueri fuit utile, donec virgine conspecta quae tum huc veniebat aquatum tabuit. ex illo vecors iam tempore factus frigidius curare gregem, contemnere caulas coepit et exhausto subvertere cuncta cerebro. cum sopitus erat, poterat vigil esse videri, nugabatur enim; quando vigilabat, inerti corporis officio volvebat somnia mente. hunc ergo in saltu ludens per cornua caprum viminibus validis inter dumeta ligarat (quarta dies hodie) tentans an vincula possit vincere cervice ac pracdurae robore frontis, 
qua situm interea nidos nemus omne pererrat. corda subit virgo, dilecta recogitat ora, ora, sinus et quae fari pudor; omnia volvit. lux fugit interea ; capri redit immemor. alta nocte recordatus surgit, pavidusque per umbras dum graditur, ruit in foveam quae fronde saligna captandis obducta feris et stramine sicco 40 instar erat putei fundo irremeabilis alto. est caper in vinclis, puer est in carcere, pastor nullus oves curat. iam tertia luxerat hora; miror, oves resero ac numero caprumque requirens obstupeo ; puerum clamo, magalia lustro. vera loquar: magicis ne forte liquoribus unctus extimui ascenso migrasset in aëra capro. namque striges tali fama est ope nocte vagantes ad quaedam longinqua procul convivia ferri. attonitus tandem pecudes ad pascua duco. dumque pedum meditans subeo nemus, ecce per umbras, ecce procul caper in dumis strepit atque reluctans cornibus adversis contra sua vincula pugnat. terruit incautum subito feralis imago et nil tale ratum; firmato pectore tandem nosco animal subiensque rubos seco vincula runca. sero domum rediens video per pascua longe turbam exsultantem risu iuveniliter alto. ut prope constitimus meque agnovere, salutant et 'tuus ecce,' aiunt, ' puer hic, o Ianne, luporum erutus e foveis. dum nocte perambulat agros, incidit in casses.' et sic inventus uterque, et caper et pastor. caper haec incommoda passus languet adhuc; puer imprudens insanior hirco est. virgo superbivit mox, ut se audivit amari, et pueri simulans curam ignorare pudorem fingit, ut ad formam faciat pudor. ora sinumque ornat et in terram versis incedit ocellis callida; vulpina rem simplicitate gubernat. haec studia, hi casses, haec sunt mulieribus arma. ille sua sperans Galatea aliquando potiri contempta mercede suos sectatur amores. propterea plaustro, stiva bobusque relictis ad pastoris opus redeo; subiecta furori 
ista iuventutis levitas rura omnia vexat.

$A$. Quod nequit ingenium, casus facit. o stupor, o sors ingeniosa, o res risu celebranda bimestri! Ianne, fides servanda; tibi philomena laborat. sed quod tam vafro memoras de virginis astu rettulit in mentem quae psallere saepe solebat carmina femineis olim de fraudibus Umber.

I. Dic Umbri, dic, si quid habes. meditare parumper et verba et numeros; Umbri est memorabile carmen.

$A$. Est (ut ais) sed non gratis, memorabile carmen. quas referes grates? et quid mercedis habebo?

I. Accipe: promissis absolvo et spicula reddo.

$A$. Dum vado ad ventrem post hacc carecta levandum, Ianne, meum tu coge pecus, ne vitibus obsit.

I. O aries, aries, qui tortis cornibus atrum daemona praesentas, semper vineta subintras. 90 non sapies donec fossa tibi lumina fronte eruero. non sunt porrecta in iugera centum pascua sat, nisi pampineos populeris et agros.

$A$. Ianne, recordatus redeo, sed plurima forsan noridum nota tibi referam. cognoverat Umber omnia quae fas est homini perdiscere, caelos, sidera, tellurem, ventos, mare, flumina, fontes. viderat et Rhodopen atyue alta Ceraunia et Ossam, Gallica regna, Ararim, Rhodanum Tiberimque Padumque. Attica Romanis referebat carmina verbis 100 ore utroque potens et lingua primus utraque. hunc unum nobis invidit Graccia et ipsi Arcades et Thracum saltus et 'Thessala Tempe. si quid erit quod forte ve'is tibi notius esse, Candidus illius semper documenta secutus non procul hine; hace ille tenet, nos ille docebit. sed jam scptiforem flatu experiamur avenam. ante tamen Nymphac precor ut I.ibethricles adsint, praesertim quac plus meninisse lolymmia fertur.

- Femineum scrvile genus, crudile, superbum, lege, modo, ratione caret. confinia recti neglegit, extremis gaudet, facit omnia voto praecipiti, vel lenta iacet vel concita currit; femina semper hiems atque intractabile frigus, aut Canis ardentes contristat sidere terras. 
temperiem numquam, numquam mediocria curat; vel te ardenter amat vel te capitaliter odit.

- si gravis est, maeret torvo nimis hernica vultu;

si studeat comis fieri gravitate remissa,

fit levis, erumpit blando lascivia risu

et lepor in molli radiat meretricius ore. flet, ridet, sapit, insanit, formidat et audet, vult, non vult, secumque sibi contraria pugnat mobilis, inconstans, vaga, garrula, vana, bilinguis, imperiosa, minax, indignabunda, cruenta, improba, avara, rapax, querula, invida, credula, mendax, impatiens, onerosa, bibax, temeraria, mordax, ambitiosa, levis, maga, lena, superstitiosa, desidiosa, vorax, ganeae studiosa, palatum docta, salax, petulans et dedita mollitiei, dedita blanditiis, curandae dedita formae. irae odiique tenax in idonea tempora differt ulciscendi animos infida, ingrata, maligna, impetuosa, audax, fera, litigiosa, rebellis. exprobrat, excusat tragica sua crimina voce, murmurat, accendit rixas, nil foedera pendit, ridet amicitias, curat sua commoda tantum. ludit, adulatur, defert, sale mordet amaro, scminat in vulgus nugas, auditaque lingua auget et ex humili tumulo producet Olympum. dissimulat, simulat doctissima fingere causas ordirique dolos fraudique accomodat ora. ora omnes facili casus imitantia motu.

non potes insidias evadere, non potes astum vincere; tantac artes, sollertia tanta nocendi. et quamquam videas oculis praesentilus, audet excusare nefas. potis est cludere sensus seclulitate animi; nihil est quod credere possis ct nihil est quod non, si vult, te credere cogat.

II fucient exempla fidem. Ifuse crimina non sunt 150 feminea temptata manu? dedit hostibus arcem decepta ornatu bracchi 'Tarpeia sinistri, saeviit in natos manibus Medea cruentis. Tyndaris Aegaeas oneravit navibus undas, Scylla hostem sequitur patri furata capillum. fratrem Byblis amat, subicit se Myrrha parenti, 
concubitus nati longneva Semiramis ardet. causa necis vati coniunx fuit Amphiarao, occidere viros nocturnis Belides armis, Orphea membratim Cicones secuere poetam. 160 cognita luxuriae petulantia Pasiphaaeae, Phaedra pudicitiam contra crudeliter ausa est. decepit Iudaea virum Rehecca suamque progeniem velans hircino guttura tergo, porrigit Alcidae coniunx fatale venenum, decipit Hippodame patrem. Lavinia Troas implicat ancipiti bello, Briseis Achillem depulit e castris, demens Chryseide factus fulminat Atrides et sentit Apollinis iras. Eva genus nostrum felicibus expulit arvis. credite, pastores (per rustica numina iuro) pascua si gregibus vestris innoxia vultis, si vobis ovium cura est, si denique vobis grata quies, pax, vita, leves prohibete puellas pellanturque procul vestris ab ovilibus omnes, Thestylis et Phyllis, Galatea, Neaera, Lycoris. dicite, quae tristem mulier descendit ad Orcum et rediit? potuit, si non male sana fuisset. Eurydice revehi per quas descenderat umbras; rapta sequi renuit fessam Proserpina matrem. at pius Aeneas rediit, remeavit et Orpheus. maximus Alcides et Theseus et duo fratres, unus equis, alter pugnis bonus atque palaestra, et noster Deus, unde salus et vita resurgit. haec sunt, pastores, haec sunt mysteria vobis advertenda : animi fugiunt obscena viriles, femineas loca delectant infamia mentes.'

Ut semel in scopulos vento contortus et unda nauta scit incautis monstrare pericula nautis, sic senior longo factus prudentior usu praeteritos meminit casus aperitque futuri temporis eventus vitaeque pericula monstrat.

' Si fugiunt aquilam fulicae, si retia cervi, si agna lupum, si damma canem, muliebria cur non blandimenta fugis tantum tibi noxia, pastor? est in eis pietas crocodili, astutia hyaenae ; cum flet et appellat te blandius, insidiatur. 
femineos, pastor, fugito (sunt retia) vultus; non animis, non virtuti, non viribus ullis fidito, non clipeo cuius munimine Perseus vidit saxificae colubros impune Medusae. monstra peremerunt multi, domuere gigantes, evertere urbes, legem imposucre marinis fluctibus, impetui fluviorum et montibus aspris, sacra coronarunt multos certamina; sed qui cuncta subegerunt sunt a muliere subacti. rex qui pastor erat funda spolioque leonis inclutus, et natus qui templa Sionia fecit primus, et excellens invicto robore Samson femineum subiere iugum; minus officit ignis, saxa minus, rhomphaea minus, minus hasta, minus mors. nec formae contenta suae splendore decorem auget mille modis mulier: frontem ligat auro, purpurat arte genas et collocat arte capillos, arte regit gressus et lumina temperat arte. currit, ut in latebras ludens perducat amantem; vult dare, sed cupiens simplex et honesta videri denegat et pugnat; sed vult super omnia vinci. femina Caeciaco (res mira) simillima vento est qui trahit expellens mendaci nubila flatu. quisquis es (expertus moneo) temptare recusa, dum licet, hic fragilis quot habet fastidia sexus. immundum natura animal, sed quaeritur arte mundities; id luce opus est, ea somnia nocte. deglabrat, lavat et pingit, striat, unguit et ornat tota dolus, tota ars, tota histrio, tota venenum. consilio speculi gerit omnia; labra movere discit et inspecto vultum componere vitro, discit blandiri, discit ridere, iocari, incedens umeros discit vibrare natesque. quid sibi vult nudum pectus? quid aperta superne rimula quae bifidam deducit in ubera vallem? nempe nihil, nisi quo virus penetrabile sensum plus premat et Stygiae rapiant praecordia flammae. hi iuvenum scopuli, Syrtes, Scyllae atque Charybdes; hae immundae Phinei volucres quae ventre soluto proluvie foeda thalamos, cenacula, mensas, compita, templa, vias, agros, mare, flumina, montes 
incestare solent; hae sunt Phorcynides ore monstrifico extremis Libyae quae in finibus olim aspectu mutare homines in saxa solebant.'

Carmina doctiloqui cursim recitavimus Umbri. quae si visa tibi nimium prolixa, memento ipsius id rei vitium, non carminis esse.

non longum est carmen, mulierum amentia longa est.

I. O memorande senex, quo se vetus Umbria tantum iactat et ipse tuae 'Tiberis conterminus urbi, Martia non ab re tantum te Roma vocalat. ipsa tuas artes et non trivialia norat carmina. te vita functum flevere Iatinae Naiades et Graiae. tua molliter ossa quiescant semper et in summo mens aurea vivat Olympo. 


\section{ECLOGA V, CANDIDUS,}

\section{DE CONSUETUDINE DIVITUM ERGA POETAS.}

\section{SILVANUS. CANDIDUS.}

S. Candide, nobiscum pecudes aliquando solebas pascere et his gelidis calamos inflare sub umbris et miscere sales simul et certare palaestra; nunc autem quasi pastores et rura perosus pascua sopito fugis et trahis otia cantu.

$C$. Vos quibus est res ampla domi, quibus ubera vaccae plena ferunt, quibus alba greges mulctraria complent, cymbia lacte nivent et pinguia prandia fumant, carmina laudatis; si quid concinnius exit, plauditis ac laeti placidas extenditis aures. pro numeris vanas laudes et inania verba redditis; interea pastor sitit, esurit, alget.

$S$. . Nonne potes curare greges et dicere versus, cum vacat, et positis vitam traducere curis?

$C$. Omnem operam gregibus pastorem impendere oportet, ire, redire, lupos arcere, mapalia saepe cingere, mercari paleas et pabula, victum quaerere; nil superest oti. laudabile carmen onnem operam totumque caput, Silvane, requirit. grande utrumque opus est et nostris viribus impar. cum cecini, sitio ; sitienti pocula nemo porrigit. irrident alii : 'tibi paenula,' dicunt, 'Candide, trita, genu nudum, riget hispida barba.' iam silvae implumes et hiems in montibus albet : irascor, doleo, indignor. fert omnia victus, lanitium fetusque mares non vendimus agnas, sed, quia lac pascunt, premitur nihil; ubera siccant.

- paenitet ingenii, si quid mihi, paenitet artis, paenitet et vitae, postquam mihi nulla secundant ex tot sideribus quot sunt in nocte serena. hactenus (ut nosti) gratis cantavimus; aetas indiga paucorum merces fuit; altera longe condicio senii quod nunc subit: omnium egenos 
reddit et exstinctis lucri spem viribus aufert. mox erit utendum partis, modo quaerere tempus.

en formica, brevis sed provida bestia, condit in brumam nova farra cavis aestate latebris, neve renascantur fruges secat ore sepultas.

$S$. Scire genethliacos fatalia sidera dicunt. hi sub Mercurio vates et sub Iove reges magnatesque locant; istis dat Iuppiter aurum atque magistratus, dat Maiae filius illis ingenium, linguam, citharas et carminis artem. haec tua sors; quid quaeris opes? Deus omnia in omnes dividit, ut melius nobis videt esse futurum. sorte tua contentus abi, sine cetera nobis.

C. Sunt tibi divitiae, mihi carmina; quid petis ergo carmen et invadis partes, Silvane, alienas?

$S$. Non tibi surripio carmen nec Apollinis arma, sed dare dulcisonis aures concentibus opto.

$C$. Si gaudere meis igitur concentibus optas, nos gaudere tuis opibus, Silvane, decorum est.

$S$. Ille meis opibus gaudet qui diligit; odit invidus atque animo bona fert aliena molesto.

$C$. Sic quoque tu nostris absens gaudere Camenis sat potes; haec artis sat sint tibi gaudia nostrae. carmina sunt auris convivia, caseus oris ; si cupis auditu, fac nos gaudere palato. hoc amor, hoc pietas, hoc vult Deus; omnia non dat omnibus, ut nemo sibi sit satis indigeatque alter ope alterius, quace res coniungit in unum omne genus, Gallos, Mauros, Italos et Iberos. sidera iungamus: facito mihi Iuppiter adsit, et tibi Mercurius noster dabit omnia faxo, pilleolum, virgam, citharas, nodum Herculis, alas.

$S$. Vana supervacuis inculcas plurima verbis.

$C$. Vana inquis quae damna tuis inferre videntur divitiis. si vis nostras audire Camenas, erue sopitam de sollicitudine mentem; vult hilares animos tranquillaque pectora carmen. torpeo, ut esuriem patiens et frigora milvus, iamdudum squarrosa cutis, situs occupat ora, nec pecus in stabulis, nec in agro farra, nec aurum in loculis; et vis positis me vivere curis? 
non facit ad nostros talis medicina dolores. fac alacrem, tege, pasce, gravi succurre senectae; invenies promptum versu et cantare paratum. plena domus curas abigit, cellaria plena, plena penus plenique cadi plenaeque lagenae, horrea plena, greges laeti, gravis aere crumena. tunc iuvat hibernos noctu vigilare Decembres ante focum et cineri ludos inarare bacillo, torrere et tepidis tostas operire favillis castaneas plenoque sitim restinguere vitro fabellasque inter nentes ridere puellas. 'Tityrus (ut fama est) sub Maecenate vetusto rura, boves et agros et Martia bella canebat altius et magno pulsabat sidera cantu. eloquium fortuna dabat; nos, debile vulgus, pannosos, macie affectos, farragine pastos Aoniae fugiunt Musae, contemnit Apollo.

$S$. Si sperata mihi dederit fortuna quod opto, Candide, praesenti te sollicitudine solvam.

C. O utinam, Silvane, foret tibi tanta voluntas quanta est hac etiam tibi tempestate facultas. non ego divitias Cosmi, non Serica posco pallia, non Tyrias chlamydes, non prandia regum, non patinam Aesopi fameo clipeumve Minervae; nil opus est regis laribus cui ferrea nomen tradidit aut, si mens non fallitur, aenea barba (haec me iam pridem memini didicisse sub Umbro) postulo vestitum, peto victum sub lare parvo certior istud opis toti non defore vitae; sint milhi Pythagorae mensae Codrique supellex. saepe alios qui spem dederint invenimus ore magnificos, sed re modicos; tibi fidimus uni. tu mihi si fueris mendax, praeciditur omnis spes, ut solstitio fiam philomena reverso mutus et elinguis. suspendere postibus arma tempus erit clausoque abigi spectacula circo.

$S$. Candide, vidisti Romam sanctique senatus pontifices, ubi tot vates, ubi copia rerum tantarum? facile est illis ditescere campis.

$C$. Deciperis me velle putans ditescere. vesci et lupus omne animal crudis existimat escis 
tuque putas alios quo tu pede claudere passum. non ego ditari cupio, sed vivere parvo. fac habeam tenuem sine sollicitudine victum; hoc contentus eam. Romana palatia vidi, sed quid Roma, putas, mihi proderit? o Silvane, occidit Augustus numquam rediturus ab Orco. si quid Roma dabit, nugas dabit. accipit aurum, verba dat. heu Romae nunc sola pecunia regnat; exsilium virtus patitur. sperare iubemur undique et in toto vates spe pascimur orbe.

$S$. Dic pugnas, dic gesta virum, dic proelia regum, vertere ad hos qui sceptra tenent, qui regna gubernant; invenies, qui te de sordibus eruat istis.

$C$. Inveniam qui me derideat et subsannet. tempestate ista reverentia tanta poesi quanta fupanari; quid me, Silvane, lacessis?

$S$. Non decet obscenis vatem prorumpere verbis.

$C$. Non possum non vera loqui. si vera taceri forte velis, levilus me parce lacessere dictis.

$S$. Utile consilium praestare lacessere non est.

$C$. Consilii locuples ego, sed pauperrimus auri. qui pugnas, qui gesta virum, qui proelia regum dicet inops vates cui nec quo fistula possit aptius incidi fierique foramina culter? aspice ut excussis luxata manubria clavis, 140 ut dentata acies veterique simillima serrae. hoc leve, sed mensae grave et intolerabile damnum. utile consilium firmat, sed inutile mentem frangit et extenuat vires animumque retundit. magnates dare parva pudet, dare magna recusant. adde quod et nostri curant ita carmina reges ut frondes Aquilo, mare Lilss, vineta pruinae. ipsi ad delicias reges et ad otia versi quod celebrant laudari optant; hinc carmina manant perdita de studio Veneris, de scurrilitate, de ganea, de segnitie, de infamibus actis quae castum capitale nefas celebrare poetam. at qui dura manu gesserunt bella potenti fortiter utentes ferro, non molliter auro, dilexere graves Musas; heroica facta qui faciunt reges heroica carmina laudant. 
ut cessere viri fortes et mascula virtus, dicendum altiloqui nihil invenere poetae; occidit ingenium vatum, ruit alta poesis. at si forte aliquis regum gerit aspera bella et decus armorum studiis belloque paravit, nil genus externum venturaque saecula curat laude suae gentis satur et praesentibus annis; barbarus est neque carmen amat vel avarus in auro mergitur atque Midae curis flagrantibus ardet. est et apud reges rudis, invida, rustica turba, mimus, adulator, leno, assentator, adulter, histrio, scurra, quibus virtus odiosa ; poetas mille modis abigunt, ut quando cadavera corvi invenere, fugant alias volucresque ferasque. sunt etiam vates quidam sine lege petulci qui sine lege aliti sine praeceptoribus audent quidquid amant reges (et amant infamia solum) scribere; nam vates etiam dementia vexat. hi se nescio qua mentis levitate poetas esse volunt. postquam trivialibus ora cicutis applicucre, sibi applaudunt, sua carmina iactant insulsi, illepidi, indociles, improvidi, inepti. qui solet his vacuas praebere ambagibus aures id vitium commune putat doctisque resistit vatibus a vero indoctus discernere falsum.

$S$. Candide, per Superos, per Olympica numina iuro me tibi, si venti veniant ad vela secundi, laturum auxilium. meliora in tempora vive nec paulisper adhuc mecum sperare recusa.

$C$. Si mihi sic optas, tibi sit, Silvane, quod optas.

$S$. Opto equidem, dictumque fides non sera sequetur.

$C$. Vade malis avibus numquam rediturus, avare, et facias subito quidquid tractaveris aurum more Midae, quando virtus tibi vilior auro. 


\title{
ECLOGA VI, CORNIX,
}

\section{DE DISCEPTATIONE RUSTICORUM ET CIVIUM.}

\author{
CORNIX. FULICA.
}

C. Ningit hiems, mugit Boreas, a culmine pendet stiria ; depositis bobus requiescit arator, dormit humus; clauso pastor tunicatus ovili cessat iners, sedet ante focum fumosa Neaera atque polenta coquit. prius intolerabilis aestas nunc laudatur, hiems aestu laudata molesto displicet; optatum damnat praesentia frigus.

$F$. Omne bonum praesens minus est; sperata videntur magna, velut maius reddit distantia lumen.

C. Delicias habet omne suas et gaudia tempus. aspice ut impexi tritaque in veste ligati caede suum pueri exsultant. inflatur in utrem immissis vesica fabis; sonat et micat acta nunc pede, nunc cubito, stricto nunc obvia pugno. si cadit, attollunt; cursu labor atque recursu brumam abigit; glaciale gelu pila rustica vincit. nos tamen hic melius tepido sub stramine foti transigimus tempus, dum lac coit igne recoctum.

$F$. Pauperiem declarat hiems. improvida certe turba sumus iuvenes; securi aestate vagamur immemores hiemis, nostrum aes tibicinis omne est ; ut redit e Scythia Boreas nidosque volucrum frondibus ostendit nudata cadentibus arbor, frigemus nudi scapulas, dorsum, ilia, plantas. stultitiam declarat hiems. sapientius urbes congeriem nummum accumulant et ad ilia vulpes melotasque trahunt maculosaque tergora lyncis.

$C$. Desipiunt omnes nec nos in crimine soli. immo ipsos vexat gravior dementia cives, verum illis mater nobis Fortuna noverca nos premit. infelix sors est dementia. fac sim fortunatus, ero locuples, ero primus in urbe, audiar, assurgent omnes, me vertice nudo 
vulgus adorabit, me plebs, me consulet omnis turba, magistratus etiam populusque patresque.

F. O Cornix, Cornix, non est Fortuna sed ipse quo sapiunt homines animus. Fortuna potentem non facit, immo Deus; causam recitabat Amyntas.

C. Est Fortuna Deus. sed quid recitarit Amyntas dic, precor ; in causis erat ingeniosus et acer. ante tamen paulum pecus et praesepia vise. vade, redi ; calor est post frigora dulcior; ito.

$F$. Attingit nix alta genu, vix tecta resistunt tanto oneri; sublimis apex in vertice furni pyramidem fecit metaque assurgit acuta.

C. Da pecori cordum stipulisque foramina claude, si paries hiat, et rediens laetamine muni limina; nulla gregi gravior quam frigora pestis. iamne ades? oh quaenam haec solito properantia maior?

$F$. Sollicitum me reddit hiems; in frigore et igni maxima strenuitas; faeno recubare calenti abscondique cavo accubitu post frigora dulce est.

$C$. Incipe, et enarra discrimina ruris et urbis.

$F$. Hoc igitur tantum ruris discrimen et urbis taliter exortum noster recitabat Amyntas.

Principio rerum primaque ab origine mundi cum muliere marem sociali foedere iungens caeli Opifex (sic namque Deum appellabat Amyntas; nomen adhuc teneo) natos producere iussit atque modum docuit fieri quo pignora possent. accinxere operi, mandata fideliter implent ; sicque utinam de pomi esu servata fuissent. femina fit mater, puerum parit atque puellam, atque puerperio simili fecunda quotannis auxit in immensum generis primordia nostri. post tria lustra Deus rediit. dum pignora pectit femina prospiciens venientem a limine vidit. Adam aberat, securus oves pascebat; adulter nullus adhuc suspectus erat; sed multiplicatis conubiis fraudata fides, sine cornibus hirci facti, et zelotypo coniunx suspecta marito. nam quae quisque facit fieri sibi furta veretur. erubuit mater nimiaeque libidinis ingens indicium rata tot natos abscondere quosdam 
accelerat; faeno sepelit paleisque recondit. iamque lares Deus ingressus salvere penates iussit et ' huc,' dixit, 'mulier, tua pignora profer.'

femina maiores natu procedere mandat. his Deus arrisit, velut arridere solemus exiguis avium pullis parvisve catellis.

et primo laetatus ait, "cape regia sceptra; rex eris.' at ferrum et belli dedit arma secundo et ' dux,' inquit, ' eris.' fasces populique secures protulit et vites et pila insignia Romae. iamque magistratus celebres partitus in omnem progeniem humanos tacitus volvebat honores. interea mater rebus gavisa secundis evolat ad caulas et quos absconderat ultro protulit 'haec,' dicens, 'nostri quoque pignora ventris; hos aliquo, Pater omnipotens, dignabere dono.' setosum albebat paleis caput, haeserat armis stramen et antiquis quae pendet aranea tectis. non arrisit eis, sed tristi turbidus ore 'vos faenum, terram et stipulas,' Deus inquit, 'oletis. vester erit stimulus, vester ligo, pastina vestra; vester erit vomer, iuga vestra, agrestia vestra omnia; aratores eritis pecorumque ma;yistri, faenisecae, solifossores, nautae atque bubulci. sed tamen ex vobis quosdam donabimus urbe qui sint fartores, lanii, lixae artocopique et genus hoc alii soliti sordescere. senıer sudate et toto servite prioribus aevo.'

taliter Omnipotens fatus repetivit Olympum.

Sic factum est servile genus, sic ruris et urbis inductum discrimen ait Mantous Amyntas.

C. Mirabar si quid recti dixisset Amyntas. civis erat; semper nobis urbana juventus cui nihil est praeter stulta haec commenta negoti ludit; in agrestes semper iaculantur, et urbis talia garrulitas et vaniloquentia fingit. at neque de Superis pudet has componere nugas. iste iocus manifesta gerit convicia secum, sed tu tam rudis es, tam pleno inflatus cmaso, ut neque perpendas isto te scommate carpi. nos quoque paulisper mentem extendanıus ad urbis 
stultitiam, ne forte putes sapientius illos vivere qui splendent auro, qui murice fulgent.

His oculis vidi tunicis plerosque superbis vestiri atque foro regali incedere gressu quos secreta fames premit atque domestica egestas. stultius his certe nihil est; opulentia ficta, paupertas et segnities et inertia vitae vera, quid est aliud quam desipientia vera? vidi etiam patres (o rem indignam atque nefandam) dum segnes dormire volunt et vivere laute, prostituisse suas vulgo cum coniuge natas; quid peius? quid perfidius? quid stultius umquam?

$F$. Quid si vitam alio nequeunt traducere pacto?

$C$. Cum totidem quot nos habeant animasque manusque, dic cur vitam alio nequeant traducere pacto. 130

Est etiam cuius vecors industria vanas quaerat opes, ubi nullus opes invenit ab aevo: aes lavat herbarum sucis et vertere in aurum aestimat ac nigra semper fuligine pallet. est qui, dum tellure latens desiderat aurum, dat magicis operam studiis et tempora perdit; quid levius? quid futilius? quid inanius umquam? omnia, ne veniant ad opus telluris et agri, omnia pertemptant; ut agant nihil, omnia versant. semper agunt, numquam peragunt. ex faenore victum infamem extorquent ; vi, fraude dolisque laborant. mille viis opibus, mille insidiantur honori. nos capras et oves armentaque pascimus, illi accipitres, catulos et equos et cercopithecos. rusticus est ovium pastor, volucrumque canumque civis; utrum melius, te iudice, nobiliusque, o Fulica, utilitas unde et opulentia maior?

$F$. Si venit ex nostris operis opulentia maior, civibus unde igitur tantarum copia rerum?

$C$. Ex vi, fraude, dolis; vi, fraude dolisque laborant. 150 nonne vides, insane, ut nos crudeliter urgent, quo capiunt astu? nos irretire loquendo sacrum offerre putant et opus sublime piumque. huc aures oculosque adigunt, huc ora manusque.

$F$. Unde urbanarum tibi tanta peritia rerum?

$C$. Haec didici quondam ductis in moenia capris, 
cum lac vociferans ibam venale per urbem. mansi apud artocopum. sapiens et ad omnia promptus furta erat et crudum ferro subradere panem. ipse, ut erat mores urbis doctissimus, ista tradidit affirmans nihil esse nocentius urbe; se quoque furari didicisse aiebat $a b$ urbe.

Sunt etiam qui parta ab avis patrimonia fundunt in meretricum usus; quid foedius improbiusque? dic, ubi moechandi ars, homicidia, seditiones? nonne inter cives atque intra moenia regnant? quid reges qui regna hominum per vulnera quaerunt in mortemque suos adigunt? quid pectora miles obiciens telis, per mille pericula vadens? pro stipe dat vitam; nulla est insania maior. gloria praefertur vitae; quid gloria? quid laus? quid fama est? quid honor? voces et opinio vulgi. omnia longa dies abolet; cum vivere cessas, omnia sic abeunt, ut lux cum sole recedit. qui mare sollicitant remis, cum vivere possint in patria, stulti ; vento qui credit et undis, stultus ; divitiac cui sunt et neglegit uti, stultus; qui, ut natis cumulet patrimonia, partis abstinct et genium fraudat, stultissimus, et qui quae facere ipse potest natis faciunda relinquit. qui numerant stellas et se comprendere fata posse putant, stulti ; verum dementior istis naturam quicumque Dei scrutatur et audet figere in immensam lumen tam debile lucem. nostra fides melior. civis ratione coactus difficile assentit; nudis nos omnia verbis credimus et plures faculas accendimus aris. civibus est infida fides; inquirere numquam mente sinunt arcana Dei. si numina scire esset opus, poterant nobis se ostendere ; verum, quando latere volunt, quid vestigare necesse est quae nos scire negant ipsi qui cuncta gubernant? nostra etiam pietas pietate potentior urbis. namque viri qui sacra canunt templisque ministrant quanta legunt ruri paucis alimenta diebus? vidi ego quaesitas ex rlire in moenia plenis puppibus inferri (pietas ea rustica) fruges. 
stultorum est aliud genus immedicabile quoddam, causidici latratores rabulaeque forenses nummorum aucupium docti legumque tyranni. aere patrocinium vendunt; producere causas et lites pendere diu vindemia quaedam est. sunt et equestre genus medici qui tangere venas non numquam illicitas audent et ponere quaedam non intellectis temeraria nomina morbis. his, etsi tenebras palpant, est facta potestas excruciandi aegros hominesque impune necandi. qui vero in populis praesunt hominesque gubernant quo plus iuris habent quantoque licentia maior insanire solent tanto amplius. o ubi sancti rectores et iustitiae et pietatis amici quos patres sero ante focum memorare solebant? omnia nunc abeunt pessum. spoliata queruntur templa, gemunt inopes, viduae lacrimantur, et huius quaenam causa mali? quia stat pro lege libido.

$F$. Ista tua, o Cornix, excandescentia fines transit honestatis; scelus omnibus obicis omne. innocuos habitare homines et in urbe memento.

C. Non habitant colubri quacdam Balearibus arva proxima (non memini nomen) neque noctua Cretam, nec nemus Egeriae sonipes, nec vir bonus urbem.

$F$. Vir bonus est animal rarum paucasque per urbes et per rura locos habet; est rarissima virtus.

$C$. Insanis, Fulica, insanis ; tot in urbibus hostes sunt tibi quot cives. hi nos tondentque pilantque non habita nostri capitis ratione; coartant nos ad furta, ipsi mox ad suspendia mittunt. fas igitur, si quid nostris sese unguibus offert, radere et insidiis ac nostra indagine captos deplumare levi tactu sensim et pedepressim. si videt, excusa; si sunt secreta, negato furta; quod occultum est non est iniuria furtum. quidquid habent noster labor est, industria nostra est.

$F$. Iam longe egrederis metam rationis et aequi.

C. O Fulica, improbitas urbana coinquinat orbem. unde tot in terras veniunt aestate procellae, fulmina, venti, amnes, grando? vidisse recordor tellurem tremere ac postes et tecta lahare, 
solem obscurari, noctu obtenebrescere lunam. cur segeti lolium, messi dominantur avenae, uva in capreolos transit, caligine verni depereunt flores? mala parturit omnia nobis haec civile nefas, pariet quoque plura deinceps. unde venit furor armorum bellique tumultus qui genus omne mali secum vehit? omnibus urbs est fons et origo malis. descendit ab urbe Lycaon, Deucalion Pyrrha cum coniuge rusticus. ille intulit illuviem terris, hic abstulit; ille abstulit humanum terris genus, intulit iste. si terra (ut perhibent) flammis abolebitur umquam, istud grande nefas ulla descendet ab urbe.

$F$. O Cornix, iam pone modum sermonibus istis; audio iamdudum pueros de pulte loquentes. cetera, si quicquam superest, post prandia dices; pulti indulgendum monet urbibus hora relictis. 


\section{ECLOGA VII, POLLUX,}

\section{DE CONVERSIONE IUVENUM AD RELIGIONEM, CUY IAM AUCTOR AD RELIGIONEM ASPIRARET.}

\section{ALPHUS. GALBULA.}

A. Galbula, quid sentis? Pollux doctissimus olim fistulicen subito quodam quasi numine tactus destituit calamos, tunicas, armenta, sodales; bardocucullatus caput ut campestris alauda quattuor ante dies in religiosa recessit

claustra. ferunt illum, pecudes dum solus in agris pasceret, effigiem quandam vidisse deorum. cetera non memini, sed tu quid, Galbula, sentis?

$G$. Ut dixere patres, iaciens primordia rerum (magna canam nobis quae quondam tradidit Umber) 10 instituit Deus agricolas pecorisque magistros.

- primus agri cultor rudis, immansuetus et asper qualis humus segnis, lapidosa, rebellis aratro. ast ovium primus pastor, mitissima proles, instar ovis quae bile caret, quae lacte redundat, mitis erat, nullis umquam pastoribus asper. de grege saepe suo sacrum ponebat ad aras; nunc ove, nunc pingui vitulo faciebat, et agno saepius, et magno divos ambibat honore. sic profecit apud Superos, sic numina flexit, ut fuerit primo mundi nascentis ab ortu tempus ad hoc caelo pecoris gratissima cura. Assyrios quosdam (sed nescio nomina; curae diminuunt animum) Deus ex pastoribus olim constituit reges qui postea murice et auro conspicui gentes bello domuere superbas. cum Paris Iliaca tria numina vidit in Ida (aut Paris aut alius puerum qui obtruncat ad aram) pastor erat. quando caelesti exterritus igne venit ad ostentum pedibus per pascua nudis, pastor erat Moses, Moses a flumine tractus. exul apud Graios Amphrysia pastor Apollo rura peragravit posito deitatis honore. 
caelestes animi Christo ad praesepia nato in caulis cecinere Deum pastoribus ortum, et nova divini partus miracula docti pastores primi natum videre Tonantem, et sua pastores infans Regnator Olympi ante magos regesque dedit cunabula scire. se quoque pastorem Deus appellavit, ovesque mitilus ingeniis homines et mentilus aequis. et, ne vana putes haec somnia, nuper ab urbe rus veniens picto perlegi hace omnia templo. sunt pecudes pictae, parvi sub matribus agni in tellure cubant, ingens equitatus ab alto monte venit, radiant auro diademata divum et suspensa tenent vaga lumina praetereuntum. non igitur mirum noster si numina Pollux vidit; amant villas et oves et ovilia divi. simplicibus praesens Deus est, offenditur astu.

$A$. Vera refers. pecori sic sint innoxia nostro pascua, vidi asinum, vidi praesepe bovemque. iam memini turbae venientis, et ora videre Indica iam videor regum sua dona ferentum. unum oro, quaenam Polluci occurrit imago? Galbula, si nosti, ne sit labor omnia fari.

$G$. Et novi et memorare libet ; res digna relatu, res digna audi!: pia, sancta, imitabile factum.

Durus et imriitis pater atque superba noverca Pollucem graviore iugo pressere iuventac 60 tempore cum dulces animos nova suggerit actas; et cum iam invalidae longo sub pondere vires deficerent nullaque odium mansuesceret arte, constituit temptare fugam. res una volentem ire diu tenuit: nimis impatienter amabat; error enim communis amor iuvenilibus annis. res est fortis amor, violentia fortior; ivit. et tales abiens (mihi namque solebat amores enarrare suos) maesto dedit or: querellas :

' O virgo, lacrimaene tuis solventur ocellịs cum te tam caro cernes ab amante relictam? ullane discessu duces suspiria nostro? tune mei crudelis eris forte immemor umquam? usqueadeone tuum poterit frigescere pectus, 
pectus quod totiens quod lumina fletibus implet? tune trahes crebros gemitus et pallida fies? cerno oculos, cerno lacrimas, cerno anxia corda virginis. heu tantum qua dissimulare dolorem fas erit arte? dolor duplex mea pectora torquet, illius atque meus. sed fas mihi flere, quod illi non licet; occultus longe magis aestuat ignis. incolumem mihi vos, divi, servabitis illam, ut, quando exsilio repetam mea rura peracto, fiat amor felix saltem semel ante senectam.'

'Talia pergebat memorans, voluitque reverti (tantus amor juvenem, vis tanta furoris agebat) sed iam iacta fuga cunctis erat alea nota. fronde sub Herculea fessus maerore sedebat; ecce puellari virgo stipata corona ora, manus, oculos habitumque simillima Nymphae, et tali affata est puerum sermone dolentem: Care puer, quo tendis iter? vestigia verte. nescis, heu nescis-quo te via ducat et audes ignotis errare locis nihil insidiarum per campos ratus herbosos, nihil esse pericli. omnia tuta putas et quod placet utile credis more iuventutis stolidae. collectus in orbem saepe latet molli coluber sub graminis umbra; est facile incautos offendere. parvulus infans innocuos rutilum digitos extendit in ignem nec nisi jam laesus vires intellegit ignis. haec regio intrantes aditu consuevit amoeno fallere, delicias offert et gaudia; verum ingressis, cum triste nihil superesse putatur, mille parat laqueos et mille pericula profert. trames hic, ut collem gressu superaveris illum, ducit in umbrosam silvam, crudele ferarum hospitium, loca taetra situ et caligine opaca. quisquis eo deceptus abit remeare vetatur, et piceis primum velatur lumina vittis, deinde per. omne nemus, dumeta per aspera tractus transit in effigiem monstri. dum volvere linguam atque loqui temptat, mugit; dum attollere sese credit, humi graditur quadrupes neque suspicit astra. ima tenebrosae vallis lacus aequore nigro 
occupat et nigris mons plurimus imminet undis. huc tracti in Stygios latices altumque barathrum praecipites dantur rapidaque voragine mersi in Styga et aeternas Erebi rapiuntur in umbras. heu quot pastores istis ambagibus acti cum gregibus periere suis! ego sedula semper monstro iter; hic ad opem vigilo indefessa ferendam. tolle moras igitur, mortis fuge blanda propinquae atria ; secreti tutam pete littoris oram qua contra Idalios fluctus mihi tollit in altum aëra Carmelus viridi caput arbore cinctum. primus hic antiquis patribus spelaea domosque praebuit arboreas intra nemus ilice densum. ex hoc in vestros deducta cacumine montes religio venit, sicut de fonte perenni

flumina, et ex uno multi genitore nepotes. illius in silvis abies ubi plurima surgit, pinguis ubi piceae sudat liber et terebinthi, innocuum postquam feliciter egeris aevum, mox tua mutatis aetas renovabitur annis. in loca te tollam melio a virentia semper; immortalis eris divum comes, ire per astra inter Hamadryades et Oreadas atque Napaeas flore coronatas caput et redolentibus herbis fas erit ac super et subter cognoscere caelos.'

Sic effata leves virgo discessit in auras. tum sua iuravit Pollux mutata repente pectora et extemplo victum exspirasse furorem non aliter quam flamma cadet, si ardentibus agris effluat et totas praeceps Padus evomat undas. sic abiit crudelis Amor qui saepe pharetram in iuvenem, dum principiis obstaret amandi, dum tepet ac timide insanit, consumpserat omnem. sic igitur Pollux in claustra silentia venit.

$A$. Sunt quibus aspirent etiam nolentibus ultro, sunt quibus infensi sine causa et crimine di sint.

$G$. Quod nos in pecudes, in nos id iuris habent di ; hoc rus scire sat est, sapiant sublimius urbes. sic docuit rediens aliquando ex urbe sacerdos Iannus et in magno dixit sibi codice lectum.

$A$. Sol cadit et Baldi vix summa cacumina tangit; 
nos quoque iam sero cum sole recedere tempus. Galbula, sarcinulas ne sit tibi ferre molestum, pera levis, levis est et cantharus; omnia parvus ferre labor sero, grave mane sed utile pondus. ipse pecus ducam, mihi pars erit ista laboris. 


\section{ECLOGA VIII, RELIGIO,}

\section{DE RUSTICORUM RELIGIONE.}

\section{CANDIDUS. ALPHUS.}

C. Horrida solstitio tellus sitit, Alphe, reverso; ad solitos montes, ubi ros in gramine et aestas mitior, haec armenta monet deducere tempus.

$A$. Aerios montes et summa cacumina longe prospicio; quid sint montes (tibi vera fatebor) nescio, semper enim campestria rura lacusque incolui. montanus ager qua fruge redundat?

$C$. O rude et illepidum ingenium. prope flumina semper versatus fulicae in morem limosa per arva, sunt ubi ranarum, culicum, pulicum cimicumque 10 lustra, inter salices, ulvas viridesque papyros, irridere audes et nauci pendere montes. unde fluunt amnes? templis ubi tanta locandis marmora caeduntur? fulgens ubi nascitur aurum? quae parit antemnas tellus? medicamen ab herbis, dic, quibus est nisi montanis? de vertice Baldi saepe melampodion legi ; medicina capellis nulla magis praesens. quondam Valsasinus Aegon tradidit hoc, dum vere sues castraret et agnos; tradidit et dixit, ' solus medicamen habeto.' dic, ubi castaneae plures? ubi copia maior glandis? in excelsis fontes et pascua vidi montibus, artocreas et pingue polenta comedi. sunt populi fortes illic. robusta iuventus lata pedes, callosa umeros, nervosa lacertos, hispida, dura manus, moli indefessa ferendae vallibus ex illis, onera ut navalia curet, confluit huc. nullum est hominum genus aptius urbi, sive velis castrare pecus, seu scindere fagos, sive fimum ferri e stabulis, haurire cloacas latrinasque curare viamque aperire coactis sordibus et scalis puteos descendere in altos; ingenio callent et duro robore pollent. 
sed quid opus multis? subeunt opus omne : popinis inservire, focos lignis cumulare veruque artifici versare manu, dare libera fumo spiramenta, boum ventres ad flumina ferre, verrere humum immundam scopis doctissima gens est; quodque magis miror, semper sub pondere currunt. cotibus in duris oriuntur et ardua vivunt per iuga ; cum capreis habitant spelaea ferarum. adde quod in caelum brevis est e montibus altis transitus; erectum caput usque ad nubila tollunt. nubila transcendunt aliqui, puto sidera tangant. esse locum memorant, ubi surgit ab aequore Titan, qui (nisi dedidici) contingit vertice lunam, et vixisse illic hominem, sed postea abactum improbitate gulae, quod scilicet omnia poma manderet et magno servaret nulla 'Tonanti. hinc divi sanctique patres in montibus altis delegere domos tacitas ; Carthusia testis, Carmelus, Garganus, Athos, Laureta, Laverna et Sina et Soractis apex Umbrosaque Vallis et iuga Nursini fato senis incluta et altis abietibus turrita caput Camaldula sanctum. cetera praetereo, nec enim sermonibus istis omnia complecti statuo. montana frequentant culmina caelicolae, sed anas et mergus et anser, ibis, onocrotalus, milvi fulicaeque paludes.

$A$. Inter montanae tantos regionis honores cur de messe nihil, nihil est de palmite dictum? haec tamen humanae duo sustentacula vitae maxima. monticolae veniunt e rupibus ad nos hordea mercatum torvi, fuligine tincti, saetosi, macie affecti, laceri ac situosi ; indigenae ostendunt quae sit natura locorum. sed quod montanis de religionibus inquis rettulit in mentem quae de Polluce feruntur. quae dea, si nosti, visa est, quae, Candide, Nympha? dic, age, nam coeptum certamen inutile nobis; utilior sermo de religione tenendus.

C. Galbula qui solitus pecudes in pascua tecum ducere te satis hoc potuit docuisse quod optas.

$A$. Plura quidem Polluce super narrata, sed ipsam 
nec docuit Nympham nec me quaesisse recordor. nunc subiit mentem, cum religionis oborta est mentio, et illarum visa est mihi maxima laudum.

C. Non erat illa Dryas neque Libethris nec Oreas; venerat e caelo Superum Regina, Tonantis Mater, anhelanti pacem latura iuventae. huic Tethys, huic alma Ceres famulantur, et ipse Aeolus aequoreis ventos qui frenat in antris. hanc Deus astrorum flammas super atque volantes Solis equos, supra fulgentem Cassiopeiam extulit et sacram bis seno sidere frontem cirxit et adiecit subter vestigia lunam.

$A$. Candide, mira canis nullis pastoribus umquam cognita. quid Tethys? quid fulgens Cassiopeia? Aeolus aequoreis ventos quis frenat in antris? qui sunt Solis equi? magna atque ignota recenses.

$C$. Sidera sunt partim, partim sunt numina prisca. omnia quae Pollux mihi cum narrasset, in aedem duxit et 'ista sacer paries,' ait, 'omnia monstrat.' pictus erat paries signis et imagine multa. omnia non memini (mens est mihi debilis) ista vix tenui dum saepe animo volvo atque revolvo; saepe recordari medicamine fortius omni. ista potest nigro depellere nubila caelo, ista potest siccis fluvios dare frugibus imbres. cum volet, ista novos duris emittere campis, .cum volet, emissos poterit restringere fontes. qui modo sunt steriles et nudi gramine campi, si volet, in pingues poterit convertere glaebas. frigida Saturni cum sidera suscipit atro Scorpius hospitio, non auferet hordea grando nec domus ardebit (nam tunc haec omnia caelum dicitur iratis in terram effundere $a b$ astris) si volet, haec nobis custodiet omnia virgo. si favet haec nobis, complebunt horrea messes adicietque gregi semper fetura geméllos. .si pecus infelix erit et sine vellere, solo ipsa potest nutu dare lac, dare vellera et agnos et curare greges omnemque avertere morbum. nil opus est modo Pana sequi neque cetera ruris numina quae veteres frustra coluisse feruntur. 
vidi ego circum aram Nymphae pendere capellas, plaustra, boves et oves. hic Ianni vidimus hircum et memini inscriptam versu hoc legisse tabellam: VOTUM PRO SALVO IANNUS BREVE REDDIDIT HIRCO.

Dumque ea perlegerem, Pollux haec carmina supplex ante aram genibus positis in marmore dixit:

- $O$ Dea, quae servas urbes et rura, precamur ne Padus exundet nec strix nocturna per umbras hauriat infantes nec eant per compita larvae. Diva, fave agricolis ; talpas occide malignam aggeribus pestem; gelidis sata laeta pruinis, quando bruma venit, conspergere, Diva, memento, ne tineae erodent anno frumenta sequenti.

a Boreae flatu pingues defende mariscas,

a gruis ore fabas et ab ansere farra palustri,

a serpente boves, a vulpe et fure cohortem,

a brucho erucas, a bruma et grandine vites,

a vi et fraude lupi pecus, a robigine fruges, a rabie catulos, a flamma et fulmine villas,

a murum insidiis petasonem, a milite pernas, a campe et pigris-pigris' (heu cetera nescit mens oblita sequi. numerus me in verba reduxit saepius; ad numerum rediens oblivia forsan mente abigam. retrogradior numerumque recurro) 'a murum insidiis petasonem, a milite pernas, a campe et pigris virides limacibus hortos' (Alphe, viden quae vis numeri? iam cetera cerno) 'a tonitru reboante cados, a frigore fetas, a gravibus vitulos oestris, a gutture porcos anginoso, operas pubes ne rustica perdat. adsis, o Dea, nec laedant examina fuci neu milium furentur aves neu vellera sentes sucida neu lappas apprendat lana sequentes. Diva gubernatrix hominum, custodia vatum, Diva laborantum requies, medicina dolentum et tutela gregum, nostris, precor, annue votis.'

Talibus orabat Pollux; ego postibus haerens in baculum pede porrecto recitata notabam altius ac memori condebam singula mente.

$A$. Candide, Polluci pro sollicitudine tanta, pro precis officio, pro religione putasne 
dandum aliquid nobis? pietate peculia crescunt.

C. Quid ni aliquid dandum est? opus est persolvere crates.

$A$. Rusticus es, 'crates' etenim pro 'gratibus' inquis.

C. 'Crates' et 'grates' parvo discrimine distant. 160 dandum aliquid; neu bis detur, sine Pascha reverti, quando sacerdotes commissa piacula solvunt.

$A$. Quid dabimus? vituli gravis est iactura. vel agnum vel leporem? pietas etiam laudabilis anser.

$C$. Dona docet tempus. lepores brumalia dona, quando nive hiberna currendi erepta facultas; anser ad autumni finem nonasçue Kalendas pertinet ; aestatis coryli, nova poma, racemi, munera; lactentes haedi sunt veris et agni. tunc si de cordis aliquem conspexeris aegrum ac tenuem qui nec vendi nec vivere possit (munus erit sollemne satis) donabimus angum.

Ipse mihi, cum iam regredi post prandia vellem, carmina de Nymphae sollemnilus eruta fastis tradidit et dixit, "si quando gravabere curis, haec cane; pro mentis medicamine carmen halseto:

"Quando Molorchaeo 'l'itan descendit ab) astro pronus et Astraeae iam limina virginis intrat, Virgine laetetur pubes et cana senectus; transiit ad Superos et Olympica regna petivit.

Ogdoas ut toto iam tertia fluxerit orle, festa dies iterum; natalia Virginis aras ignibus illustrant, offert nova liba sacerdos. Libra redit noctes properans aequare diebus, exsultat Picenus ager, vehit Hadria puppes Illyricas et Chaonias, cum mercibus adsunt Tusci, Umbri, Veneti, Siculi ; Lauretica templa cum donis turmatim adeunt votisque solutis in sublime iugum laeti ad commercia tendunt.

Et cum Thessalicas cursu breviore sagittas sol subit et frigent urentibus arva pruinis, clausa gynaecei sacris penetralibus hausit corde Deum toto proprios oblita parentes.

Et cum semiferi fugiens Chironis ab arcu languet ad hiberni glacialia limina Capri, induat ormatas et mas et fomina vestes laetitiaque diem celebrent yuo semine sucro 
coniugis annosus gravidam pater imbuit alvum. illa dies etenim sanctae primordia Nymphae fecit et in nostras vetuit descendere sordes.

Cum volat imbrifera lampas Phoelea sub urna ad vernos reditura dies, iam proxima veri, ite, nurus omnes, sacros altaribus ignes, tura focis, faculas manibus date, ducite pompam; attulit in templum nova dona puerpera virgo.

Quando gregis Princeps aurato vellere fulgens incipiet Zephyris aperire tepentibus annum et dare maiores luci quam noctibus horas, aliger occultam redeat Paranymphus in aedem et nova miranti referat mandata puellae. festa dies 'Tuscis populos de collibus omnes cogit et Arnicolas vocat ad Florentia templa. tum quoque sed tenui virgo prius intervallo mupsit, et hace teneris lux est celebranda puellis.

(Quando sub extrema (ancri testudine Phoebus volvitur et revehit vicina Canicula morlos, ture piam celebrate diem ; redit hospita mater in proprios a matre lares. altaria circum primitias Cereris geminae suspendite matri."'

Ista dedit Pollux vigilans quae in montibus olim fecerat ad pecudum caulas, dum nocte serena militiam caeli sparsosque examinat ignes. his quoque plura dedit; sed carmina plura referri non sinit extremum deponens vespera solem. 


\section{ECLOGA IX, FALCO, \\ DE MORIBUS CURIAE ROMANAE, POST RELIGIONIS INGRESSUM.}

FaUSTULUS. CANDIDUS.

F. Candide, quo casu patriis procul actus ab oris haec in rura venis? hic pascua nulla nec amnes nec liquidi fontes nec ovilia tuta nec umbrae, et tamen assiduos gregis haec pascuntur in usus.

$C$. Faustule, me noster Corydon (qui plurima quondam his armenta locis habuit magnamque peculi congeriem fecit) pecori me credere adegit esse salutares istis in montibus herbas; at postquam segnes agros et inertia saxa vidimus et siccis arentem fontibus undam, paenituit longacque viae patriaeque relictae.

$F$. Postquam te incolumem saltus intrare Latinos contigit, antiqui potes haec mea tecta subire iure sodalitii. sunt hic mihi pauperis agri iugera pauca meae vix sufficientia vitae; quidquid id est commune puta. tibi forsitan ulla prospera sors aderit; fortuna simillima vento est. cariceae succede casae, dum praeterit aestus, dum grex in gelida procumbens ruminat umbra. pone pedum, discumbe parum, recreabere potu ; potu opus est, potu iste gravis compescitur aestus. pocula prende; fluet melius post pocula sermo.

$C$. Pocula quis tanta demens aestate recuset?

$F$. Vina sitim minuunt animique doloribus obstant, vina ut amicitias vires ita corporis augent.

$C$. Haec parit ora bonos (si patria vina) racemos.

$F$. Funde iterum; potare semel gustare, secundus colluit os potus, calefacta refrigerat ora tertius, arma siti bellumque indicere quartus aggreditur, quintus pugnat, victoria sexti est, septimus (Oenophili senis haec doctrina) triumphat.

$C$. Res est consiliis secura fidelibus uti, utile doctrinis praebere senilibus aures. 
victa sitis, mens aegra manet curaeque supersunt.

F. Ut sedata sitis, sic mens sedabitur aegra. funde merum, bibe ; cardiaco medicina dolori haec, utitur ad curas isto medicamine Roma.

$C$. Omne opus atque labor vult intervalla; quiescat obba parum, contra muscas impone tabellam. non madet imbre dies nec habet nox umida rorem crescere nec duris possunt in cotibus herbae. importuna fames, labor improbus, aëris ardor confecere gregem macie; vix debile corpus spiritus aeger agit, vacua cute porrigit ossa clunis et exilis cava contrahit ilia venter. hic aries qui fronte lupos cornuque petebat nunc ove debilior pavidoque fugacior agno est. haec mihi (sed nimium me ardentia vota ferebant) omnia divino praedixerat omine cornix. vix egressus eram limen, cum tristia portans auguria a dextra venit tegetisque sinistrae culmine consedit pressoque minaciter ore vociferans iter auspicio prohibebat aperto. heu pecus infelix, quod lacte et prole solebas affluere, in nostris licuit dum pascere campis, gramina dum quaeris, suci plus perdis eundo quam referas pastu. simul hic tabescimus ambo, tu tenui victu, curis ego victus amaris.

$F$. O nostrae regionis opes, o florida prata, o campi virides, o pascua laeta feraxque et numquam sine fruge solum, currentia passim flumina per villas, rivi per rura, per hortos. hinc pecus, hinc agri pingues; sub sidere Cancri, cum tritura sonat passim, cum Iulius ardet, arva virent, textae lento de vimine saepes poma ferunt, redolent ipsis in vepribus herbae.

$C$. O nemorum dulces umbrae mollesque susurri, quos tecum memini gelidis carpsisse sub umbris turturis ad gemitus, ad hirundinis ac philomenae carmina, cum primis resonant arbusta cicadis. aura strepens foliis nemorum veniebat ab Euro et bacata super tendebat bracchia cornus. ipse solo recubans pecudes gestire videbam atque alacres teneris luctari cornibus agnos. 
post somnos per gramen humi nunc ore supino aut flatu implebam calamos aut voce canebam, pectore nunc prono rutilantia fraga legebam.

$F$. Vivere tum felix poteras dicique beatus; sed bona (quod nondum fueras expertus acerbam)

vilis erat tibi teque ideo, fortuna reliquit. quando iterum veniet (veniet si forsitan umquam) sicut capreolis sursum nitentibus haerent stipitibus vites stringuntque tenaciter ulmos, sic illam tu prende manu neu desere prensam. it, redit, effigiem mutat nec imagine constat par lamiis quas nocte ferunt errare per umbras. mobilis ut facies, ita mens; deludere gaudens quod dederat tollit; pensi nihil, omnia casu; qui nimium metuunt sapiuntve repellit et odit.

$C$. Delicias patrii quotiens reminiscimur agri, ferre tot aerumnas animo non possumus aequo. sed quo mente feror? casu afflictatus acerbo unde magis crucier felicia tempora volvo. Maius adest: florent vites humilesque genistae, iam spicata seges, malus iam Punica multo flore rubet, redolent saepes albente sabuco in patria, per rura Padi, per pascua Minci ; hic vero necdum incipiunt pubescere montes. quod si vere solum torpet, quid frigora lrumae solstitiumque feret, gelidis cum terra pruinis albicat et rapirlo cum caelum incanduit aestu? sunt tamen hic armenta quilus cutis uvida, cervix non signata iugis, gemino frons ardua cornu Juxuriansque toris pectus; nisi pabula carpant, non erit hac tanta umectum pinguedine corpus.

$F$. Haec armenta quibus caput a tellure levatur altius et cui sunt longa internodia crurum cuncta vorant, herbas primum, mox ore supino arboreas frondes summaeque cacumina silvae; hoc imhelle pecus quod humi nascentia tantum gramina decerpit vacuis ieiunat in arvis.

$C$. Quid verbis opus est? cunctis animantibus una est condicio: semper maiora minoribus obsunt. agna lupo. mites aquilis sunt praeda columbae, innocuos delphin venatur in aequore pisces, 
unde fit hoc? (certe res prodigiosa videtur) haec loca, si procul hinc videas e rupibus altis, pingue solum et multo vestitum gramine dicas; quo magis appropias tanto magis omnia sordent.

F. Hoc est Roma viris avibus quod noctua: trunco insidet et tamquam volucrum regina superbis nutibus a longe plebem vocat. inscia fraudis turba coit, grandes oculos mirantur et aures, turpe caput rostrique minacis acumen aduncum; dumque super virgulta agili levitate feruntur nunc huc, nunc illuc, aliis vestigia filum illaqueat, retinent alias lita vimina visco, praedaque sunt omnes veribus torrenda salignis.

$C$. $\mathrm{O}$ bellum hoc; poterit dici nihil aptius umquam. sed procul en coluber tortos in pulvere gressus flectit et exsertis sitiens ferit aëra linguis.

$F$. Candide, quae moneo memori sub pectore serva. quando inter silvas graderis, defende galero lumina, namque rubi praetendunt spicula longis dentibus et curvus discerpit pallia mucro. nec depone pedum multaque armare memento cote sinum, ne te subito novus opprimat hostis. et perone pedem tegito; spineta colubris plena hominum vitae morsu insidiantur amaro, et nunc longa dies aestu facit acre venenum. mille lupi, totidem vulpes in vallibus istis lustra.tenent et, quod dirum ac mirabile dictu est, ipse homines (huius tanta est violentia caeli) saepe lupi effigiem moresulue assumere vidi inque suum saevire gregem multaque madere caede sui pecoris; factum vicinia ridet nec scelus exhorret nec talibus obviat ausis. saepe etiam miris apparent monstra figuris quae tellus affecta malis influxibus edit; saepe canes tantam in rabiem vertuntur, ut ipsos vincant caede lupos, et qui tutela fuerunt hostiles ineunt animos et ovilia mactant. fama est Aegyptum coluisse animalia quaedam et pro numinibus multas habuisse ferarum; ista superstitio minor est quam nostra. ferarum hic aras habet omne genus, contraria certe 
naturae res atque Deo qui dicitur olim praeposuisse hominem cunctis animantibus unum. saepe etiam morbosa aestas et pestifer annus ingruit et passim languens pecus omne per arva 160 sternitur ; exstinctae dum balat ad ubera matris, agnus obit, moritur duro sub pondere taurus. nec modus est morbo, non est medicina veneno, sed vicina domus vicino a limine mortem haurit et assidue sumunt contagia vires. ista feras raro pestis rapit, utile semper fert pecus; exstinctas caulas epulantur atroci dente lupi nostraque ferae iactura opulescunt.

$C$. Heu, heu quam praeceps miserum me insania traxit; credere fallaci gravis est dementia famae. Romuleos colles, Tiberim Romanaque tecta audieram et studio mens est accensa videndi ducendique bonis in tot praestantibus aevum. accessi cum parte gregis, tentoria demens, totum paene larem cum pastoralibus armis trans iuga summa tuli, mulctraria, cymbia, aëna et cacabos et quo formatur caseus orbem fagineum; impensam atque operas amisimus omnes. quid faciam? quo me vertam? sperata negantur pabula; tot casus, tot ubique pericula. cogor in veteres remeare casas et coeptá fateri consiliis egressa malis iterumque per aestus et montana pati longos per saxa labores. heu pecus infelix, o laevo sidere pastor huc avecte. fuit multo praestantius istud ignorasse solum patrioque in limine tutos consumpsisse dies, gelidis senuisse sub antris atque Padi circum ripas Athesisve per agros aut ubi per virides campos et pascua nota Mincius it vel qua vitreo natat Abdua cursu consedisse, gregem pavisse salubribus herbis.

$F$. Te tua credulitas, et me mea fallit in horas. vidi ego supremae qui prosperitatis habebant culmina, dum laudata petunt, cecidisse nec umquam emersisse malis ; facit experientia cautos. hi prius explorant et non laudata sequuntur omnia; laude carent quae sunt meliora. fuerunt 
(non nego) quae famam retinent ac nomina servant (cuncta suis pollent vicibus) Luna, Hadria, Troia, Salvia (quas nobis memorabat saepius Umber) nomine sunt solo, delevit cetera tempus.

si minor est patriae forsan modo gloria nostrae, res tamen est melior. laudatae gloria Romae quanta sit in toto non est qui nesciat orbe; fama quidem manet, utilitas antiqua recessit. - illi prisca quibus maduerunt pascua fontes nunc umore carent, venis aqua defuit haustis, nulla pluit nubes, Tiberis non irrigat agros, tempus aquaeductus veteres contrivit et arcus et castella ruunt ; procul hinc, procul ite, capellae. hic ieiuna fames et languida regnat egestas.

Hic tamen (ut fama est et nos quoque vidimus ipsi) pastor adest quadam ducens ex alite nomen, lanigeri pecoris dives, ditissimus agri, carmine qui priscos vates atque Orphea vincat, Orphea qui traxit silvas et saxa canendo. hic alios omni tantum virtute Latinos exsuperat quantum Tiberim Padus, Abdua Macram, lenta salix iuncum, tribulos rosa, populus algam. credimus hunc illi similem cui Tityrus olim

bis senos fumare dies altaria fecit.

hic ovium custos ipso vigilantior Argo

Daphnide nec solum sed eo qui dicitur olim Admeti pavisse greges per Thessala rura doctior, omne pecus Solymi curare magistri dignus et antiquo dignus succedere patri qui fuit Assyrii pecoris post retia pastor. iste potest servare gregem, depellere morbos, umectare solum, dare pascua, solvere fontes, conciliare Iovem, fures arcere luposque.

si favet iste, mane. quod si negat iste favorem, Candide, coge pecus melioraque pascua quaere. 


\section{ECLOGA X, BEMBUS,}

\section{DE FRATRUM OBSERVANTIUM ET NON OBSERVANTIUM CONTROVERSIA, POST RELIGIONIS INGRESSUM.}

CANDIDUS. BEMBUS. BATRACHUS. MYRMIX.

C. Maxima pastores agitat discordia, Bembe, qui Solymos colles Galilaeaque rura colebant; Batrachus hinc, Myrmix illinc certare parati iudice te paucis, si non audire recusas et nisi te revocant maiora negotia, dicent. tu pater es vatum, tu scis componere lites iurgiaque et blandis convicia tollere verbis; te quoque Pierios fama est potasse liquores et vidisse deas quibus est custodia sacri fontis et Eurotae campos ac Phocidis arva, ipse ubi fronde sua tibi tempora cinxit Apollo, dona dedit citharam, nervos et eburnea plectra.

$B e$. Dicite, quandoquidem tepidos admovit ad ignes nos hiberna dies, dum non sinit ire per agros bruma gregem, flatu Boreas dum saevit acuto, dum riget omne solum, tectis dum plurima pendet stiria, dum torpent sub aquis glacialibus amnes; otia damnantur quae nulla negotia tractant.

$M$. Pastores, genus infelix, aestate vagamur pro grege solliciti, sed cum nos frigidus imber continet in stabulis, lites et iurgia surgunt.

$B a$. Qui veteres audent ritus mutare suoque arbitrio et nullis ducunt sub legibus aevum, hi sunt, o Myrmix, qui bella domestica gignunt.

$B e$. De veteri ritu, de consuetudine patrum rixa agitur vobis? leges moresque parentum, Batrache, dic. dic, cur nostrum venistis in orbem ex Phoenice solo? nos pascua vidimus illa, vidimus herbosos felici uligine campos. vertice Carmeli vitreis uberrimus undis

fons cadit et rauco densum nemus irrigat amne. vidimus et Iordanis aquas, ubi maximus olim pastor oves mergens scabiem resecavit avitam. 
amnis hic a Libano veniens Galilaea per arva transit et ampla lacu consurgit in aequora magno; unda coit rursum, rursum mare fundit apertum, urbs ubi Romani de nomine dicta Tiberi; unda coit rursum, tandem Iericunte relicta intrat in infames Asphalti gurgitis undas. hinc satis est nos oram omnem vidisse probatum; dicite, et hinc tandem vestras demergite lites.

M. Batrachus audaci semper sese ingerit ore et mihi se praefert magno temerarius ausu.

$B a$. Non ego me ingessi, processi a iudice iussus.

$B e$. Pone pedum, Myrmix, et tu quoque, Batrache; non est orandum armatis manilus, sed mentibus aequis. Batrache, dic ; Myrmix, animi compesce furorem interea, ut.venias magis ad responsa paratus. qui furit insanit; qui vero insanit amaro impatiens animo nec corda nec ora gubernat; quidqui' ait vanum est, quidquid molitur ineptum.

$B a$. Bembe, geinus nostrum generisque exordia dicam. venimus Assyriis (ut Candidus inquit) ab oris. est pater Elias nobis qui sustulit armis pastorum genus omne malum, qui traxit Olympo flammigeros ignes, qui ascendit in aethera curru.

$B e$. Nobile et antiquum genus hoc, et clara propago. .

$B a$. Pastores alii quotquot per rura vagantur omnia sunt rivi nostris a fontibus orti ; nos dedimus leges, pascendi ostendimus artem. quo magis hi peccant qui, cum sint ordine primi, primatum amittunt studia inconsulta sequendo. nos radix, alii rami; sed nos quoque rami a veteri radice patrum ian aetate caduci. tradidit Elias certam pastoribus artem qua curare greges, qua noxia pabula fas est discere et occultos imbres ventosque latentes quive salutaris foret et qui pestifer annus; signa dedit, nihil omisit quod ovilia tangat. sed fons ille fluens Carmeli e rupibus altis tam nitidus quondam, tam dulci limpidus unda, tramite mutato (patet id) modo currit in Austrum. sed prius (extat adhuc vetus alveus) ibat ad ortum. hi cursus fecere novos, liquere priores 
quos dederat rivo veterum prudentia patrum.

$M$. Quid tibi, sive novo currat seu tramite prisco, dummodo fecundis umectet pascua lymphis? et quid de caeli quereris regione? per Austrum solis iter, melior vitis quae respicit Austrum, et melior legitur Libycis de collibus uva.

$B a$. Est melior taxus Boream quae respicit; ergo in Boream melius poterat decurrere rivus. pastor es, et cura pecoris male sane relicta sermonem de vite facis quasi legibus isdem grex et vitis eant, nec quod discrimen in undis gramineque et ventis nosti et quam noxius Auster sit pecori; disce a Roma si noxius $A$ uster. cur Mutinensis agri pecudes sunt vellere fusco? cur Clitumnus habet niveas? cur Mantua molli lanitio excellit Veronaque proxima Manto? unde haec multiplici rerum variantia forma? non aliunde nisi a caelis, a gramine et unda.

$B e$. Candide, utrumque pedum procul hinc (rogo) protinus aufer;

inter eos hodie video bellum acre futurum. clam cape et auferto; subter sarmenta reconde.

$B a$. Bembe, mihi tecum sermo est. dum viximus una, dum commune pecus nobis fuit, heu mihi quantum dedecus, heu quot sunt pecudes incommoda passae. nec mersare gregem fluvio nee vellera certis temporibus (sicut mos est) tondere licebat. 100 nudabant spineta pecus. nudata secabant terga rubi; scabie cutis aspera, tabidus umor pestis, et in totum serpebant ulcera corpus. multum igitur refert pecudes quae pabula carpant, flumina quae potent et qua regione morentur.

Dic mihi, dic, Myrmix, priscum cur lana colorem perdidit? haec gregilus quidnam nova vellera fecit? cur pecus est nigrum quod erat melioribus annis clarum? immutarunt mutati vellera mores.

Bembe, ad te redeo. paucis absolvere nitar, sed, quo digna omni tua sit sententia laude, vera loquar. tu iura tenes, ego facta docebo; iudicium reddit verum enarratio vera. his animadrersis aegre tot damna ferentes 
venimus ad fontem, rivumque a vertice summo scrutari mihi cura fuit; tu, provide Myrmix, . interea nidos avium vel dorcada parvam venabare tuae quae dona darentur amatae.

$M$. Bembe, vides ut aperta in me convicia torquet? auguror, ista manu lis est, non ore, agitanda ; mos mihi, non lingua, maledicta refellere dextra.

$C$. Batrache, ne verum taceam, linguosior aequo es; iurgia bilem acuunt, convicia pectus acerbant. non tibi cum puero res est, nec homuncio Myrmix; . res male tuta viros lingua irritare proterva.

$B a$. Da veniam, Myrmix; ' amitam' proferre volenti nescio quis mihi misit in os malus error 'amatam.'

$M$. Do veniam; cave ne rursum me voce lacessas.

$B a$. Alveus excelsa saliens de rupe lacunam foderat et clausis ripas aequaverat undis; gurges erat textu silvarum umbrosus opaco densaque saepierant tristem spineta lacunam. mille venenorum species in gurgite vidi, mille secus ripas in opaco margine, mille per nemus ad lymphas sinuoso serpere gressu. obstupui, et rapido rediens ad ovilia cursu incipio paleas furca versare tricorni. ecce caput tollit coluber linguaque trisulca sibilat, inflantur fauces, nepa livida tendit bracchia, ventrosus profert vestigia bufo, vipera per stipulam gradiens strepit. 'o loca,' dixi, 'non pecori tantum verum et pastoribus ipsis noxia.' mox grege diviso de sedibus illis pascua quaesitum tristis meliora recessi. perque iter antiquum fontis nova flumina duxi in campos ubi prima suos Aurora colores explicat et croceos Phoebi redeuntis ad ortus. hic mihi fecundae pecudes, hic pascua laeta et sine labe liquor, dulces sine crimine lymphae. haec loca primaevi sunt quae coluere parentes; signa casae superant, puteus cariosaque ligna fixa solo seiuncta pedum discrimine septem et focus et lacera quae cingitur area saepe.

$M$. Cura viris levibus rerum solet esse novarum; propterea certe nova pascua quaeris et amnes 
fingis inauditos et vis novus auctor haberi.

$B a$. Cura viris gravibus rerum solet esse suarum; propterea, Myrmix, nimis a gravitate recedis. haec novitas non est novitas, sed vera vetustas. religio et pietas patrum instaurata resurgit 160 quam tua corrupit levitas et nota tuorum segnities. igitur si quis labentia tecta crigat et sterilem qui mansuefecerit agrum iudice te damnandus erit? non ponitur arbor altera, sed veteri inseritur bona virgula trunco; segne prius lignum nostro fit fertile cultu.

$M$. Quamvis pingue tuo pecori sit gramen et unda defaecata, tamen multae cum matribus agnae interiere; lupi et pastae meminere volucres.

$B a$. Hae (fateor) quae dira tuae contagia pestis accepere. etiam procul aspicientibus obsunt; tantum virus incst, vestri vis tantil veneni. propterea nagis atque magis discedere semper est animus. patitur pecus hace incommoda nostrum sola, quod in vastam nondum discessit eremum nec satis a vobis procul in deserta recessit.

$M$. Batrache, de gregibus mentiris plurima nostris. certe alienarum tibi cura superflua rerum, et temere assumis partes censoris iniqui. cur mihi qui pasco cuium pecus ista tueri non licuit? solisne dom'ss mea cognita vobis?

$B a$. Aethiopes una quoniam nigredine sordent, ille color nulli vitio datur; omnibus idem vultus et alterius si quis reprenderet ora, et sua damnaret. pecori pecorisque magistris faex eadem, scabies eadem, cutis et color idem.

$B e$. Parcite ; iam satis est lis intellecta diesque inclinata cadit, iam post iuga summa ruit sol. audite, o magni generis longaeva propago lite super vestra quae sit sententia nostra.

M. Batrache, me audaci totiens sermone lacessis.

$B a$. Non ego, sed non aequa magis te causa lacessit iudiciumque timet sibi mens male conscia iustum.

C. Quando inimicitias tempus deponere, rursum vestra novas lites vecordia suscitat. ergo perpetuis haec rixa odiis aeterna manebit? 
quae vos debilitas capitis, quae insania vexat?

non pudet his uti tanto sub iudice nugis?

ergo animis audite aequis odiisque sepultis

ultima doctiloqui quae sit sententia Bembi.

200

- Be. Ferte per antiquos patrum vestigia gressus

et veteres servate vias. revocate vagantes

per valles et saxa greges, per lustra ferarum.

figite in antiquis iterum magalia campis. 
-

-. 


\section{NOTES}

\section{THE DEDICATORY EPISTLE.}

Thx Paride Ceresara to whom the revised Eclogwes were dedicated was a nobleman of Mantua, distinguished for his great wealth and wide learning. In one of the novels of Bandello (ii. 5) he is called 'nobilissimo $e$ in ogni sorta di lettere dottissimo.' He translated the Aulularia for the Bishop Lodovico Gonzaga, and perhaps also a Greek comedy. And he had some knowledge of Hebrew. In his later years he was interested in astrology and in the 'occult sciences'; hence the mention of him by Luca Gaurico: 'erat facie et barbitio rufus, procerae staturae, sed proportionatus; ex Iove in horoscopo cum Marte ditissimus et locuplex; habebat aedes regias; ingeniosus, legum professor, in litteris latinis et graccis eruditus. Quum senectutis limina fuit ingressus, incepit dare operam astrologiae.' He was born in 1466, and died in 1532. [Luzio-Renier, Giornale storico della letteratura italiana, xxxiv (1899), 86-88].

\section{ECLOGA I, FAUSTUS.}

\section{Antiguos repeti vult Fortunatus amores;} Obsequitur Faustus referens conubia lasta.*

At Fortunatus' request, Faustus repeats the story of his love, courtship, and marriage-the story of an honorable love and its happy ending. This eclogue (with various details added from the second, third, and fourth) is imitated in the first 'eglogue' of Francis Sabie's Pan's Pipe (1595).

1-2. Cp. Boccaccio, Ecl. vi. 81, ruminat omne pecus. The same phrase occurs in the Ecloga Theoduli, 248.

4. $\operatorname{modo}=n u n c$, as at ii. $151, \mathrm{v} .35$, viii. $102,114, \mathrm{ix} .202, \mathrm{x} .72$. So often in the Ecclesiastical Writers and in the Latin Bible: e. g., John, ix. 25, 'scio quia, caecus cum essem, modo video.'

9-10. Virg. Aen. i. $372 \cdot 3$, 0 dea, si prima repetens ab origine pergam, I et vacet annales nostrorum audire laborum;' Geor. iv. $285-6$, 'altius omnem | expediam prima repetens ab origine famam.'

* Ioannis Murmellii argumentum. 
11. Ovid, Met. xiii. 595, primisque sub annis.

12-13. Petrarch, Ecl. vi. 78-79," sedeo iaceoque supinus, I multa canens quae dictat Amor nec crastina curans.'

19. Virg. Ecl. ii. 36, 'disparibus septem compacta cicutis | fistula.'

22. Virg. Ecl. ii. 72, 'viminibus mollique paras detexere iunco;' Ib. $x$. 7I, 'fiscellam texit hibisco;' Geor. i. 266, 'texatur fiscina virga;' Nemes. Ecl. i. I, 'fiscella ... iunco / texitur.'

24. sortiri digitis: the ancient and modern game of 'mora'.

27-31. Cp. Virg. Geor. i. 381, 'e pastu decedens;' Aen. vii. 700, 'cum sese e pastu referunt;' Geor. iv. 5 I1-12, 'qualis populea maerens philomela sub umbra | amissos queritur fetus;' Stat. Theb. v. 601-3. "illa redit, querulaeque domus mirata quietem | iam stupet impendens advectosque horrida maesto | excutit ore cibos.' philomena : this form of the word was already familiar in Italian; cp. Petrarch, Sonn. 269, 'piagner Filomena.' Du Cange cites it from a Glossarium of the year 1348. hymennaeos: for the cadence, cp. Virg. Aen. vii. 555 ; x. 720 ; also, Mantuan, Ecl. vii. 133; viii. Io; ix. 69 ; ix. 168.

32-35. Cp. Stat. Theb. vi. 174-77, 'nunc vallem spoliata parens, nunc flumina questu, | nunc armenta movet vacuosque interrogat agros; | tunc piget ire domum, maestoque novissima campo | exit et oppositas impasta avertitur herbas;' Virg. Ecl. v. 26, 'nec graminis attigit herbam.' pallenti...umbra: cp. Virg. Geor. iii. 357. 'tum sol pallentes haud umquam discutit umliras' (where Conington translates, 'the wan shades of night').

38. Virg. Aen. i. 387 , auras | vitales carpis.

45. 'Nam et Venus paeta dicitur' (Ascensius). Cp. Francis Sabie's imitation, Pan's Pipe, i. 137-8, 'for where she squinted a little, | That did grace her, I thought.' Fontenelle was offended by the rustic realism of this passage; also, of Ecl. iv. 87-88.

48-5 I. Cp. Cic. C. $M$. xii. 42, 'impedit enim consilium voluptas, rationi inimica est, mentis (ut ita dicam) praestringit oculos.' credo... concitet... tollat: cp. viii. 44 , 'puto sidera tangant,' and perhaps also Mantuan's De Vita Beata, 'dicis Archimedem fecisse mundum; putasne fecerit nebulas? putasne aestatem, putasne solstitia et aequinoctia posuerit?' and Boccaccio, Ecl. xiv. 46-48, 'Silvi, quid dubitas? an credis Olympia patrem | ludat, et in lucem sese sine numine divum | praebeat?' St. Augustine could say, Conf. i. 14, 23. 'credo etiam Graecis pueris Vergilius ita sit, cum eum sic discere coguntur ut ego illum;' ix. 13, 36, 'et credo iam feceris quod te rogo.' In a letter to his friend Refrigerio. Aug. 12, 1478, Mantuan wrote: 'Audivistine Benedicti Morandi viri praestantissimi obitum? credo audiveris: et puto quem viventem tanto charitatis affectu complectebaris mortuum defieveris' (MS. copy in the Library of the University of Bologna).

58. Cp. Virg. Aen. i. 239, fatis contraria fata.

59. catus: the classical name is feles. The name cattus (cp. It. gatto and late Gr. kártos) appears first about 350 A. D. For the history of the animal, see Mayor's note on Juvenal, xv. $i$, and O. Keller, Die antik' Tierwelt, Leipzig, 1909, p. 74. Mantuan's spelling reflects the popular etymology of his day; cp. Perotti's 
Cornucopiac, 'est igitur felis quem vulgo catum nominamus, nec meo quidem indicio inepte. veteres enim catum astutum dicebant et quod nos in praesentia cautum; a quo Catones primo volunt appellatos' (Venice ed., 1494, fol. 108).

61. Fortunatus' comment explains the mother's lack of sympathy. The expression was proverbial; $\mathrm{cp}$. the words of Aeneas Silvius (in a letter to Joannes Urunt, 1446), 'nam ta me pleno stomacho reris ieiunium commendare.' St. Jerome, $E p$. 58. 2, has 'plenus venter facile de ieiuniis disputat.'

62. This line is borrowed in the Cambridge Latin play Laelin (c. 1595), i. 3, 176-7, 'quas nulla premit sitis / sunt illae asperiores semper sitientibus' (ed. G. C. Moore Smith, Cambridge, 1910).

64. albebant. Cp. Juvencus, ii. 313, albentes cernite campos; John, iv. 35, quia albae sunt iam ad messem.

74. Cp. Virg. Aen. vii. 227, plaga solis iniqui.

83. Virg. Aen. ix. 614, fulgenti murice.

97. Virg. Ecl. ix. 24, et potum pastas age; Ib. ii. 30, gregem viridi compellere hibisco.

98. Virg. Ecl. v. 47, saliente sitim restinguere rivo.

103. Cp. Mantuan's Alfonsus, Bk. i (Bologna ed., 1502, fol. 251), 'lumina demisso in cilium claudebat amicta.' de sub: 'from under.' For such double prepositions, see Rönsch, Itala und Vulgata, pp. 234-5, 475. In some later editions the line is rewritten: demissis aliunde sui velaminis oris.

106. operi ... intendens. Cp. Minuc. Fel. Oct. vii. 5, intende templis; Augustine, Conf. ii. 10, 18, nolo in eam intendere; Ib. xi. 2. 3, intende orationi meae; Psa. 54. 2, intende mihi.

113. Virg. Ecl. x. 49, 'ah tibi ne teneras glacies secet aspera plantas.'

115-6. Cp. Tibullus, ii. 3. 79-80, 'ducite: ad imperium dominae sulcabimus agros: | non ego me vinclis verberibusque nego ;' Ovid, $H$ er. vi. 97, 'scilicet ut tauros, ita te iuga ferre coegit;' Palingenius, Zodiacus Vitae, v. 444, ' fert placida cervice iugum.'

116. bovis instar. $\mathrm{Cp}$. ii. $7 \mathrm{I}$, bovis instar; vi:. 15, instar ovis; Ov. Met. iv. 135, exhorruit aequoris instar.

120. cottìdie. For Mantuan's scansion, compare one of his Epigrammata ad Falconem (on the death of Filippo Baveria), 'cottidie querimur, cottidie rapimur.'

121 . in nonam ...horam. See note on line 148 .

138. Cp. Ov. Met. ix. 761 , mediis sitiemus in undis.

142. rullam: 'instrumentum ferreum quo vomis detergetur' (Da Cange). Perotti, Corn., 'rulla significat instrumentum ferreum stimulo rusticorum additum ad vomerem detergendum: Plin. $\langle$ xviii. 49. 179 $\rangle$ purget vomerem subinde stimulus cuspidatus rulla.' The modern texts of Pliny have rallo. deerant... deerat ... deeram : synizesis, as in Virg. Geor. ii. 200, 233.

148. semel = 'aliquando, Gall. Une fois, un jour' (Du Cange, who quotes an example from a document of the year 1300). Mantuan's use of semel was criticized by his contemporaries, and defended by his brother Tolomeo: "in quo vult innuere id non aliquando simpliciter sed semel, hoc est non pluries, accidisse. ast hi valgariter loqui omnia consueti magis ad consuetudinem vulgi quam ad poetae 
sensum respexerunt. sed fingamus eos verum dicere et semel pro aliquando illic poni; si recte intelligerent, id non coarguerent. locus enim et tempus multa excusant quae alias essent digna redargui. locus ergo ille potuit illis, immo et debuit plene satisfacere, id enim est in Bucolicis dictum, ubi ridentur mores rusticorum, et Minerva pastoralis praesentatur. ibi etiam rusticus quidam Crates pro grates g. m. c. versa fabulatur $\langle$ viii. 158〉, et ad imitandum pro ridiculo villicos Pollux pro Paulus $\langle$ vii. I $\rangle$, Harculus pro Hercules

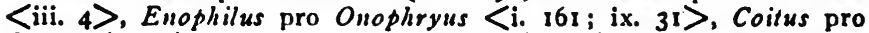
Godio $\langle$ ii. 37$\rangle$, hora nona pro meridie $\langle$ i. 121$\rangle$, et huius modi alia de industria ponuntur, non casu vel inscitia: ut fortasse isti criminantur' (Apologia contra detrahentes operibus B. M., Lyons ed., 1516, fol. Dd, ii).

154-55. Cp. Mantuan's De Sacris Diebus (of St. Urban's Day, May 25), 'musca volans noctu, dicunt lampyrida Grai, I nunc latet astrictis, nunc lucet hiantibus alis, | . . iam spicata Ceres;' Perotti, Corn., 'cicendula a Graecis lampyris dicta . . nunc pennarum hiatu refulgens, nunc conipressu obumbrata.'

156. Cp. Ov. Met. ix. 759, venit erce optabile tempus, | luxque ingalis adest.

159. gemina...luce: 'solis et taedarum' (Ascensius). Rather, it was a two days feast.

161. Oenophilus. See note on line 148.

163. Ovid, Met. xii. 158, multifori delectat tibia buxi.

167. multotiens: 'satis humile adverbium quo idonei abstinere dicuntur' (Asc.).

170. Cp. Catullus, 62. 3, iam pinguis linquere mensas.

173. Cp. Virg. Geor. iii. 66, 'optima quaeque dies miseris mortalibus aevi | prima fugit;' Plin. $E p$. viii. 14. 10, 'tanto brevius omne quanto felicius tempus.'

175. subintrat: for the transitive use, cp. Anthol. ii. p. 402 Burm., 'forte subintrarunt unica tecta simul.' The intransitive use is common in the Vulgate.

176. taxemur: a post-Augustan word.

\section{ECLOGA II, FORTUNATUS.}

Quae Padus exundans tulerit dispendia primum, Insanum memorat mox Fortunatus Amyntam.

The speakers are the same as in the first Eclogue. Here (and in the third) Fortunatus discourses on the madness of unlawful love, or unlawful desire, and its unhappy issue.

1. Cp. Calpurn. Ecl. vi. I, 'serus ades, Lycida ;' Ib. vii. I, 'lentus ab urbe venis, Corydon; vicesima certe | nox fuit,' etc.

5. ómissa : cp. x. 69, omisit, and the poem Alfonsus, Bk. i (fol. 255), segniter omisit. The Mantua edition of 1498 doubles the $m-$. as it does in amisso, i. 32 ; amissi, ii. 89. Cp. Boccaccio, Ecl. xv. 86, nec lacrimas òmitto. 
8-9. Virg. Geor. i. 48I-3; 'proluit insano contorquens vertice silvas | fluviorum rex Eridanus, camposque per omnes | cum stabulis armenta tulit.' Tityrus means Virgil, as in Virgil's first Eclogue. So, too, in Calpurn. iv. 62; Nemes. ii. 84 ; Boccaccio, Ecl. i. 82-5, x. 66; Mantuan, $E c l$. iii. 174, v. 86, ix. 220. In Spenser's imitation of Mant. v. 86, he is called 'the Romish Tityrus' ( $S . C_{0}, x_{0}, 55$ ). He is mentioned here as the author of the Eclogues and Georgics.

12-13. Virg. Geor. i. 43, 'vere novo gelidus canis cum montibus umor Y liquitur;' Ib. i. 326, 'implentur . fossae et cava fumina crescunt.'

17. Ovid, Met. viii. 559, 'dum tenues capiat suus alveus nndas.'

18. Virg. Aen. i. 439, mirabile diclu.

19. lacus: not Benacus (as Ascensius thought), but the lake formed by the Mincio at Mantua. Cp. Mantuan's Vita Lodovici Morbioli, 'et senior vitreo Mantua cincta lacu;' also, Ecl. vi. 105, 'Mantous Amyntas.'

25. This line is quoted in Mantuan's Dialogus contra Detractores (Lyons ed., 1516, fol. c. ii).

28. Cp. Virg. $E c l$. iii. $55-57$, 'dicite, quandoquidem in molli consedimus herba, | et nunc omnis ager, nunc omnis parturit arbos, | nunc frondent silvae, nunc formosissimus annus;' Geor. ii. 328-30, 'avia tum resonant avibus virgulta canoris, / et Venerem certis repetunt armenta diebus; | parturit almus ager;' Lucr. i. 2, 'alma Venus' (so Aen. i. 618; Ov. $F$. iv. 90); Lucr. i. 9, 'nitet diffuso lumine caelum.'

35. Virg. Aen. i. 705, 'centum aliae totidemque pares aetate ministri.'

37. Coitum : Goïto. See note on i. 148.

41. Virg. Ecl. i. I, recubans sub tegmine fagi.

43. umbra. Cp. Virg. Ecl. ix. 42, 'lentae texunt umbracula vites.' 45-46. Cp. Virg. Geor. i. 92, 'rapidive potentia solis;' Ib. ii. 353. ' ubi hiulca siti findit Canis aestifer arva;' Tibull. i. 7.21 , 'arentes cum findit Sirius agros.' sciderat. In the Bologna edition of the collected poems, 1502, the passage is rewritten: messis erat: rapidi violentia solis adustos I prosciderat campos. Cp. Servius' comment on Virgil's abscidit, Aen. iii. 418: 'propter metrum ' $c i$ ' corripuit per poeticum morem.' philomena: for the spelling, see i. $27 \mathrm{n}$.

47-48. Cp. Virg. Ecl. v. 77 , 'dumque thymo pascentur apes, dum rore cicadae; ' Geor. i. 107, 'exustus ager morientibus aestuat herbis.'

49. intendit. Cp. i. 106, operi... intendens.

6o. sulphuris arcem: Solferino.

6r. longis... prospectibus. Cp. viii. 4-5, longe / prospicio; Virg. Aen. iii. 206, aperire procul montes.

63. sacra... Petro: the day of S. Pietro in Vincoli (Aug. 1).

69. Virg. Geor. iii. 431, ingluviem :...explet.

71. bovis instar. $\mathrm{Cp}$. i. $11 \mathrm{f}, n$.

79. Cp. Virg. Aen. vi. 389, 'comprime gressum;' Ovid, Met. viii. 218, ' aut pastor baculo stivave innixus arator.'

80. Cp. viii. 2-3, aestas mitior.

81. Cp. Virg. Ecl. vi. 47 , ah virgo infelix.

82. Cp. Ovid, Met. iii. $144 \mathrm{ff}$. (of Actaeon). 
85. Ovid, Met. iii. 415 (of Narcissus), dumque sitim sedare cupit, sitis altera crevit.

87. Ovid, Met. iii. 176, sic illum fata ferebant.

98. limbus: 'head-band,' 'fillet.' Cp. iv. 213 , frontem ligat auro; Claud. Cons. Mall. Theod. 118, frontem limbo velata pudicam; Arnob. ii. 41, imminuerent frontes limbis.

100. claviculo: 'pin.' The word is very rare ; cp. Nonius, p. 140 M., 'Maeander est picturae genus, adsimili opere labyrinthorum, claviculis inligatum.'

103-5. Cp. Virg. Ecl. viii. 4I, 'ut vidi, ut perii ;' Aen. iv. 2, 'et caeco carpitur igni ;' Ovid, Her. v. 143, 'me miseram, quod amor non est medicabilis herbis;' Mct. i. 523, 'hei mihi, quod nullis amor est sanabilis herbis;' Her. xvi. 190, 'flamma recens parva sparsa resedit aqua.'

107-8. Ovid, Met. xiii. 761-2, 'validaque cupidine captus | uritur, oblitus pecorum antrorumque suorum.'

108. Cp. Gregorio Tifernate (Mantuan's teacher), Triumphus Cupidinis, 'hic furit et noctes in fletu ducit amaras' (Venice ed., 1498, fol. b. iii).

I12. Sătānum. Mantuan has also Sătänas (acc. pl.) and Sătánibus (Ascensius' ed., Paris, 1513, Vol. i. fol. 164, 214 b).

121-2. Virg. Aen. iv. 602, epulandum ponere mensis; Ib. iii. 257, malis absumere mensas; Geor. iii. 268, malis membra absumpsere.

124-5. Cp. Cic. Tusc. Disp. i. 13. 30, 'quod nulla gens tam fera, nemo omnium tam sit immanis, cuius mentem non imbuerit deorum opinio.'

I26-8. Cp. Cic. $C . M$. xii. 40, 'hinc patriae proditiones, hinc rerum publicarum eversiones, hinc cum hostibus clandestina colloquia nasci.'

134. tetricos... Catones. Cp. Mart. x. 20. 21, 'tunc me vel rigidi legant Catones;' I6. 14, 'tetricae... Minervae;' Mantuan, Contra Poet. 15I, 'id cane quod tetrici possint audire Catones.' Iewis and Short give only títricus; Ovid and Martial have tëtricus. .

138. Psa. vii. 16, et incidit in foveam quam fecit.

140-2. Acts, xv. 10, 'nunc ergo quid tentatis Deum imponere iugum super cervices discipulorum quod neque nos neque patres nostri portare potuimus?' (Asc.). Virg. Aen. iii. 158, 'venturos ... nepotes.'

146. tranabit : cp. viii. 180, 'transiit ad Superos.'

147. ipsis. For this use of ipse, cp. viii. 112, 173. It is common in the Vulgate; and it occurs in Minucius Felix, $O c t .9 .3 ; 28.6$; $30.4 ; 30.5$. See the passage quoted from $J o h n$ (on $E c l$. iii. 75), the letter of Thomas Wolf, Jr., quoted on $\mathrm{Ecl}$. iv. 8r, the mediaeval document quoted on $E c l$. ix. 20.

151. $\operatorname{modo}=n u n c$, as in i. 4 .

154. Marius... Carbo. The early commentators could find very little point in these proper names. Ascensius suspected a play on the word carbo; Andreas Vaurentinus suggested that the names were loosely used, by a rustic speaker, 'like Pollux for Paulus (vii. I).'

167. Cp. Ovid, Her. vi. $2 \mathrm{t}$, credula res amor est.

172. Baldo: Monte Baldo (7275 ft.), east of the Lago di Garda. 
ECLOGA III, AMYNTAS.

\section{Agricolae duram sortem, miserique furores, Fortunatus et exitium deplorat Amyntae.}

In the third Eclogue Fortunatus completes the story which he had begun in the second. A part of the preliminary discussion (17-27 and 32-33) may be compared with Petrarch, Ecl. ix. (6-27 and 81-82).

1. Ila... grando. The reference is to $E c l$. ii. 173, oritur grando. 2-3. Cp. Mantuan's 3 Parthen. (fol. 147 Asc.), 'saepe boni quibus est hominum custodia divi $\mid$ et suus ipse oculis se subiecere videndos' (where Ascensius explains divi as meaning spiritus aut genii boni). In the De Sacris Diebus, divi regularly means the 'saints.' For divis gratia, cp. Ter. $A d$. 121 ;.Ovid, Pont. iii. 5. 48.

4. Harculus : see note on i. 148.

8. substantia = 'wealth,' as in the Ecclesiastical W-iters and in the Latin Bible. Cp. Juvencus, iv. 255; Paul. Nol. xviii. 56, ' geminos, quod ei substantia, nummos.'

12. gubernat. The earliest texts have the indicative, although the clause seems to be interrogative. Contrast involvat, 1. 31.

16. Virg. Ecl. viii. 35, 'nec curare deum credis mortalia quemquam.' extimo: 'extimare pro aestimare, interdum apud Script. Ecclesiasticos' (Du Cange). Mantuan has the form extimat again, 2 Parthen. ii. 519.

17-27. Petrauch, Ecl.ix. 6-27, ' rastra manu versans rigida scabrosque ligones | urget in arva boves sulcoque annixus inhaeret. $1 .$. postquam sudore exhaustus anhelo | spes cernit forere suas iamq a horrea laxat, | ecce, fremens sata culta truci vertigine nimbus | chruit, et longos anni brevis hora labores | una necat,' etc. Virg. Ecl. viii. 43, duris in cotibus. insidias intentat: cp. ii. 44, insidias tendebat. incalluit : cp. viii. 25, callosa.

31. Virg. Aen. i. 599, omnium egenos.

32-33. Petrarch, Ecl. ix, 81-82, 'falleris, ah demens; nam iusta et sera merentes / pastores ferit ira Dei populumque rebellem.'

39. Hor. Od. i. II. I, scire nefas.

40. Cp. ii. 78, nostrum repetamus Amyntam.

4I-42. Cp. i. I 8 , 'id commune malum, semel insanivimas omnes.'

43. Cp. i. 51, tollat de cardine mentem.

46. Cosmas is unfortunately hard to identify. Perhaps he is only an ideal person.

47. Cp. ii. 27, nostros repetamus amores.

50. Cp. Virg. Ecl. i. 30 and 68 , longo post tempore.

53. fabula. Cp. Hor. Epod. xi. 8, per urbem ... fabula quanta fui; Id. Ep. i. 13. 9, fabula fias; Ov. 4 m. iii. 1. 21 ; Tibull. i. 4. 83; ii. 3. 31 ; etc.

57. Cp. Tac. Ann. i. 34. 3, curvata senio membra.

59. somnolentum. The word is used with the same quantity in a mediaeval Latin poem (C. Pascal. Poesia latina medievale, Catania, 1907. p. 114). 
73. Contrast Mantuan's De Sacris Diebus (St. Urban's Day, May 25), ' iam tondentur oves.' Cp. Varro, $R$. $R$. ii. II. 7-8, 'oves hirtas tondent circiter hordeaceam messem, in aliis locis ante faenisicia. quidam has bis in anno tondent, ut in Hispania citeriore, ac semenstres faciunt tonsuras.'

75. conflare putabam. Cp. line 141, 'qui Aectere divos / creditis;' vi. 133, 'vertcre in aurum | aestimat;' and Mantuan's Alfonsus, Bk. iii (fol. 278), 'Bucarem Maurum qui fortibus armis | Hesperiam delere putans traiecerat aequor | perdonui.' So in the Latin Bible, John, v. 39, 'scrutamini scripturas. quia vos putatis in ipsis vitam aeternam habere.' Cp., also, Amm. Marc. xiv. 11, 34, scrutari putabit; Tertull. An. 38, tegere schserunt (E. Löfstedt, Beiträge zur Kenntnis der späteren Latinität, Uppsala, 1907, pp. 59-62).

83-85. Virg. Écl. iii. 71 , 'aurea mala decem inisi;' $/ b$. ii. 45-55, 'tibi lilia plenis / ecce ferunt Nymphae calathis,' etc.; /b. iii. 68.69, 'parta meae Veneri sunt munera: namique notavi / ipse locum, aeriae quo congessere palumbes.' Cp. Prop. iii. 34. 71, 'felix qui viles pomis mercaris amores.'

86. Ovid, $A$. $A$. ii. $277-8$, 'aurea sunt vere nunc saecula. plurimus auro | venit honos; auro conciliatur amor.'

87. Cp. ii. 167 , invida res amor est.

91. Cp. Ter. Phorm. 504, quoi quod amas domist.

97. Virg. Geor. ii. 76, aliena ex arbore germen.

103-8. Tibull. i. 1. 59-62, 'te spectem, suprema mihi cum venerit hora, | te teneam moriens deficiente manu. | flebis et arsuro positum me, Delia, lecto, | tristibus et lacrimis oscula mixta dabis;' i. 3. 57-8, 'sed me, quod facilis tencro sum semper Amori, I ipsa Venus campos ducet in Elysios.'

109. Virg. Aen. vi. 550, "quae rapidus flammis ambit torrentibus amnis, | Tartareus Phlegethon.'

I15. Virg. Geor. ii. 37I, 'texendae saepes etiam et pecus omne tenendum;' $I b$. iv. 10, 'neque oves haedique petulci | floribus insultent.'

$117-24$. Cp. Virg. Ecl. v. 40-44, spargite humum foliis, etc. ista : applied to what follows, as at viii. 95 .

130. Cp. Tibull. i. 1. $63-64$, 'flebis : non tua sunt duro praecordia ferro | vincta, neque in tencro stat tibi corde silex;' Ov. $A m$. i. 11 . 9, 'nec silicum venae nec durum in pectore ferrum.'

134. meos vultus averterit: apparently a variation on such Biblical phrases as Ps. 21, 25, 'nec averitit faciem suam a me;' $P_{s} .26,9$, 'ne avertas faciem tuam a me.'

138. Ovid, Met. i. 523, "hei mihi, quod nullis amor est sanabilis herbis.'

139. Virg. Geor. iii. 391, si credere dignum est (repeated, Aen. vi. 1\%3). So Ovid, Met. iii. 311 .

141. Virg. Aen. vii. 312, Aectere... Superos. With flectere... creditis $\mathrm{cp}$. line 75 , conflare putabam.

143-4. Cp. Virg. Geor. iii. 291-3, 'sed me Parnasi deserta per ardua dulcis | raptat amor; iuvat ire iugis, qua nulla priorum | Castaliam molli devertitur orbita clivo;' $I b$. ii. 47I, 'illic saltus ac lustra ferarum;'Aen. iii. 646, 'in silvis inter deserta ferarum | lustra.'

145. talia iactantem: a Virgilian phrase, Aen. i. 102; ii. 588; ix. 621. 
147. nox intempesta : a Virgilian phrase, Geor. i. 247; Aen. iii. 587 ; xii. 846. Cp. Lucr. v. 986.

150. Cp. Virg. Geor. iii. 528, simplicis herbae.

151. Cp. Catull. 64. 242, 'anxia in assiduos absumens lumina fletus.' 156. Virg. Aen. ii. 237, fatalis machina.

161. Cp. i. 52, 'nec deus (ut perhibent) Amor est, sed amaror et error.'

164. Virg. Aen. vi. 882, heu miserande puer.

165. Cp. Juv. vii. 194-6, 'distat enim, quae / sidera te excipiant modo primos incipientem | edere vagitus et adhuc a matre rubentem.'

167. Virg. Aen. ii. 87, primis...ab annis. infortunarit: cp. Mantuan's Trophaeum, Bk. ii (fol. 334), 'deo extremos infortunante labores.' Du Cange cites the verb only from a Paris missal: 'Deus ... quo benedicente nemo infortunabit.'

169. Virg. Ecl. x. 51, modulabor avena; Calpurn. i. 93, modulemur avena; Ib. iv. 63, carmen modulatus avena.

171. Juv. vii. 29, ut venias dignus hederis; Ovid, Met. xi. 165, lauro Parnaside vinctus.

174. Tityrus means Virgil, as in ii. 9. Cp. Virg. Ecl. ii. I, 'formosum pastor Corydon ardebat Alexim' (on which Servius says, ' Corydonis in persona Vergilius intellegitur, Caesar Alexis in persona inducitur'). In Juan del Encina's paraphrase of Virgil's second Eclogue King Ferdinand takes the place of Alexis.

179. Virg. Ecl. iv. 11, decus hoc aevi; Ib. v. 34, tu decus omne tuis; Ovid, Pont. ii. 8. 25, saecli decus indelebile nostri.

181. Ovid, Met. xi. 47," lacrimis quoque flumina dicunt | increvisse suis' (cited by Ioannes Murmellius).

182-5. Virg. Ecl. v. 24, ' non ulli pastos illis egere diebus | frigida, Daphni, boves ad flumina;' $I b .35$, 'ipsa Pales agros atque ipse reliquit Apollo;' Ib. 40, 'spargite humum foliis.'

188. Hebr. xi. 16, 'meliorem [patriam] appetunt, id est, coelestem.'

192-4. Virg. $E \mathrm{cl}$. vi. 85-86, 'cogere donec oves stabulis numerumque referre | iussit et invito processit Vesper Olympo.' For the 'star that bids the shepherd fold' (the a $\sigma-i j p$ ai ${ }^{2}$ cos of Apoll. Rhod. iv. 1630) cp. Calpurn. ii. 93-94, 'sed fugit ecce dies revocatque crepuscula Vesper; / hinc tu, Daphni, greges, illinc agat Alphesiboeus;' Nemes. ii. 89-90, "frigidus e silvis donec descendere suasit | Hesperus et stabulis pastos inducere tauros;' Boccaccio, Ecl. ii. 152.3, 'ast ocior Hesperus haedos | egit ut ad septas traherem, caprosque Melampus.' 


\section{ECLOGA IV, ALPHUS.}

\section{Amissum memorat caprum puerigue furoram Iannus, of ingenium notat hinc Alphws muliebre.}

The fourth Eclogue-the most famous of the series-is a satire on the ways of women. The topic had been a prime favorite with mediaeval writers : for some of the abundant literature on the subject, see A. Tobler, Zeitschrift für romanische Philologie, ix (1885), 288$290 ;$ D. Comparetti, Virgilio nel Medio Evo, ii. ${ }^{2} 112$ ff.; C. Pascal, Poesia latina medievale (1907), pp. 151-184, and Letteratura latina medievale (1909), pp. 107-115. Mantuan's discourse (lines 110-24I) is put into the mouth of one of his early teachers, Gregorio Tifernate - just how appropriately, it is hard to say. Certainly, there is nothing in Gregorio's published poems to suggest that he was a misogynist above all others of his day and generation. Possibly the youthful author meant merely to imply that his knowledge of the subject was only second-hand.

3.4. The symptoms of the sick animal are dutifully borrowed from Virgil; cp. Geor. iii. 466, medio procumbere campo | pascentem; Il. 465, summas carpentem ignavius herbas; Ecl. v. 26, nec graminis attigit herbam.

13. Virg. Ecl. iii. 69, quo congessere palumbes. philomena : for the spelling, see $i .27 n$.

15. qui non credit, etc. 'Quia qualis quisque est, talem iudicat quemlibet : et ita, qui fidus non est, neminem fidum existimat' (Ascensius); 'quia infidus et alios infidos putat' (Andreas Vaurentinus). Cp. the two 'emblemes' at the close of the May eclogue of Spenser's

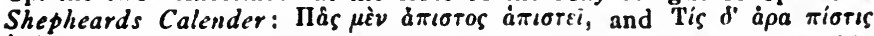
ärioty. Perhaps Alphus means that the man who does not trust his neighbor is not trusted (or trustworthy) himself.

17. Virg. Aen. ii. 13. incipiam. fracti bello, etc.

41. Virg. Aen. v. 591, irremcabilis error.

44. resero. The poet's brother Tolomeo defended a similar use of reserare, in the Alfonsus (animas reseraret ab Orco), by citing Virgil, Aen. ii. 258-9. 'inclusos utero Danaos et pinea furtim laxat claustra Sinon' (Apologia, Lyons ed., 1516, fol. Cc. v).

46-49. Cp. Thomas Middleton, The Witch (ed. A. H. Bullen, vol. v. p. 366). Further details as to the witches' flight, etc., may be found in Delrio, Disquisitiones magicae, lib. ii, quaest. I6 (Moguntiae, 1624, pp. 167 ff.).

52. pedum meditans. In some of the later editions the line is rewritten: dumque nemus subeo meditans mecum, ecce per umbras.

56. runcā: 'Runca dicitur ferreum instrumentum, seu sarculum, quo sentes et herbae runcantur aut evelluntur' (Du Cange).

7o. muliēribus. Cp. muliëre, iv. 206 and vi. 57; muliërum, iv. 245; Boccaccio, Ecl. vii. 124, mulieiribus. For the $\bar{c}$ in the oblique cases of mulier. Quicherat cites Venant. Fort. viii. 6; Dracontius, Satisf. 161: and it is not unconmon in mediaeval latin hexameters. 
The usage was criticized by Mantuan's contemporaries, but his brother Tolomeo could cite the authority of Laurentius Valla and Gregorio Tifernate (Apologia, Lyons ed., 1516, fol. Ee, iv).

81. Umber means Gregorio Tifernate (Gregorio da Cittd di Castello), as Mantuan himself explained to Thomas IVolf, Jr., in the year 1500: 'Ego, mi lacobe, sicut multa alia ita hoc praecipue quaesivi, quid ipse in aeglogis suis intelligi desyderaret per Vmbrum, in cuius lauclibus esset tam frequens ac assiduus. Aiebat ipse a se notari Gregorium tiphernum praeceptorem suum,' etc. (Letter to Jakob Wimpfeling, Feb. 24, 1503, printed in the Tübingen edition of the Eclogues, 1515). Gregorio was born about 1414. He studied at Perugia, and afterwards spent some years in Greece. Returning to Italy, he taught Greek at Naples, where (c. 1447) he had Gioviano Pontano as one of his pupils. From 1449 to 1455 he was in the service of Pope Nicholas V, for whom he made translations of several Greek works. After the death of his patron (March 25, 1455) he taught for a short time at Milan; and toward the close of 1456 he went to France, to the court of Charles VII. On Jan. 19, 1458 , he was appointed professor of Greek at the University of Paris; but early in Septenber, 1459, he returned to Italy. From April, 1460, to December, 1461, he seems to have taught at Mantua, and the remainder of his life was spent at Venice. He seems to have died about 1464. [The unpublished 'Vita' of Gregorio, Cod. l'at. Lat. 6845, foll. 157-161, contains very little information beyond what may be gleaned, or inferred, from his own poems. Some additional facts are furnished by $\mathrm{F}$. Gabotto, Ancora un letterato del Quattrocento (1890), pp. 7-23; L. Delaruelle, Mélanges d' archéologie et d' histoire, xix (1899), 9-33; L. Thuasne, Roberti Gaguini Epistole et Orationes (1903), i. 10-12].

82-83. Virg. Ecl. iii. 52, quin age, si quid habes; Ibid. ix. 45, numeros memini, si verba tenerem; Ib. ix. 38 , neque est ignobile carmen.

87-88. Cp. Virg. Ecl. iii. 20, 'Tityre, coge pecus;' tu post carecta latebas. For the rustic realism, cp. i. 44-47, and note. obsit: cp. iii. 115, ne floribus obsit.

90. Cp. i. 175, vineta subintrat.

93. 'et: i. e. etiam; pampineos... agros.: i. e. vineas' (Asc.).

98-99. Virg. Geor. i. 332, aut Rhodopen aut alta Ceraunia. Cp. 'Umber's' own reference to his long journeyings: 'I unior Eurotae potavi fluminis undam, | de Ligeri factus grandior amne bibo. | vidimus Oceanum mare, vidimus Hellespontum: | sic voluit longas nos Deus ire vias,' Gregorii Tipherni Poetae clariss.' Opuscula, Venetiis, 1498, fol. c. iii. [This quotation is taken from a copy in the Library of the University of Turin. There is another copy of the same edition at the University of Padua; anc Voigt-Lehnerdt report a third in the Royal Library at Berlin.]

100. referebat carmina. None of Gregorio's translations of Greek verse have been preserved. His translations of prose authors (all of them dedicated to Nicholas $V$ ) are as follows: ( 1 ) Aristotle, Magna Moralia and Eudemian Ethics; (2) Dio Chrysostom, De Reguo; (3) Strabo, D. Situ Orbis. lib. xi-xvii (the first ten bocks 
were translated by Guarino); (4) Theophrastus, four fragments (Metaphysica, De Natura Ignis, De Piscibus, De Vertigine); (5) Timaeus Locrensis, De Mundi Fabrica. [I owe this note to Dr. D. P. Lockwood, of Columbia University.]

105. Candidus means Mantuan himself, as in Eclogues IX and X. Cp. the reference in Euricius Cordus, Ecl. ii, 'Candidus est, gelida qui Faustum lusit in umbra, | ut retulit veteres Gallam quibus arserat ignes.'

108. Virg. Ecl. vii. 21, Nymphae, noster amor, Libethrides.

109. plus: 'subaudi caeteris. alioqui dixisset plurimum' (Ascensius).

I10. Cp. a letter of Aeneas Silvius (to Hippolytus of Milan, 1446), Remedium contra amorem: 'Mulier est animal imperfectum, varium, fallax, multis moribus passionibusque subiectum, sine fide, sine timore, sine constantia, sine pietate. de his loquor mulieribus quae turpes admittunt amores.' For a longer string of such uncomplimentary epithets (with a similar saving clause at the end) sec Martinez de Toledo, Corvacho (1438), Madrid ed., r9or, p. 6r. Cp., also, Boccaccio's Corbaccio (Florence ed., 1828, p. 199): 'Ora io non $t$ ' ho detto quanto questa perversa moltitudine sia golosa ritrosa e ambiziosa, invidiosa nccidiosn iracunda e delirn, nd qunnto ella nel farsi servire sia imperiosa noiosn verzosn stomucosn e importunu, e altre cose assai,' etc.

112. extremis gaudet. So La Bruyère, Jis Femmes, 53, 'Les fenmes sont extrêmes: elles sont meilleures ou pires que les hommes.'

114. Virg. Geor. i. 211 , brumac intractabilis.

115. Virg. Aen. x. 273-5, 'aut Sirius ardor | ... laevo contristat lumine caelum.' Canis is probably the genitive.

I17. amat...odit. Cp. Publil. Syr. Sent., 'aut amat aut odit mulier, nil est tertium;' also, the line in a mediaeval poem, 'Aut amat aut odit: medium non femina novit' (C. Pascal, Poesia latina medievale, Catania, 1907, p. 179). capitaliter odit: the expression is cited from Amm. Marc. 21. 16. 11 .

118. hernica: cp. Mantuan's Alfonsus, Bk. ii (fol. 269), 'facili minus hernica vultu.'

124. Cp. Virg. Aen. iv. 569, varium et mutabile semper | femina.

129. găneae: 'gluttony.' For the quantity, cp. Prud. IIamart. 322, gänconis; Id. Psych. 343, gănearum; Sidon. v. 340, gănea.

132-3. Ovid, Met. ii. 467, distuleratque graves in idonea tempora poenas.

134. litigiosa: cp. Juv, vi. 242, 'nulla fere causa est in qua non femina litem | moverit.'

$135 \mathrm{ff}$.: echoed in Two Italian Gentlemen (1584), 938-943, Malone Society Reprint, 1910, through L. Pasqualigo (see p. 56): 'Busie they are with pen to write our vices in our face, But negligent to knowe the blemish of their owne disgrace. Gestures and lookes in readinesse at their command they haue. Mirth, sorrowe, feare, hope,' etc.

146-9. $\mathrm{Cp}$. the close of the fable 'De muliere et proco suo' ( $\mathrm{L}$. Hervieux, Les fabulistes latins, ii. 487): 'Hic dicitur, quod mulier habet omnes artes Dyaboli et adhuc ulterius artem unam. De visis enim decipit veluti de non visis.' 
$150 \mathrm{ff}$. The examples cited, here and in lines $207 \mathrm{ff}$., had long been stock examples in treatises on this subject. Cp. St. Jerome, Adv. Iov. Bk. i. (ii. 292 Migne), 'quid referam Pasiphaen, Clytemnestram, et Eriphylam . . . quidquid tragoediae tument, et domos urbes regnaque subvertit, uxorum pellicumque contentio est. armantor parentum in liberos manus: nefandae apponuntur epulae: et propter unius mulierculae raptum Europa atque Asia decennali bello confligunt.'

156. sŭbicit: cp. Lucan, vii. 574, ipse manu sübicit gladios; Sil, Ital. i. 113, sübicilquc haud mollia dicla.

161. Iuxuriae means 'lust', as in the Ecclesiastical Writers: Paul. Nol. xxv. 10; Prudent. Perist. xiii. 25 ; etc.

176. The names all occur in Virgil's Eclogues.

178. An unusual version of the story. C. G. Leland, Legends of Florence, New York, 1895, p. 236, mentions 'the fact that Eurydice was lost for tasting a pomegranate,' but omits to state where the 'fact' is recorded. Cp. Ovid, Mlet. ix. 600, si non male sana fuissem.

180. Virg. Geor. i. 39, ' nec repetita sequi curet Proserpina matrem.'

181-3. Virg. Aen. vi. 119-23, 'si potuit manes arcessere coniugis Orpheus | ...si fratrem Pollux alterna morte redemit, | itque reditque viam totiens-quid Thesca magnum, | quid memorem Alciden? et mi genus ab love summo;' llor. Od. 1. 12. 26, 'hune equis, illum superare pugnis | nobilem.'

184. Boccuccio, Ecl. xiv. 207 (of the Redeemer), inde salus venit at vila renatis.

194-5. Cp. iii. 65-66.

196-7. Cp. Brunetto Latini, Li Tresors, i. 5. 132 (of the Cocodrille), 'Et se il vaint l' ome, il le manjue en plorant;' Ib. i. 5. 191 (of the Hiene), 'et ensuit les maisons et estables, et contrefait la voiz des gens, et ainsi decoit sovent les homes et les chiens, et les devore;' Philippe de Thaün, Bestiaire, 717-18 (of the Cocodrille), ' $S$ ' il pot, ume devure, | Quant mangié l' at, si plure;' Perotti, Cornucopiae (of the crocodile), 'conspecto homine emittit lacrimas; mox appropinquantem devorat;' (of the hyena), 'humanum sermonem inter pastorum stabula assimilare dicitur, nomenque alicuius discere quem foras evocatum dilaceret. vomitionem etiam hominis imitari ad sollicitanilos canes quos invadat;' Cecco d'Ascoli, Xi (of the hyena), 'contrafa lhumana uoce | per deuorar lhumana creatura' (Venice ed. 1487) ; Mantuan, Alfonsus, Bk. v. fol. 293, 'callida et, ut perhibent, nostrae aemula vocis hyaena.'

200-1. Ovid, Met. iv. 780-1, 'se tamen horrendae clipei quem laeva gerebat | aere repercussam formam aspexisse Medusae;' Ib. 55 I, 'saxificae... Medusae;' Met.'v. 217, 'saxificos vultus... Medusae.'

204. fluviorum: for the scansion, cp. Virg. Geor. i. 482, fluviorum rex Eridanus. aspris: for the form, cp. Virg. Aen. ii. 379, aspris ....sentibus.

207 ff. 'Plebeii ac triviales sunt versiculi : Adam, Samsonem, Lot, Davidem, Solomonem, | Femina decepit; quis modo tutus erit?" (Ascensius).

212. Prud. Hamart. 264-5, 'nec enim contenta decore / ingenito externam mentitur femina formam.' 
213. Prud. Hamart. 272, 'aureolisque riget coma texta catenis.' 216. Cp. Virg. Ecl. iii. 64-5, 'malo me Galatea petit, lasciva puella, I et fugit ad salices, et se cupit ante videri.'

217. dare. Cp. Catull. cx. 4, 'nec das et fers saepe.'

218. Cp. Ov. $A$. A. i. $665-6$, 'pugnabit primo fortassis et 'improbe' dicet: | pugnando vinci se tamen illa volet.'

219. Gellius, ii. 22. 24, 'est etiam ventus nomine caecias, quem Aristoteles ita flare dicit ut nubes non procul propellat, sed ut ad sese vocet, ex quo versum istum proverbialem factum ait: "E $\lambda_{k \omega \nu}$ i $\phi^{\circ}$ aivìv

222. hic fragilis... sexus. Cp. Prud. Hamart. 277, 'haec sexus male fortis agit, cui pectore in arto / mens fragilis facili vitiorum fluctuat aestu.' Cp., also, the poem Alda (du Meril, Poésies inédites du moyen age, Paris, 1854, p. 430), fragili rigor in sexu; and the expression femina res fragilis, in two other mediaeval poems (C. Pascal, Pocsia latina medicvale, pp. 154, 155).

233. Cp. Virg. Geor. i. 93, penetrabile frigus.

234. Petrarch, Ecl. i. 87, Stygias Rammas.

236. Virg. Aen. iii. 216 , 'foedissima ventris / proluvies;' Ib. 227, 'diripiuntque dapes contactuque omnia foedant immundo.'

239-40. Lucan, Phars. ix. 624, 'finibus extremis Libyes, ubi fervida tellus| accipit oceanum demisso sole calentem, | squalebant late Phorcynidos arva Medusae.' These lines are quoted by Perotti, and ascribed to Ovid; and Ascensius borrows both the quotation and the false reference in his commentary on Mantuan.

244. rèi. For the quantity, cp. Lucr. ii. 112,548 ; vi. 918.

247. urbi : Città di Castello, on the upper course of the Tiber. It occupies the site of the ancient Tifernum Tiberinum. Cp. Virg. Ecl. vi. 73, quo se plus iactet Apollo.

249-50. Juv. vii. 55, carmen triviale.

25I. Virg. Ecl. x. 33, quam molliter ossa quiescant.

\section{ECLOGA V, CANDIDUS.}

Otia Sylvanus miratur inertia vatis, Candidus abiectos queritur nuthc esse poetas.

The fifth Eclogue lifts up an old complaint against the niggardly attitude of rich men toward poets-against 'these frugal patrons, who begin | To scantle learning with a seruile pay.' Like the fourth, it was a youthful composition on a traditional subject-a subject which had been touched on by Theocritus, and Juvenal, and Martial, and Petrarch-and it cannot reflect anything in the author's own experience. It is paraphrased in Alexander Rarclay's fourth Egloge 'treating of the behauour of Riche men agaynst Poetes,' and imitated in the Oc.uber Aeglogue of Spenser's Shiphiards Calender. 'E. K.'s' comment on Spenser's poem states that 'this Aeglogue is made in imitation of Theocritus his xvi. Idilion,' adding-what most of his 
readers were likely to know-' and the lyke also is in Mantuane.' But this comment is misleading, and must have been intended to be misleading. Spenser's indebtedness to Theocritus is exceedingly slight; but it would doubtless be more impressive to refer one of his poems to a great Greek model than to the 'homely Carmelite' whose Eclogues were a familiar text-book in almost every school.

2. Virg. Ecl. v. 2, calamos inflare.

6. Cp. Juv. iii. 165 (and vi. 357), res angusta domi; Cic. Phil. xiii. 4. 8, res familiaris ampla.

7-8. Virg. Geor. iii. 177, nivea implebunt mulctraria vaccae; Aen. iii. 66, spumantia cymbia lacte.

9. Pers. i. 45, si forte quid aptius exit.

10. extenditis aures: $\mathrm{cp}$. Seneca, $E_{p}$. xl. 3 (of the proper delivery for philosophical teaching), nec extendat aures nec obruat.

I1-12. Juv. vii. 30-32, 'didicit iam dives avarus | tantum admirari, tantum laudare disertos, I ut pueri Iunonis avem;' 'So praysen babes the Peacoks spotted traine,' Spenser, $S$. C. x. 31; T. Randolph, $A n$ Eclogue to Master Jonson, ' Rich churls have learn't to praise us, and admire, | But have not learn't to think us worth the hire.' Cp., also, Juv. i. 74, 'probitas laudatur et alget.'

16. saepe : abl. of saepes.

25. Virg. Ecl. ix. 51, omnia fert actas.

27. Cp. Tibull. ii. 5. 25, pascehant herbosa Palatia vaccae; Virg. Ecl. ii. 42, bina die siciant or'is ubera.

28. Cp. Juv. vii. 34-5, 'taedia tunc subeunt animos, tunc seque suamque | Terpsichoren odit facunda et nuda senectus.'

29. secundant. For the intransitive use, cp. Boccaccio, Ecl. vi. 47, da coepta secundent.

32. altera $=$ alia.

33. Cp. Juv. vii. 32-3, 'sed defluit aetas I et pelagi patiens et cassidis atque ligonis;' Virg. Aen. i. 599, omnium egenos.

38. fruges secat ore. This bit of natural history was recorded in the famous Greek treatise Physiologus. Cp. E. Peters, Der griechische Physiologus und seine orientalischen Uebersetzungen, Berlin, 1898, p. 89, "Wenn sie (sc. die Ameise) die Nahrung in der Erde aufspeichert, so beisst sie die Körner in zwei Stücke, damit nicht die Körner während des Winters keimen und sie Hunger leidet.' Cp., also, Philippe de Thaün, Bestiaire, 931-4, 'Le grenet que il at | En dous parz le fendrat; | Issi fait cuintement | $Q \mathbf{u}^{\prime}$ en iver faim nel prent; ' Guillaume le Clerc, 937-40, 'Chescun son grein par mileu fent | E ensi le garde et defent, $Q \mathbf{Q} \mathbf{\prime}^{\prime}$ il n' empire ne ne porrist | Ne que nul germe n' i norrist ; ' Brunetto Latini, Li Tresors. i. 5. 190, 'et ses grains brise tous parmi, porce que il ne puissent naistre à la moistor de la terre;' and (for Mantuan's own day) Perotti's Cornucopiac, 'semina condunt semirosa, ne rursus in fruges exeant.'

46. Petrarch, Ecl. iv. 68, 'sorte tua contentus abi, citharamque relinque.'

58. fac nos gaudere. Facere with the infinitive in the sense of "to cause to" is common in the Ecclesiastical Writers. "This 
construction seems to have been colloquial : we find it at least once in Cic. (Brut. 142), in Lucr., Varr., Ou. and Col. Its presence in Verg. A. 2. 538-9, is only one of many instances of V's taste for the communis sermo" (W. C. Summers, Select Letters of Seneca, London. 1910, p. 350).

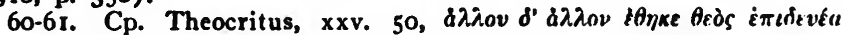
pwriuv (quoted by Florido Ambrogio, p. 131).

64. faxo: archaic, as in Aen. ix. 154; xii. 316.

65. nodum Herculis. Cp. Macrobius, i. 19. 16, 'in Mercurio solem coli etiam ex caduceo claret, quod Aegyptii in specie draconum maris et feminae coniunctorum figurauerunt Mercurio consecrandum. hi dracones parte media uoluminis sui in uicem nodo, quem uocant Herculis, obligantur,' etc.

67. inquis = dicis. Cp. viii. 67, quod... inquis; x. 53, ut Candidus inquit.

70. $\mathrm{Cp}$. Ov. Tr. i. 1. 39, 'carmina proveniunt animo deducta sereno ;' Juv. vii. 53-56, 'sed vatem egregium ... anxietate carens animus facit;' Ib. $63-64$.

72. squarrosa : a rare word, cited only from Lucilius: 'squarrosi a squamarum similitudine dicti, quorum cutis exsurgit ob assiduam illuviem.' situs occupat ora: cp. Virg. Aen. iv. 499, pallor simul occupat ora; Tibull. i. 10. 50, occupat arma situs.

75. Cp. iv. 67, 'ut ad formam faciat pudor.'

78. Cp. 'Itala,' Ps. 143. I3, cellaria eorum plena.

80. Virg. Ecl. i. 36, 'gravis aere domum mihi dextra redibat.'

82. ludos inarare: 'id securi faciunt rustici, divinare facientes quem sulcum tetigerint' (Asc.).

86. Tityrus means Virgil, as in ii. 9.

89. Cp. Mart. viii. 55. 5, 'sint Maecenates, non derunt, Flacce, Marones;' Juv. vii. 69-71, 'nam si Vergilio puer et tolerabile desset | hospitium, caderent omnes a crinibus hydri, | surda nihil gemeret grave bucina.'

90-91. Cp. Juv. vii. 59-61, 'nec enim cantare sub antro | Pierio thyrsumque potest contingere maesta | paupertas' (' $\mathrm{Ne}$ wont with crabbed care the Muses dwell,' Spenser, $S . C$. x. 101).

96. Cosmi: Cosimo de' Medici, 'the Elder' (1389-1464). His wealth was proverbial; cp. a letter of Aeneas Silvius (to Petrus Noxctanus, 1446): 'Non habes opes Cosmi: at Marcelli habes.'

97. Pers. i. 67, in luxum et prandia regum.

98. patinam Aesopi. Plin. N. H. x. 51, 141, 'Clodi Aesopi tragici histrionis patina $H S \vec{c}$ taxata, in qua posuit aves cantu aliquo aut humano sermone vocales, HS $\overline{v i}$ singulas coemptas, nulla alia inductus suavitate nisi ut in his imitationem hominis manderet,' etc. This 'patin of Esope', as Alexander Barclay translates it, was proverbial. Beroaldo has, 'I Iam patina Esopi caedat: iam luxus Apici : I et Ptolomeorum prodiga luxuries' (In caenam datam principi Bentivolo a Mino Roscio, Lyons ed. 1492). Cp. also, the Lamentationes novae obscurorum Reuchlinistarum, xi (Henricus Haversack to Joannes Smoerpot), "Vale ad longos Nestoris annos, et Aesopi patinas nobis ad caenam para.' clipeumve Minervae. Sueton. Vit., xiii. 2, 'patinae, quam ob immensam magnitudinem 
sliperm Mincrvae nohcobxov dictitabat. in hac scarorum iocinera, phasianarum et pavonum cerebella, linguas phoinicopterum...commiscuit.' [These two phrases were explained by Ioannes Mfurmellius, in his Scoparius (1517).]

- 99. regis laribus. Nero's Golden House (Sneton. Nero, 31).

100. aenea barba: Aenobarbi, a family name of the Domitian gens (Sueton. Nero, 1).

101. The speaker explains his more than pastoral enlightenment: cp. vi. 58-59; vii. 10 ; viii. $153-5$; ix. 200 ; also, vi. 220 and note.

104. Juv. Xv. 173.4, 'Pythagoras, cunctis animalibus abstinuit qui I tamquam homine et ventri indulsit non omne legumen;' Ib. iii. 229, 'unde epulum possis centum dare Pythagoreis;' Ib. iii. 203. 'lectus erat Codro Procula minor, urceoli sex,' etc.

108-9. Cp. ii. $45-47$.

109. Hor. Ep. i. I. 4-5, armis | Herculis ad postem fixis.

123. Cp. Hor. Ep. i. 6. 37, regina Pecunia; Juv. i. 112, inter nos. sanctissima divitiarum | maiestas.

129. subsannet. The verb is a common one in the Latin Bible and in the Ecclesiastical Writers: e. g. 2 Par. 30. 10, illis irridentibus et subsannantibus eos.

136. Petrarch, Ecl. iv. 70, posceris auxilium: tu consulis? Mart. ii. 30, 6, quod peto da, Gai: non peto consilium. sed. The Bologna edition of 1502 reads sum.

145 ff. Cp. T. Lodge, $A$ Fig for Momus (1595), Ecl. iii, 'To Rowland': 'But now, these frugal patrons, who begin | To scantle learning with a seruile pay, | Make Poets count their negligence no sinne: The cold conceit of recompence doth lay | Their fierie furie when they should begin. |. The priest unpaid, can neither sing nor say, | Nor poets sweetlie write, excepte they meete | With sound rewards, for sermoning so sweete.'

151. gănea. Sce iv. 129 n.

166 if. Cp. Palingenius, Zodiacus Vitae, ii. 549 (Basel ed., 1548, p. 29): 'si qua tamen donant, dant scurris, dantque cynaedis, I dant lenis potius, dant scortis callipareis: I nemo dabit vati, Musae spernuntur ubique.'

176. trivialibus: cp. iv. 249-50, trivialia ... carmina.

181. Cp. Hor. Ep. i. 10. 29, vero distinguere falsum.

190. Cp. Hor. Ep. i. 1. 52, vilius argentum est auro, virtutibus aurum.

ECLOGA VI, CORNIX.

Cornix enarrat discrimina ruris et urbis, Et pergit varios stultorum carpere mores.

Fulica repeats a story which explains that the difference between the lot of the countryman and that of the townsfolk was fixed at the very beginning, when the Creator ordained that some of Eve's younger children should be shepherds, and ploughmen, and laborers in the field. Cornix retorts with a lively satire on the evils of life 
in a city. The poem is paraphrased in Alexander Barclay's fifth $E_{\text {gloge }}$ ' of the disputation of Citizens and men of the Countrey.'

1-5. Cp. the winter picture at the close of Love's Labour's Lost: - When icicles hang by the wall ... While greasy Joan doth keel the pot.'

5. polenta, used as neuter singular; cp. viii. 23, pingue polenta. Mantuan's defence of this usage is quoted in his brother Tolomeo's Apologia (Lyons ed., 1516, fol. Cc, vii): "cum audisset sibi vitio dari quod neutro genere polenta dixisset, paulum subrisit et, ut est facetus, in me conversus ait: 'hui me miserum, Ptolemaee, vocor in iudicium de polenta quod non edi;' et continuo attulit versus illos ex quinto libro Metamorphoseon Nasonis <449-450>:

prodit anus divamque videt lymphamque roganti

dulce dedit testa quod coxerat ante polenta,

et paulo infra $<453-454>$ :

offensa est, nec adhuc epota parte loquentem

cum liquido mixta perfudit diva polenta.

in primis duobus versibus iungit dulce cum polenta; in aliis duobus dicit cum liquido polenta. quo essent et critici nostri iure perfundendi, et in stelliones deformesque bestiolas convertendi. Philippus Beroaldus in sextum librum Apulei de aureo Asino loquens de polenta dicit: 'apud Ovidium neutraliter enuntiatur illo versu, dulce dedit testa quod coxerat ante polenta." [Met. v. 450 is quoted by Mantuan, and by Beroaldo (Bologna ed., I500, fol. Y. ii), as it stands in the fifteenth-century editions, Vicenza, 1480, Venice, 1486, etc. Modern editors give an 'emended' line: 'dulce dedit tosta quod texcrat ante polenta.']

22-23. Cp. I Parthen. iii (of the Nativity), 'deciderant umbrae nemorum, sine crinibus omnis | arbor erat nidosque avium monstrabat inanes.'

26. vulpes $=$ pelles vulpinas (Asc.).

27. melotas $=$ pelles ovinas (Asc.). Cp. Hebr. ii. 37, " circuiernnt in melotis, in pellibus caprinis.' trahunt = contrahunt (Asc.). Virg. Aen. i. 323, maculosae tegmine lyncis.

30. mater... noverca. Beroaldo has a similar fancy, Fortuna, ad Minum Roscium, 'hcs ut mater alit: illos ut saeva noverca | exagitat: fovet hos: his inimica nocet' (Orationes et Poemata, Lyons ed., 1492). Cp. the beginning of Pliny's seventh book (of Nature), 'non ut sit satis aestimare, parens melior homini an tristior noverca fuerit;' and Mantuan's Dialogus contra Detractores (Lyons ed., 1516, fol. a, viii): 'Dixit etiam Exopus, ut in eius vita legisse me memini, terram malis herbis esse matrem, bonis novercam. est etiam apud Graecos illud adagium: cst quandoque dies mater, quan-

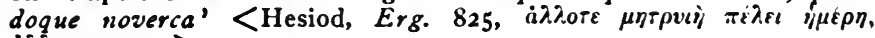
dij.ore $\mu \eta \tau \eta \rho>$.

- 31-2. Cp. Juv. vii. 191, felix et sapiens et nobilis et generosus, etc.

45. Virg. Geor. iii. 355, septemque assurgit in ulnas.

52. accubitu: 'bed'. 'Accubitus pro cubatu, aut cubitu, Gall. la couchée' (Du Cange).

57. muliēre. $\mathrm{Cp}$. iv. 7o, and note. 
58. Ov. Met. i. 79, ille opifex rerum; Prud. Hamart. 116, ipse opifex rerum.

61. Virg. Aen. ii. 235, accingunt omnes operi.

70. sine con vibus hirci = foedi adulteri (Asc.).

97. Virg. E. iii. 101, pecorisque magistro.

101. genus hoc. Cp. Hor. Sat. ii. 6. 44, nugas hoc genus.

105. Mantous Amyntas. The same Amyntas as in Ecl. ii; cp. 107, civis erat, with ii. 132, civis enim fuerat puer et versatus in urbe.

113. Alexander Barclay, $E \mathrm{cl}$. v, translates, 'But thou art so rude, thy paunche is so fatte.' And, as Shakespeare's Longaville remarks, 'Fat paunches have lean pates' (L.L.L. i. 1. 26); or, as Thomas Lodge puts it, A Fig for Momus ('To his Mistres A L.'), 'Of such doe Basile, Galen, Plato, write, I That fattest bellie hath the weakest sprite' Cp. Hor. Sat. ii. 5. 40, pingui tentus omaso; Perotti, Corn., ' nam omasum appellamus intestinum pingue' (Venice

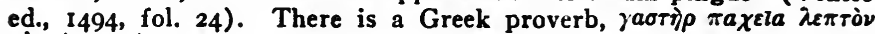

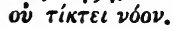

115. Cp. v. 10, placidas extenditis aures.

117. Cp. i. 83, fulgenti murice.

119. Cp. i. 84, quos vidi elatos regali incedere passu.

128. Cp. v. 14, vitam traducere.

132. ab aevo. Cp. Vulg. Sirach, i. 4, 'prior omnium creata est sapientia, et intellectus prudentiae $a b$ aevo;' Tert. Scorp. 6, 'ab aevo dignissimum creditum est.'

133-4. vertere ... aestimat. Cp. iii. 75, conflare putabam. fuligine pallet. Cp. Mantuan's Trophaeum, Bk. v. (fol. 367), caede madens et pulvere pallidus atro; also, his First Parthenice, Bk. iii, obscurae pallentia ftumina Lethes (Ascensius' ed., Paris, 1513, fol 74).

140. Cp. Mart. iii. 79. I, rem peragit nullam Sertorius, inchoat omnes.

149. Cp. v. 112, copia rerum | tantarum; Virg. Aen. iv. 233, tantarum gloria rerum.

157. Cp. Calpurn. Ecl. iv. 25, et lac venale per urbem non tacitus porta.

167. quid reges: the verb omitted, as in Virg. Geor. iii. 258, quid iuvenis, etc.

175. Virg. Geor. ii. 503, sollicitant alii remis freta caeca.

177-9. Cp. Hor. A. P. i io, inventis miser abstinet ac timet uti; Ep. i. 5. 13, parcus ob heredis curam nimiumque severus I assidet insano; Ter. Phorm. 44, suom defrudans genium.

189. sinunt $=$ desinunt (Asc.).

193. pietas. Cp. viii. 157, 164; also, Du Cange, 'pitié, idem quod aumône, in testam. ann. 1366.'

199. Prud. Hamart. 401, inde canina foro latrat facundia toto; Quint. xii. 9. 12, si a bano viro in rabulam latratoremque convertitur; Cic. Or. xv. 47 , rabulam de foro.

203. equestre genus. 'Et hoc quoque satyrice. Equestres sunt, quia mulis fere vehuntur medici' (Asc.).

206. Cp. Deut. 28. 29, sicut palpare solet caecus in tenebris.

210 . Cp. Virg. Geor. ii. $486, o$ ubi campi, etc.

21 (1. Plin. $N . H$. iii. 8. 78, 'Ebusi terra serpentes fugat;' Perotti. 
C'orn. fol. 112, 'inter hanc (sc. Ophlusam) et Pytiusam Ebosus ost cuius terra serpentes fugat.'

220. Plin. N. HI. x. 29, 76, 'quarum (sc. noctuarum) genus in Creta non esse, etiam, si qua invecta sit, emori;' Perotti, Corn. fol. 15I, 'quae in Creta non est, et si qua invehatur non multo post moritur.' The unlettered speaker forgets the name, as in Virgil, $E c l$. iii. $4^{n}$, quis fuit alter, etc. Cp. the pastoral simplicity of vii. 28 ; viii. 87 ; viii. 150 ; and contrast v. Ior, and note.

221. Virg. Aen. vii. 778, 'unde etiam templo Triviae lucisque sacratis | cornipedes arcentur equi.'

240. Virg. Geor. i. 153-4, 'interque nitentia culta | infelix lolium et steriles dominantur az'enae;' Ecl. v. 37.

246. fons et origo. Cp. Flor. Epit. i. 41. 12, in originem fontemque belli Ciliciam; Prud. Sym. i. 72, haec causa est et origo mali; Palingenius, Zod. Vitae, vi. 191, stultitiae fons est et origo philautia vestrae.

252. ulla. Cp. Mantuan's Trophaium. Bk. v. fol. 369, 'iacturam hanc lucro ullo alias fortuna rependet.'

\section{ECLOGA VII, POLLUX.}

Galbula pastores ad sidera laudibus effert, Et canit. ut viso versus sit numine Pollux.

The seventh Eclogue reports a vision in which the youthful Pollux is warned against the clangers of the world, and pointed to the safe retreat of Mount Carmel. IJere Pollux is cominonly supposed to mean Mantuan himself; but the poen was written before he joined his religious order. See, also Introduction, p. 19. Lines 9.56 are paraphrased in Alexander Barclay's fifth Egloge; lines 14-31 are echoed in Spenser's July Acslogue, 129.157; lines 9.39 are paraphrased in the third Eglogue of Francis Sabie's Pan's Pipe, Damon's 'dittie', of the 'stately progeny of heardsmen.'

1. Pollux: see note on $i .148$.

10. Umber. See iv. 8I $n$.

I1. Cp. vi. 97, and Virg. Ecl. iii. 101, pecorisque magistro.

14. ast. An archaic form, as in Virg. Aen. i. 46 ; ii. 467.

18. Virg. Ecl. iii. 77, cum faciam vitula.

20. Cp. iii. 141, fectere dizos; Virg. Aen. vii. 312, Rectere... Superos.

23. Assyrios: 'ut Abraham, Lot, lacob, et caeteros patriarchas' (Asc.). Cp. the excuse for forgetting at viii. 95.

25. postea : here probably a dactyl, as it is at viii. 47.

26. Virg. den. i. 21 , populum late regem belloque superbum.

33. deitatis: Inte Latin for divinilalis, as in Aug. Civ. Dei, vii. 1. Prud. A poth. 144, etc.

37. Tonantem: cp. Ov. Met. i. 170 ; ii. 466 , etc. It is a bit of 
traditional criticism to say that Mantuan made too free use of pagas imigery; and his frequent use of Tonans is always cited in this connection. But he had good authority for borrowing the word for Ch:istian use: Paul. Nol. xxii. 149; Juvencus, ii. 795 ; iv. 553,672 , 786; Prud. A poth. 171; Cath. xii. 83.

39. magos regesque. In the De Sacris Diebus ('De Epiphania') Mantuan rejected the tradition that the Magi who came to worship the infant Saviour were kings: nec reges, ut opinor, erant.

40. John, X. 14, ego sum pastor bonus.

43. Cp. Virg. Aen. vi. 33, omnia perlegerent oculis.

45. divum: 'aut regum aut angelorum Christi et parentum eius' (Asc.). The 'kings' were a regular feature in paintings of the Nativity. Or divum may be used as it is used in the First Parthenice, of the 'multitude of the heavenly host' which appeared to the shepherds: agmen divorum.

59. Cp. Virg. Ecl. iii. 33, 'est mihi namque domi pater, est iniusta noverca.'

72. duces suspiria. Cp. 76, trches...gemitus; also, C. Erasmns Laetus, Ecl. v. 24, 'quid gemitus trahis et maestus suspiria ducis?'

75. Ovid, Met. iv. 683, lumina ...lacrimis implevit. quod lumina : 'legrendum videtur tot, ut sit: pectus, inquam, quod implet toties lumina tot fletibus' (Asc.). Perhaps Mantuan wrote tua lumina.

79. fas erit =licebit. Cp. 8o-81, sed fas mihi fere, quod illi non licet; x. 66, qua noxia pabula fas est | disccre.

8i. Virg. Aen. i. 688, ociultum ignem; Ovid, Met. iv. 64, queque magis tegitur, teitus magis aestuat ignis. Cp., also, Two Gentlemen of Verona, i. 2. 30, 'Vire that's closest kept burns most of all.' and the Cambridge play Laclia, i. 3. $145 \cdot 6$, 'quantum potui, celavi, sed amor ignis est: | quo magis foves, eo erumpit ardentius.'

87. Cp. Sueton, Iul. 32, iacta alea est.

88. fronde sub Herculea : an allusion to the 'Choice of Hercules.' Cp. Virg. Ecl. vii. 6s, populus Alcidae gratissima.

89. Viri. Aen. i. 497, magna iuz'enum stipante caterva.

9o. Virg. Aen. i. 589, os umerosque deo similis; 1b. iv. 558, ommia Mercurio similis, vocemque coloremque | et crines Ravos of membra decora iuventa.

92. Virg. Aen. vii. 7, tendit iter; 16. i. 656, iter... tendebat.

93. Virg. Ecl. ix. 1, quo via ducit.

97. Virg. Geor. ii. 154, in spiram tractu se colligit anguis.

98. Virg. Ecl. iii. 93, latet anguis in herba.

102 ff. Cp. the 'Laberinto d' Amore' in Boccaccio's Corbacsiowhere the 'spirit' of Boccaccio's vision corresponds to Mantuan's 'nymph'.

106.8. Ovid, Met. X. 53-54, trames | arduus, obscurus, caligine densus opaca.

112-14. Ovid, Met. xiv. 279-8I, 'saetis horrescere coepi I nec iam posse loqui, pro verbis edere raucum | murmur et in terram toto procumbere vultu.'

116. Virg. Aen. i. 419, collem qui plurimus urbi I imminet.

125. mini. The identity of the 'nymph' is disclosed: Our Lady of Mount Carmel. 
130. Cp. Ovid, Am. iii. 9, 25, 'adice Maconiden a quo, ceu fonte perenni, vatum Pieriis ora rigantur aquis;' Ronsard, Hymnes, ii. 7. 40, 'Homere, | De qui, comme un ruisseau d' âge en âge vivant, La Muse va tousjours les poetes abreuvant.'

138. Cp. Boccaccio, Ecl. xiv. 213-21, 'stat Satyrum longaeva cohors ... roseis ornata coronis,' etc.

144. cadet. The earliest editions have the future.

147. Ovid, Rem. Am. 91, principiis obsta.

148. insanit. $C_{p}$. i. 118, semcl insanivimus omnes.

152. Cp. Hor. Od. iii. i. 5.6, 'regum timendorum in proprios greges, | reges in ipsos imperium est Iovis.'

156. Baldi: $\mathrm{cp}$. ii. 172.

ECLOGA VIII, RELIGIO.

Ille canit montes, rura hic campestria; nymphae Polluci visae laudes et festa canuntur.

The eighth Eclogue returns to the same subject as the seventh, and explains that the 'virgin' who appeared to Pollux was no nymph, but the Queen of Heaven, the 'Mater Tonantis' herself. It adds u list of the pastoral blessings which she can bestow, and gives a calendar of the days which are to be kept in her honor. The preliminary debate between an upland and a lowland shepherd is imitated in Spenser's July Aeglogue.

2. Virg. Ecl. viii. 15 (repeated, Geor. iii. 326), cum ros in tenera pecori gratissimus herba; Geor. i. 312, mollior aestas.

3. deducere. $\mathrm{Cp}$. Livy, i. 18. 6, deductus in arcem.

4. longe prospicio. Cp. ii. 6r, longis... prospectibus.

9-11. In the Bologna edition of the collected poems, 1502, the passage is rewritten: versatus lutrae in morem limosa per arva, halat ubi cimex Stygiae excrementa lacunae, | est ubi ranarum, pulicum, culicum, fulicarum | patria, per salices, etc. This revision gets rid of the false quantity cimicum, but still retains the pülicum.

16-18. Burton, Anatomy of Mclancholy, ii. 4. I. 2 (quoting Leander Albertus), 'Baldus, a mountain near the lake Benacus, in the territory of Verona, to which all the herbalists in the Country continually flock.' melampodion. Cp. Plin. $N$. II. xxv. 5. 21, 'Melampodis fama divinationis artious nota est. ab hoc appellatur unum hellebori genus Melampodion. aliqui pastorem eodem nomine invenisse tradunt, capras purgari pasto illo animadvertentem.'

18. Valsasinus: from the Val Sassina, on the east of Lake Como.

20. Cp. Virg. Ecl. iii. 107, et Phyllida solus habito.

23. pingue polenta: cp. vi. 5, polenta coquit.

25. callosa: cp. iii. 25, ut manus incalluit. and Mantuan's 3 Parthen. fol. 147, duroque manus callosa lahori. The word is cited four times from St. Jerome : e. g. E.pist. 106. 1, callosa tencndo capu- 
Imm manus. Cp., also, Seneca, Dial. v. 17. 40 callosis... genibus manibusqus.

30. ferri. The earliest texts have the passive.

36. artifici ... manu. Cp. Ov. Met. xv. 218; Id. Am. iii. 2. 52; Prop. v. 2. 62, artifices... manus.

38-39. Cp. Virg. Ecl. i. 9-10, ille meas errare boves... permisit.

40. Cp. iii. 21, cotibus in duris; Virg. Ecl. viii. 43 duris in cotibus.

44. puto sidera tangant. Cp. i. 5o-I, credo ... concitet et ... tollat.

45.46. Mantuan reflects the common mediaeval tradition (based upon Ezekiel, xxviii. 13-16) which placed the Terrestrial Paradise on a lofty mountain in the far East. Cp. Claudius Marius Victor (5th cent.), In Genesim, 'Eoos aperit foelix qua terra recessus । editiore globo,' etc.; Alexander Neckam (d. 1227), De laudibus divinae sapientiac, "quid quod deliciis ornatus apex Paradisi | lunarem tangit vertice pene globum?' (quoted by Arturo Graf, Il mito del Paradiso terrestre, Turin, 1892, pp. 200, 210). Cp., also, Boccaccio, $E c l$. xiv. 170-2, 'est in secessu pecori mons invius aegro, I lumine perpetuo clarus, quo primus ab imis | insurgit terris Phoebus.' Dante placed it on the top of the mountain of Purgatory; Ariosto, on the mountain at the source of the Nile, Orl. Fur. xxxiii. st. 110 .

47. postea. The word here forms a dactyl; see, also, vii. 25.

49. Tonanti : see vii. $37 n$.

51. Carthusia: La Grande Chartreuse, near Grenoble, France.

52. Garganus : Monte Gargano, with a famous sanctuary of St. Michael. Athos: still the Holy Mountain, with its 22 convents. Laureta : Loreto, 15 miles south of Ancona. Cp. line 189, in sublime iugum. The house of the Blessed Virgin at Nazareth was conveyed by angels, first to the heights above Fiume (1291), then to the plain, and lastly (1295) to the hill, of Loreto. See U. Chevalier, NotreDame de Lorette, Paris, 1906. Laverna: La Verna (or, Alverna), in the Casentino, the 'rude rock between the Tiber and the Arno' (Dante, Par. xi. 106), where St. Francis of Assisi founded a monastery. Cp. Mantuan's De Sacris Diebus (of St. Francis' Day, Oct. 4), 'Umber erat, coluit Tuscae montana Lavernae, I quae furum tutela fuit.'

53. Soractis apex: cp. Virg. Aen. xi. 785, 'summe deum, sancti custos Soractis Apollo.' In Mantuan's day there was a monastery of S. Silvestro. Umbrosaque Vallis: Vallombrosa.

54. Nursini senis: St. Benedict, born at Nursia, a small town :1ear Spoleto, died at Monte Cassino.

55. Camaldula : Camaldoli, near Florence.

65. situosi : cp. v. 72, situs occupat ora, and Mantuan's Dionys. Areop., fol. 205, naufrag:o situosus et ora recenti.

67. sed quod inquis, etc. The same device is employed in Ecl. iv. 79-81, ' sed quod tam vafro memoras de virginis astr | rettulit in mentem,' etc. inquis : cp. v. 67 , vana inquis; $x .53$, ut Candidus inquit.

79. Tonantis: $\mathrm{cp}$. vii. 37 , Tonantem.

81. Virg. Geor. i. 17, alma Ceres.

82. Virg. Aen. i. 52-54, Aeolus antro | luctantes ventos... frenat.

85-86. A pocal. xii. 1, "mulier amicta sole, et luna sub pedibus eius, et in capite eius corona stellarum duodecim' (Asc.). 
93. Hor. Od. i. 5. 13-14, tabula sacer | votiva paries.

95. ista refers to what follows, as at iii. 122. Cp. the excuse for forgetting at vii. $23-24$.

98-101. Tibull. I.' 2. 49-50, 'cum libet, h.sec tristi depellit nubila caelo, I cum libet, aestivo convocat orbe nives:' Ovid, Am, I, 8. 9.10, 'cum voluit, toto glomerantur nubila caelo: / cum volult, puro fulget in orbe dies.'

102. modo = nunc, as at line 114 and 1,4 ,

104-7. Cp. Virg. Geor. i. 335-6, 'sidera serva, / frigida Satwrni sese quo stella receptet,' etc., and the comment of Servius: 'Saturnus deus pluviarum est... hic autem in capricorno facit gravissimas pluvias, et praecipue in Italia... in scorpio grandines, item in alio fulmina, in alio ventos.'

10. Virg. Ecl. vii. 36, si fetura gregem suppleverit.

116. 'capellas = capras cereas' (Asc.).

117. Ianni hircum. See iv. $30 \mathrm{ff}$.

123-4. Cp. Ser. Samm. Med. Chap. 58, 'praeterea si forte premit strix atra puellos / virosa immulgens exsertis ubera labris;' Perotti, Corn., fol. 254, 'maleficae mulieres quae noctu gradientes infantium corpora sanguine sugendo exhauriunt.'

126. Virg. Gcor. i. 325, sala laela.

129. Colun. x. 415, pingues mariscas.

137. Virg. Ecl. ix. 45, numeros memini, si verba tenerem.

141. campe. Perotti, Corn., fol. 117, "vermiculus est hortenses

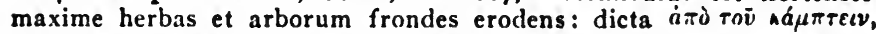
quod est flectere. unde Columella: 'nec solum teneras audent erodere froncles | implicitus conchae limax hirsutaque campe." "

144. Virg. Gior. iii. 148, oestrum Graii vertere vocantes.

145. anginoso: for the quantity, cp. Ser. Samm., 16, 'verum angina sibi.mixtum sale poscit acetum.' pubes... rustica: cp. Virg. Geor. i. 343, pubes agrestis.

154. C p. Catull. 64. 23I, memori tibi condita corde; Virg. Aen. is. 388 , tu condita mente tencto.

157. pietate : $\mathrm{cp}$. vi. 193, nostra etiam pielas pielate potcntior urbis.

158. Virg. Aen. i. 600, grales persolvere dignas; Ib. ii. 537, persolvant grales diguas.

162. commissa piacula solvunt. Cp. Virg. Aen. vi. 569, commissa piacula; Tac. Ann. i. 30. 3, soluti piaculo (where piaculo seems to mean 'guilt'); Prud. Apoth. 543-4. 'Christique negati | sanguine respersus commissa piacula solvit,' and Mantuan's I Parthen. Bk. ii, 'iam Deus antiquae commissa piacula fraudis I ponet' (ed Ascensius, 1513, fol. 59).

166. Cp. Virg. Geor. i. 308-10, 'auritosque sequi lepores...cum nix alta iacet.'

167. nonas Kalendas $=K$ alendas Novembris (by the old Roman reckuning).

170. Varro, $R$. $R$. ii. 1. 19, 'dicuntur agni cordi qui post tempus nascuntur ac remanserunt in volvis intimis.'

175. Cp. viii. 20, tradidit et dixit.

177-80. The Assumption of the Blessed Virgin, Aug. 15. Molorchaeo...ab astro: 'id est, a leone clava Molorchi interempto. est 
autem longe petitum epithetum' (Asc.). The epithet is fonnd also in Palingenius, Zodiacus Vitae, ii. 234 (Basel ed. 1548, p. 18): - tunc quum per torva leonis / signa Molorchaei gradiens calidissimus est sol.' transiit ad Superos: cp. ii. 146, tranabit ad aethera.

182. The Nativity of the Blessed Virgin, Sept. 8.

187. Lauretica: of Loreto. See note on line 52.

190. Thesallicas..., sagittas $=$ Sagifrarius. Cp. line 194, semi. Jeri... Chirenis.

192. 'The J'resentation, or entrance of the Virgin Mary into the tomple, Nov, ar.

197. The Conception of the Blessed Virgin, Dec. 8.

199-200. primordia ... fecit: cp. vii. 9, iaciens primordia. Here, and in another of his earlier poems (I Parthen. i. 223 ff.), Mantuan affirms the immaculate conception of the Blessed Virgin. In one of his latest poems, De Sacris Diebus, Bk. xii ("De conceptione Beatae Virginis Mariae') he deprecated the violent controversies which raged about the question, and dismissed it as unessential: 'aequanimes autem volumus si vera fateri, I vanus uterque labor, pietas temeraria, praeceps / religio. levitas velata scientiae amictu; nec natura potest illuc extendere visum, I nec Deus hoc docuit, nec re dependet ab ista / nostra salus. quae nos igitur dementia torquet ut studeamus in his consunere litibus annos? /...ergo nec infectam dicas, nec labe carentem. | obmutesce; Deus sciri haec arcana negavit.' The Blessed Virgin's immunity from original sin became an accepted dogma in 1854, by proclamation of Pope Pius IX.

201. Virg. Aen. iv. 6, Phoebea...lampade.

204. Cp. Ov. F. iii. 418, turaque pone focis.

205. The Purification, or the Presentation of Christ in the temple, Feb. 2 ('Candlemas').

207. Virg. Geor. ii. 330, Zephyrique topentibus auris; Ib. i. 217, candidus auratis aperit cum cornibus annum, etc.

209. Paranymphus. In the 'Apologeticon' prefixed to his First Parthenice Mantuan defended his use of this word: 'legant Augustini de Christi nativitate sermones... invenient angelum ad virginem missum paralymphum vocari.' It is used in the same way in a poem formerly attributed to Venantius Fortunatus (see Leo's ed., Berlin, 1881, p. 379).

210. The Annunciation, Mar. 25.

217. The Visitation, July 2. 'hospita, sc. Maria, redit a matre, sc. Ioannis' (Asc.).

2 :o. geminae...matri. Cp. Mantuan's poem De Sacris Diebus ('De Visitatione '), 'o geminae matres, quae pignora tanta tulistis.'

222. militiam caeli : trop. of the heavenly bodies, as in Acts, vii. 42, et tradidit eos servire militiae coeli; Deut. xvii. 3, et adorent eos...et omnem militiam coeli. 


\section{ECLOGA IX, FALCO.}

\section{Faustulus expertus Romani frigida tractus Pascua, pastorum mores exponit iniguos.}

The ninth Eclogue is a satire on the ways of the Roman curia, and doubtless reflects some of Mantuan's own experiences when he went to Rome on the business of his order. For similar criticism of the state of things at Rome, cp. De Calamitatibus, Bk. iii, 'venalia nobis | templa, sacerdotes, altaria, sacra, coronae, | ignes, tura, preces; caelum est venale Deusque' (Ascensius' ed., Paris, 1513, fol. 6r) ; Alfonsus, I3k. vi, 'pastores odere pecus nec pascere curant, I sed tondere greges pecorique illudere tonso' (Bologna ed., 1502, fol. 309); De Sacris Diebus ('De Sanctis Leonibus'), 'Romana gravi maculata veneno / curia, quae spargit terras contagia in omnes.' This eclogue had the fortune to be taken over into Protestant England, and there made the model of an attack on the "loose living of Popish prelates' in general. For it is imitated rather closely in the September A'glogue of Spenser's Shepheards Calender, wherein - Diggon Davie is devised to be a shepheard that, in hope of more gayne, drove his sheepe into a far countrye. The abuses whereof, and loose living of Popish pielates,... he discourseth at large.' And it was probably in Milton's mind when he wrote the passage in Lycidas about 'our corrupted clergy.'

\section{Cp. Livy, i. I. I, vetusti iure hospitii.}

19. Cp. i. I, gelida quando pecus omne sub umbra | ruminat.

20. parum: cp. line 39, quiescat obba parum; also the mediaeval use of unum parum (quoted by Du Cange from a document of the year 1308): "Vade, dixi ego, mecum unum parum;.libenter, dixit ipse.' The poet's brother Tolomeo defended a similar use of parum by citing Lucan, iv. 742, fraude sua cessere parum (Apologia, Lyons ed., 1516, fol. Ee, vii). recreabere potu: 'invitat autem ad potandum, nec abnuit Candidus, ut si qua petulantius in curiam Romanam dicta sint, a potis dicta censeantur' (Asc.).

31. Oenophili : the name occurs in Ecl. i. 161.

35-37. Cp. Ovid, Met. xii. 156, vinoque lez'ant curasque sitimque; Tibull. i. 2. I, adde merum vinoque novos compesce dolores. cardiaco. Cp. Plin. N. H. xxiii. 25. 50, 'cardiacorum morbo unicam spem hanc e vino esse certum est;' also, Seneca, $E p$. xv. 3; Cels. iii. 19; Juv. v. 32. In the later medical writers (Cael. Aur., Cass. Fel.) the word is used of disease of the heart, not of the stomach. Here cardiaco dolori seems to mean grief, sorrow (cordolium).

4I. Virg. Ecl. viii. 43, duris in cotibus.

42. Virg. Geor. i. I45, labor... improbus.

50-52. Cp. Virg. ix. 15, 'ante sinistra cava monuisset ab ilice cornix;' Hor. Od. iii. 27. 15-16, 'teque nec laevus vetet ire picus I nec vaga cornix.' tegetis. Du Cange quotes this word from Joannes de Janua (1286): 'Teges, parva domus quae et Tugurium, scilicet casula quam faciunt sibi custodes vinearum vel pastores ad tegmen sui; quasi Tegerium vel Tugurium.' Cp. Ercole Strozzi (of 
the Nativity), 'nascitur ille Puer tegetis sub culmine parvo / regales referunt cui pia dona manus,' Aldine ed., 1513, p. 7.

52. Virg. Geor. i. 410, corvi presso... gutture.

57. Cp. i. 27, pastu rediens.

65. Virg. Geor. ii. 198, texendae saepes etiam; Ib. iv. 34, lento ... alvaria vimine texta.

- 67-70. Virg. Ecl. i. 53-59, 'frigus captabis opacum...saepe levi somnum suadebit inire susurro... nec gemere aëria cessabit turtur ab ulmo;' Ecl. ii. 13, 'resonant arbusta cicadis.'

71. Cp. i. 92, hic tremulas inter frondes immurmurat aura.

73. Virg. Geor. ii. 527, ipse dies agitat festos fususque per herbam, etc.; Ecl. i. 1, recubans sub tegmine fagi.

74. Virg. Geor. ii. 526, adversis luctantur cornibus haedi.

77. Virg. Ecl. iii. 92, qui legitis flores et humi nascentia fraga.

88. 'pensi (i. e. excogitati et deliberati) nihil (i. e. habens), omnia casu (i. e. faciens),' Asc. Cp. Mantuan's De Calam. Bk. i (of Anger), 'nil pensi, nil mentis habet.' So in a letter of Aeneas Silvius (1444), 'et quia inexpertus est, parum pensi habet.' Cp., further, Sallust, Cat. xii. 2, 'nihil pensi neque moderati habere.'

92-93. Cp. Tennyson's Locksley Hall, 'a sorrow's crown of sorrow is remembering happier things,' with its allusion to Dante, Inf. v. 121-3, 'Nessun maggior dolore, | Che ricordarsi del tempo felice | Nella miseria.' The sentiment is an ancient one: cp. Boethius, Phil. Cons. ii. prosa 4, 'nam in omni adversitate fortunae infelicissimum est genus infortunii fuisse felicem,' Euripides, Iph. Taur. 1121,

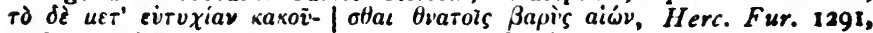

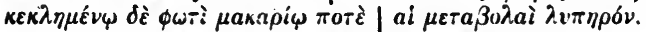

94. Virg. Geor. ii. 434, humilesque genistae.

95. malus ... punica: 'pomegranate'. Cp. Ov. Met. v. 536, puniceum... pomum.

96. săbūco. Andreas Vaurentinus, in his commentary on this passage, suggested that this form of the word was due to metrical convenience. But Mantuan might have cited the authority of Ser. Samm. 50, vel tristia poma săbūci, an author whom he mentions in the Apologeticon prefixed to his First Parthenice (1481): 'Quintus Serenus et Ausonius, medici et poetae.' See, also, the note on anginoso, viii. 145.

100-1. Hor. Od. i. 4. 4, nec prata canis albicant pruinis; Virg. Ecl. ii. 10, rapido... aestu; Geor. iii. 479, totoque autumni incanduit aestu.

102-3. Cp. De Calam. i (the picture of Gastrimargia), 'sub gutture lato I surgit et inflatum tollit cutis uvida pectus;' Ib. ii (the address to Pope Sixtus), 'stent ad praesepia tauri | qui signata iugis longoque attrita labore | colla gerunt.'

104. Virg. Geor. iii. 81, luxuriatque toris animosum pectus.

107. cui. Ioannes Murmellius defended this irregularity by citing Sallust, Cat. 56. 5, 'interea servitia repudiabat, cuius initio ad eum magnae copiae concurrebant,' and Tibullus, ii. 1. 11-12, 'vos quoque abesse procul iubeo, discedite ab aris, | cui tulit hesterna gaudia nocte Venus' (Letter to Paulus Ruremundensis, quoted in the Deventer edition of the Eclogues, 1510 ). 'Ita et hic, cui <subintellige> gregi 
armentorum, vel armento.' [The edition of Tibullus 'cum commentariis Bernardini Veronensis,' Brescia, 1486, gives the text as Murmellius quotes it; modern editions have discedat ab aris.] Cp., also, Calpurnins, Ecl. i. 27, longa ... internodia.

119. appropias. Mantuan's defence of this word is quoted in his brother Tolomeo's Apologia (Lyons ed., 1516, fol. Gg): 'usurpat similiter hoc verbum appropio, id est, appropinquo, deductum a prope, sicut elongo a longe. reperitur id verbum, ut inquit poeta, fuisse in usu ante annos abhinc nille. legitur enim in editione valgata psalmorum quae Hieronymum antecessit $d u m$ appropiant super me nocentes.' The word occurs a dozen times in the Vulgate, and the 'Itala' often uses it where the Vulgate ha: appropinquare; see H. Rönsch, Itala und Vulgata, p. I81.

122. a longe $=e$ longinquo. For such combinations of preposition and adverb, see Rönsch, Itala und Vulgata, pp. 23I-4, 475. So Augustine, Conf. iii. 3. 5, has, 'et circumvolabat super me fidelis a longe nisericordia tua.'

127. illequeat. Prud. Cath. iii. 4I, 'callidus illaqueat volucres I aut pedicis dolus aut maculis, | illita glutine corticeo | vimina plumigeram seriem | impediunt et abire vetant.'

128. Virg. Geor. ii. 396, in veribus torrebimus exta colurnis.

133. Calpurn. i. 7, defendimus ora galero.

136-7. Virg. Geor. iii. 420, cape saxa manu, cape robora, pastor.

138-9. spineta colubris | plena: cp. Virg. Geor. iv. 243, congesta cubilia blattis.

140. Virg. Geor. iii. 434, asperque siti atque exterritus aestu.

142. Virg. Geor. iv. 554, subitum ac dictu mirabile monstrum; Aen. vii. 680, subitum dictuque oritur mirabile monstrum.

143-5. Virg. Ecl. viii. 97-99, his ego saepe lupum fieri, etc. madere caede: cp. Ov. Met. i. 149 and xiv. 199, caede madentes; xiii. 388 , caede madebit.

147. obviat: cp. Ital. ovviare. Virg. Aen. ii. 535, pro talibus ausis.

153-4. The animal worship of the ancient Egyptians is often mentioned: Cic. N. D. iii. 19, Tusc. Disp. v. 27. 78; Juv. xv. 1-8; Arnob. i. 28; Cels. Epicur. ap. Orig. iii, etc.

158. Gen. i. 28, 'dominamini ... universis animantibus quae moventur super terram' (Asc.).

159. Virg. Aen. iii. 139, letifer annus.

162. Virg. Geor. iii. 515, duro fumans sub vomere taurus I concidit.

163. Petrarch, Ecl. vi. 73, nec morbi modus ullus adest.

168. opulescunt. Gellius reports, xviii. I1. 3, that Furius Antias was criticized for using such words as opulescere (=opulentum fieri).

174-7. Cp. Virg. Geor. iii. 343-5, 'omnia secum / armentarius Afer agit, tectumque laremque | armaque,' stc. căcăbos: Teofilo Folengo has căcăbi (Venice ed., 1555, fol. 16).

185-191. Cp. ii. 87-88, 'quam melius fuerat... rediisse... servasse,' etc.

188. Athesis: the Adige.

190. Abdua: the Addua. 
193-5. Cp. vi. 124-6, 'vidi etiam patres...dum segnes dormire volunt .... prostituisse', etc.

199-200. Cp. Dante, Par. xvi. 73, 'Se tu riguardi Luni ed Urbisaglia | Come son ite,' etc.; also, Petrarch, Fam. v. 3, 'Lnnam olim famosam potentemque, nunc nudum et inane nomen' (ed. Fracassetti, i. 254). Luna: famous in antiquity for its harbor (the Gulf of Spezia); destroyed by the Arabs in 1016. Hadria: an ancient seaport between the Po and the Adige; ruined by a war with Venice in 1017. Salvia: Urbs Salvia, or Urbesalvia (whence the modern name Urbisaglia), an inland town in Picenum. Under the Empire it was a place of some commercial importance, but it was completely destroyed by Alaric. Umber: see iv. 8I $n$.

202. $\operatorname{modo}=$ nunc. See i. 4 n.

210. Cp. Virg. Ecl. i. 75, ite meae, felix quondam pecus, ite capellae.

211. Juv. v. 10, tam ieiuna fames; Ov. Met. viii. 782, ieiuna Fames.

213. pastor. Falcone de' Sinibaldi, papal treasurer under Innocent VIII. From him Mantuan received much assistance, when he went to Rome on the business of his order: 'cuius beneficio ex omnibus periculis est liberatus.' See pp. 15 and 28.

214. Virg. Ecl. ii. 20, quam dives pecoris; Aen. i. 343, and iii. 642, ditissimus agri; so Ovid, Mct. v. 129 .

218. Macram. Cp. Dante, Par. ix. 89, 'Macra che per cammin corto | Lo Genovese parte dal Toscano.'

219. Cp. Virg. Ecl. v. 16-17, 'lenta salix quantum pallenti cedit olivae, | puniceis humilis quantum saliunca rosetis,' etc.; Ib. i. 26, 'quantum lenta solent inter viburna cupressi.'

220. Tityrus means Virgil, as at ii. 9 .

221. Virg. Ecl. i. 43-4, quotannis | bis senos cui nostra dies altaria fumant. fumare... fecit: see v. $58 n$.

230. Virg. Aen. i. 78-9, tu sceptra Iovemque | concilias.

\section{ECLOGA X, BEMBUS.}

Nunc verae et falsae discrimina relligionis Narrat, ovesque pias Carmeli separat hoedis.

The tenth Eclogue is a debate between the two great divisions of Mantuan's order, the Observantes, or Discalced Carmelites, and the Conventuals, who followed a mitigated rule. The speakers discuss the abuses which had crept into the order and caused the separation, and the umpire advises a return to the good old ways.

I. Bembe. The name of the umpire (and the title of the poem) is probably chosen out of compliment to Bernardo Bembo, of Venice, to whom Mantuan dedicated the Second Parthenice (c. 1488).

3. Batrachus... Myrmix. Ascensius saw a certain fitness in the two names. 'Nam fátpayos rana dicitur, cui fere similem habent Carmelitae de observatione interiorem tunicam, quia piceam aut, ut dicunt, griseam; Myrmix autem formica, quae nigra est, at non 
observantium tunica.' There is a similar pair of names in $E c l$. vi, Cornix and Fulica. The name Batracos had been given to one of the speakers in Boccaccio's ninth Eclogue; the name Myrmix is employed again in the second and fifth Eclogues of C. Erasmus Laetus (Witebergae, anno 1560).

6-7. Cp. the aged Meliboeus in Nemes. Ecl. i. 52-53, 'tn ruricolum discernere lites assueras, varias pacans mulcendo querellas;' Virg. Ecl. iii. 108, tantas componere lites.

10. Eurotae campos. Cp. Virg. Ecl. vi. 82-83, 'omnia quae Phoebo quondam meditante beatus | audiit Eurotas iussitque ediscere lauros.'

11. Virg. Ecl. iii. 62, 'Phoebo sua semper apud me / munera sunt, lauri,' etc.; Ovid, Mei. xi. I65, 'ille caput flavum lauro Parnaside vinctus.'

13-14. Virg. Ecl. iii. 55, dicite, quandoquidem, etc.; Pers. vi. I, admovit iam bruma foco te, Basse, Sabino?

16-17. Cp. vi. 1-2, a culmine pendet | stiria.

20-21. Virg. Geor. i. 259, frigidus agricolam si quando continet imber.

29. Cp. Virg. Geor. ii. 184, pinguis humus dulcique uligine laeta.

34. Juvencus, i. 414, Galilaea per arva; so Sedulius, iv. 188.

35. lacu... magno: the Lacus Samachon:tis (Waters of Merom).

36. mare... apertum: "the sea of Galilce, which is the sea of Tiberias' (John, vi. I).

39. Asphalti gurgitis: the Lacus Asphaltites, or Dead Sea. infames... undas : cp. De Calam. i (of Luxuria), 'haec fera adulterium parit incestusque nefandos | stupraque et igne scelus dignum quo barbara quondam | abstulit immixtis sulfur quinquurbia flammis; I nunc lacus est ubi tunc homines errare solebant,' etc.

54. Elias. 'The Carmelite Order claimed for its founders the prophets Elijah and Elisha. Mantuan often repeats the claim: De Vita Beata; I Parthen. Bk. iii; De Patientia, ii. 27, iii. 31; Aifonsus, Bk. v; Apologia pro Carmelitis. The first volume of the Annales Carmelitarum by Ioan. Bapt. de Lezana (Rome, 1645) begins with 'annus mundi 3123 , ante Christum 930.'

59. Cp. vii. 130-1, sicut de fonte perenni fumina; Ronsard (QEuvres, ed. Blanchemain, vii. 128), Vos estes mes ruisseaux, je suis vostre fonteine.

66. fas est $=$ licet. Cp. vii. 80-81, sed fas mihi flere, quod illi i non licet.

68. Cp. ix. 159, pestifer annus; Virg. Aen. iii. 139, letifer annus.

69. omisit: cp. ii. 5, omissa. In the Bologna edition of the collected poems, 1502, the line is rewritten: signa dedit, nil quod tangat magalia omisit.

77. Virg. Geor. iv. 126, umectat flaventia culta Gaiaesus.

79-81. Virg. Geor. ii. 112-13, apertos | Bacchus amat colles, Aquilonem et frigora taxi.

87. Cp. Hor. Od. ii. 14. 15-16, nocentem | corporibus metuemus Austrum.

89. Cp. Virg. Geor. ii. 146, hinc albi, Clitumne, greges; Prop. iii. 19. 26, et niveos abluit unda boves; Sil. Ital. iv. 546; Stat. Silv. i. 4. 129. 
91. Lucr. iii. 318, unde haec oritur variantia rerum.

99. Virg. Geor. i. 272, balantumque gregem Auvio mersare salubri; Ib. iii. 446-7, udisque aries in gurgite villis | mersatur.

I01. Virg. Geor. iii. 444, hirsuti secwerunt corpora vepres.

102-3. Virg. Geor. iii. 44I, turpis oves temptat scabies; Mart. i. 78. I-2, indignas premeret pestis cum tabida fauces | inque ipsos vultus serperet atra lues.

104-5. Virg. Geor. iii. 481, corrupitque lacus, infecit pabula tabo.

106-9. The correct color of the Carmelite habit has often been the subject of animated discussion among the different branches of the order. Mantuan himself regarded it as a matter of mach importance. In his first term as Vicar-general he came into conflict with the General of the order, who had prescribed 'nigrum in vestibus colorem;' and he obtained from Sixtus IV a special bull which permitted the Congregation of Mantua to wear 'habitum grisei coloris, sive tanè' (tan color). In the third book of the $D e$ Calamitatibus he records that the founder of the order, the prophet Elias, wore, and prescribed for his followers, a garment of 'natural wool': 'namque rudem tunicam tetrae fuliginis instar, | cri simplex expersque artis natura colorem | fecerat, induitur; per saecula cuncta nepotum | progenies iussit similem gestaret amictum.'

109. Cp. Livy, xxxvii. 54. I8, 'nec terra mutata mutavit genus aut mores.'

125. Virg. Ecl. iii. 7, parcius ista viris tamen obicienda memento.

127. Virg. Ecl. viii. 41, ut me malus abstulit error.

128. Virg. Ecl. iii. 51 , ne quemquam voce lacessas.

130. $\mathrm{Cp}$. ii. 4 , et tumidis ripas aequaverat undis.

132. saepierant. Neue cites the form sepivit from St. Jerome, In Ies. v. 2.

135. Virg. Geor. i. 244, flexu sinuoso elabitur Anguis.

137. Virg. Geor. i. 264, furcasque bicornes; Ovid, Met. viii. 637, furca... bicorni.

138. Virg. Aen. ii. 475, linguis micat ore trisulcis.

143-4. grege diviso. An allusion to the disruption of the Carmelite Order in 1459, when the Observantes, or Discalced Carmelites separated from the Conventuals and went back to more rigid rule.

146. Aurora. Cp. line 73, ad ortum.

152. pedum...septem. An allusion to the separate cells in which the early Carmelites lived; 'tantum enim spatii cellis singulis congruit' (Asc.).

153. Cp. v. 16, mapalia saepe | cingere.

175-6. eremum...deserta. The early Carmelites were hermits. Batrachus means that the Reformed body is not even yet close enough to the old rigid rule.

180. cuium pecus: 'dictum id puto pro cuiumcuinm, id est, cuiuscumque pecus' (Asc.). Cp. Virg. Ecl. iii. I, cuium pecus.

182-5. Cp. Seneca, Dial. v. 26. 3, non est Aethiopis inter suos insignitus color; Juv. ii. 2. 23, loripedem rectus derideat, Aethiopem albus:

185. Virg. Ecl. iii. 101, pecori pecorisque magistro. 
:

$\checkmark$

$\checkmark$ 


\section{INDEX}

The references in Arabic mumerals are to the pages of this book Such references as iv. 167 mean the number and liwe of one of the Eclogmes.

ab sevo, vi. 132.

Abdua, ix, 190, 218

Adam, vi 68.

Adulescentia, 62

Aeneas Silvius, 123, 132

Ainsworth's Lativ Dictioness, 33 .

Aleiitia, \#.

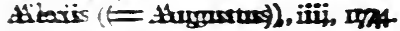

Ailex. P. 珐. IT.

dimaragia, Flarida, 125, 15,155 . 15.

24, $25,32,33,15^{6}$

Ancilecta Bullerdivera $3 a$

Andreas Vaurentines, 36. 126.

$130,147$.

ant, wisdom of, r. 36-38.

Antonius Sabinus, 29.

d'Arco, 18.

Arienti, G. Sabadino degli, $I x_{\text {, }}$

$14,16,23,27,28,31$.

Arrivabene, G. P., 26.

Arx, S. von, 11, 16, 23.

Ascensius, 16, 20, 27, 32, 35, 36, $44,58,124,125,126,130,131$. $132,133,138,139,140,141$, $143,144,145,146,147,148$, 149, 151.

Athesis, ix. 188.

Athos, viii. 52.

Badius, Iodocus, 32, 36, 44; see Ascensius.

Baldus, il. 172, vil, 156, vili, 16.

Banclello, Mlatteo, 17, 42, 121.

Banclollus, Mattheus, C. ordinis prae.', 29.

Barbaro, Ermolao, $24,26$.

Barclay, A., 45, 48, 49, 134, 136, $138,139,140$.

Basse, W., 43.

Baveria, Filippo, 14, 23.

Baynes, T. S., 38, 39.
Beaumont and Pletcher, 44

Pebel, $\mathrm{H}_{2}$, 45 .

Bembo, B, 26, 149

Pembes, $x$ I.

Penacus, ii 58, 62

Bentivoglio, A, 23 .

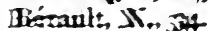

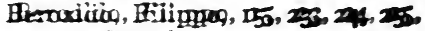
25. 35. 15 .

Bettineili, S, $1 \%$

Bocsaccio, 131, 124, 135 . 133 $141,143,143,159$

Boswell, J. 45.

Bright, J. W., 42, 52

Brink, B. ten, 49

Brome, R., 43.

Brunet, G., 36.

Brunet, J. C., 35.

Bureau, Laurent, 32.

Burton, R., 44, 45.

Caecias, iv. 219

Calpurnius (imitated), 58

Camaldula, viii, 55.

Cambridge History of Enclish Literalure, 50.

Carafa, Oliviero, 14, I5, 24

Carbo, ii, 154.

Carmelite habit, 149, 151; founder of the order, $x_{0} 54$.

Cinrmelus, vii, 120, $x_{1}, 50,70$

Carrolus, Iafredus, as.

Carthuxia, vili. 5 t.

Castiglione, B., 21, 22.

Catholic Encyclopedia, 17, 23.

Cecco d' Ascoli, 133.

Coresara, Paride, 23, 26, 62, 1ax.

Chevalier, U., 15, 24.

Cholières, N. de, 27.

Christian Remembrancer, 33.

clipeum Minervae, v. 98. 
Codri supellex, v. I04.

Coitus, ii. 37.

Colet, J., 16, 37.

Comparetti, D., 130.

Congregation of Mantua, 13, 140 15.

Coroneus, Ioannes, 36.

Correggio, Niccold da, 22.

Cortese, Alessandro, 24.

Coryat's Crudities, 32.

Cosmas, iii. 46.

Cosmus, v. 96.

Crepundia Poetica, 47.

crocodile's tears, iv. 196.

Curtius, Benedictus, 48.

Davari, S., 19, 20, 21, 22, 30.

Delaruelle, L., 34, 131.

Despautères, J., 33.

des Periers, B., 40.

Dictionary of National Biograpliy, 49.

Donesmondi, F. Ippol., 30, 38.

Nrayt :., M., 40, 43, 44.

'E. K.,' 46, 50, 134.

Elias, $x .54,65$.

Eobanus Hessus, 33, 52, 53.

Epistolae Obscurorum Virorum, 33.

Equicola, Mario, 20, 23, 42, 48.

Erasmus, 31.

Este, Isabella d', 11, 16, 20, 22.

Euricius Cordus, 47, 54, 55, 132.

Eva, iv. 170, vi. 57 f.

facil experientin cautos, $i x .195 .^{*}$

Falco, ix. 213; see Sinibaldi.

Fantuzsi, Ant., 23.

Fanucchi, L. G., 17.

Farnaby, T., 39.

Fauste, precor, gelida, II, 39, 40 ; i. I.

femineum servile genus, 4t, 47 ; iv. 110.

Fiera, Bunt., 23, 31.

Folengo, Teofilo, 31, 39, 148.

fons et origo, vi. 246.

Fontenelle, 48, 122.

Fortuna noverca, vi. 30.

Foscarari, L., 12, 23.

Frati, L., 12, 13, 23.
Fucus, 51.

Furness, H. H., 27.

Gabotto, F., I1, 16, 17, 131.

Garganus, viii. 52.

Gaurico, Luca, 17, 121.

Geiger, L., 38.

Giraldi, L. G., 27, 32, 34 .

Gonzaga, Federico, 13, 19.

- Francesco, 19, 20, 22, 31.

- Isabella; see Isabella d'

Este.

- Lodovico, 19.

- Sigismondo, 22, 30. Tolomeo, 20, 30.

Googe, B., 50.

Gosson, S., 40.

Graesse, J. G. T., 35, 36.

Graf, Arturo, 143.

Gratius, Ortuinus, 33.

Greene, R., 40, 4I, 42, 5 I.

Greg, W. W., 45 .

Gregorio Tifernate, $11,12,126$, 130, 131 .

Guazzo, S., 57.

Guillaume le Clerc, 135.

Hadria, ix. 199.

Hain, L. F. T., 35, 36.

Hall, J., 42.

Harculus, iii. 4.

Harvey, G., 40, 41 .

Harvey, T., 45.

Hegius, Alex., 38.

Hernand y Aguilar, G., 29.

Ileywood, T., 44.

Honle, C., 39.

hyena's cunning, iv. 196.

immaculate conception, vili, 197200.

Innocent VIII, 14, $15,28$.

instar ovis, vil. 15.

Itnla, 136, 148.

Tericus, $x, 38$.

Jerome, St., 123, 133.

Innn. Bapt. de Lezana, IsO.

Johnson, Sam., 39, 45.

Iordanes, $x, 32$.

Tovius, Paulus, 18, 20, 26, 32.

Juan del Encina, 129. 
Julius II, 29.

Juvenal (imitated), 58.

Keller, O., 122.

Kluge, F., 50.

Knod, G., 37.

Krause, C., 53.

\section{Laelia, 123.}

Laetus, C. Erasmus, 14I, 150.

Laetus Pomponius, 24.

Lamentationes novae Obscurorum Reuchlinistarum, 46.

Lamp, Guilhelmus, 33.

Larivey, Pierre de, 44, 56.

Latini, Brunetto, $133,135$.

Laurent de la Gravière, 48.

Laureta, 15 ; viii. 52,187 .

Laverna, viii. 52.

Lee, Sidney, 44.

Leo X, 29.

Leonora d' Aragona, 16.

Leontorius, C., 16.

Lezana, Ioan. Bapt. de, 150.

Libanus, $x$. 34 .

Lockwood, D. P., 132.

Lodge, T., 40.

Löfstedt, E., 128.

ludit Amor sensus, i. 48.

Luna, ix. 199.

Lupton, J. H., 16, 37.

Luzio, A., 8, 17.

Luzio-Renier, I1, 16, 17, 20, $21,23,31,38,42,121$.

Machiavelli, Carforo, 26.

Macrn, ix. 218.

Maltei, Sclpio, 3 t.

Mingki, Costunza de', 20.

Munncorda, G., 54 .

Mantegna, A., 23.

Mnntua, Congregation of, $13,151$. Man'unn: 'good old M.', Iri

n 'Christinnus Maro', 318 'honest M.', 40: 'the homely Cormelite', 42; 'moral M.' 4.3; 'nome foul-mouth'd M.', 44; 'plaine M.', 44.

Munfuan Reform, 13, ist.

Mnrius, ii. 154.

Marsus, Petrus, 24.

Martinez de Toledo, 132,
Martyn, W., 44.

Marullus, 31.

Mckerrow, R. B., 42.

Melander, Otho, 47.

melior vigilantia somno, i. 5 .

Meres, Francis, 46.

Merlinus Cocaius, 31.

Merula, Giorgio, 11, 12, 26.

metre (Mantuan's), 59.

Michel d' Amboise, 48.

Middleton, T., 43.

Milton, 52.

Mincius, ii. 37, iii. 180, ix. 190.

Modover, Antonio, 18.

Modover, Pietro, 18.

Molorchaeus, viii. 177.

Monumenta Germanica Paedagogica, 37.

Morbioli, L., 28.

multotiens, i. 167 .

Muratori, L. A., 12.

Murmellius, Ioan., 35, 36, 38, 46. $121,129,137,147$.

Murrho, Seb., 16, $31,38$.

Mlustard, W. P., 48, 52.

Napens, Caesar, 13.

Nashe, 1., 4I, 42.

Niccolò da Correggio, 22.

Niceron, J. P., 20, 29.

Nicholson, S., 43.

nodus Herculis, v. 65 .

Nursinus, viii. 54 .

Observantes, 149, 151.

Oedipodes, 62.

Oenophilus, i. 86r, ix. 31 .

Ovid (imitated), $5 \%$

Palingenius, 38, 46, 123, 137, 145.

Paranymphus, viii. 209.

Pascal, C., 130.

Pasqualigo, L., 56, 132.

patinn Aesopi, v. 98.

Prodanlius, st.

lellechet, M., 35.

lerotti, N., 58, 122, 123, 124, $133,134,135,839,140,144$.

Peters, E.., 135 .

Petrarch, 58, 127.

Petrus Iucius, 32, 34.

Philippe de Thaün, 133, 135. 
Physiologus, 135.

Pico della Mirandola, 14, 15, 24, 25, 26.

(the Younger), 12, 16, 24, 25, 26.

Pietro da Novellara, 16, a2, 30.

Jolixiano, A., 24, 25, 26.

Pontano, G. G., 24, $13 x$.

I'rudentius (imitnted), 58.

I'uttenham, G., 46.

l'ythagorae mensae, v. 104.

Raffaello Sanzio, $2 x$.

Randolph, T., 42.

Refrigerio, G. B., 12, 13, 14, 23 , 27, 122.

Reissert, O., 48, 50.

Remundus Langano de alta Ripa, 36.

Return from Parnassus, 43.

Roberto da San Severino, 14, 28.

Rönsch, H., 123, 148.

Sabadino: see Arientl.

Salbie, F., 42, 51, 52, 121, 122, 140.

Salvia, ix. 200.

Sammonicus, Serenun, $144,147$.

Sasso, Panfilo, 26.

Saturnina fames, 62.

Scaliger, J. C., 34, 39.

semel insanivimus omnes, 40-46, 48,51 : i. I I8.

Servius, 129, 144.

Shakespeare, II, 40, 44.

Sina, viii. 53.

Sinibaldi, Falcone de', 14, 15, $23,28,149$.

Sixtus IV, 13, 14.

Smith, G. C. Moore, 5I, 123.

Solymus, ix. 224, x. 2.

Soracte, viii. 53 .

sorte tua contentus abi, v. 46 .

sortiri digitis, i. 24.

Spagnolo, Alessandro, 21, 22.

- Baptista, I I.

Pietro, 18, 19, 28.

Tolomeo, 12, 16, 18, 20, 21, $22,24,27,58,123,130,131$, $138,146,148$.
Spenser, E., 50, 134, 135, 136, $140,142,146$.

Strozzl, Ercole, 146.

Summern, W. C., 136 ,

antux (Mnntuan's), s9.

'l'uмmo, 'I', 56, 57.

'T'extur, Ruvinlun, 33, 38, 48, 5h,

Theodulun, tas.

'Thunsue, L., 32, 131.

Tilbullus, 57.

Tifornute, Grogorio, 18, 12, 126, $130,131$.

Tiraboschi, G., 18 .

Titan (= the Sun), vili. 177.

Tityrus (= Virgil), ii. 9, iil. 174 , v. 86, ix. 220.

Tobler, A., 130.

Tonans, vii. 37, viii. $49,79$.

Tonius, i. 163 .

Torrentinus, H., 33 .

Trithemius, 16, 26, 27, 32.

'Trivulzion, G. G., 28.

'l'urbervile, G., 45.

Vmber, 12, 58, 131.

Umbroma Vallin, vili, 53.

Valla, I., 13 I.

Valsasinus, viii, 18.

Ventimiglia, M., 16.

Victoria, $5 \mathrm{I}$.

Virgil (imitated); see Notes passim.

Vives, L., 33.

vocabulary (Mantuan's), 59.

Watson, F., 39.

Webbe, W., 46.

Wily Beguiled. 43.

Wimpfeling, J., 16, 17, 31, 36, 38,131 .

Wind scheid, K., 52.

Witt's Recreations, 44.

Wolf, T., Jr., 12, 16, 17, 26, 31, $36,37,131$.

woman's ways, iv. I10 ff.

Young's Latin Dictionary, 33. 





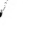




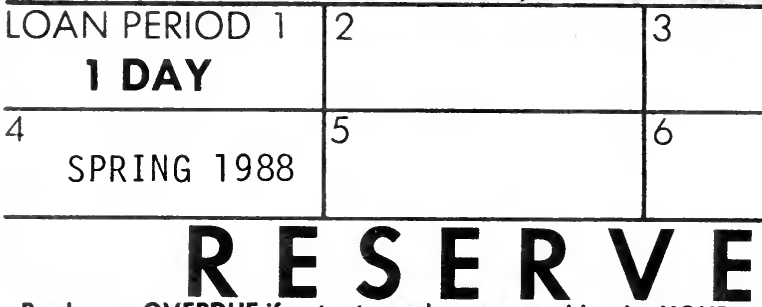

Books are OVERDUE if not refurned or renewed by the HOUR (where indicated)

2 HOUR books may not be renewed by telephone. Return only to HGS.

\section{DUE AS STAMPED BELOW}

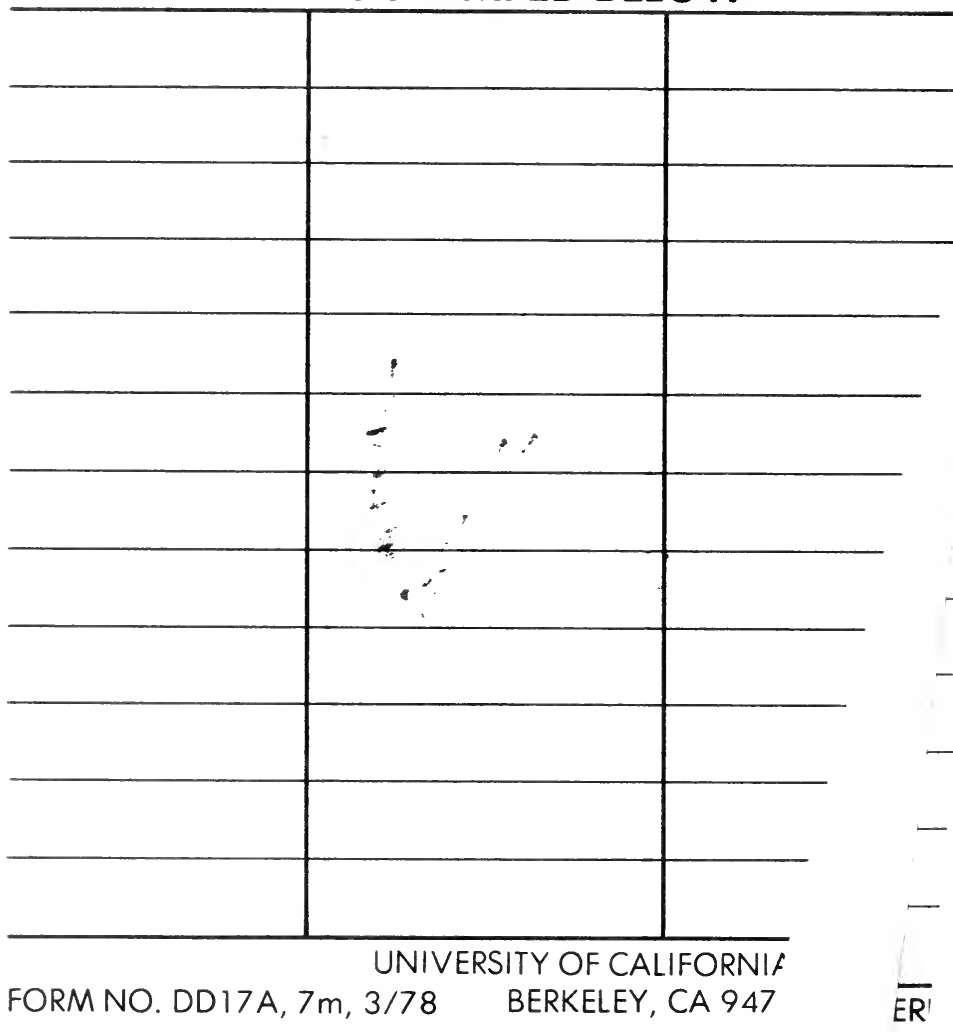


GENERAL LIBRARY - U.C. BERKELEY

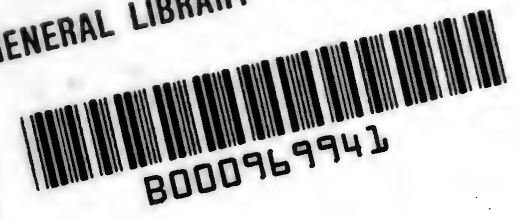


5 